\title{
Public Housing: A Tailored Approach to Energy Retrofits
}

J. Dentz, F. Conlin, D. Podorson, K. Alaigh, and T. Davis

Advanced Residential Integrated Energy Solutions Collaborative 


\section{NOTICE}

This report was prepared as an account of work sponsored by an agency of the United States government. Neither the United States government nor any agency thereof, nor any of their employees, subcontractors, or affiliated partners makes any warranty, express or implied, or assumes any legal liability or responsibility for the accuracy, completeness, or usefulness of any information, apparatus, product, or process disclosed, or represents that its use would not infringe privately owned rights. Reference herein to any specific commercial product, process, or service by trade name, trademark, manufacturer, or otherwise does not necessarily constitute or imply its endorsement, recommendation, or favoring by the United States government or any agency thereof. The views and opinions of authors expressed herein do not necessarily state or reflect those of the United States government or any agency thereof.

Available electronically at SciTech Connect http:/www.osti.gov/scitech

Available for a processing fee to U.S. Department of Energy and its contractors, in paper, from:

U.S. Department of Energy

Office of Scientific and Technical Information

P.O. Box 62

Oak Ridge, TN 37831-0062

OSTI http://www.osti.gov

Phone: 865.576 .8401

Fax: 865.576.5728

Email: reports@osti.gov

Available for sale to the public, in paper, from:

U.S. Department of Commerce

National Technical Information Service

5301 Shawnee Road

Alexandria, VA 22312

NTIS http://www.ntis.gov

Phone: 800.553 .6847 or 703.605 .6000

Fax: 703.605.6900

Email: orders@ntis.gov 


\title{
Public Housing: A Tailored Approach to Energy Retrofits
}

\author{
Prepared for: \\ The National Renewable Energy Laboratory \\ On behalf of the U.S. Department of Energy's Building America Program \\ Office of Energy Efficiency and Renewable Energy \\ 15013 Denver West Parkway \\ Golden, CO 80401 \\ NREL Contract No. DE-AC36-08GO28308 \\ Prepared by: \\ J. Dentz, F. Conlin, D. Podorson, K. Alaigh, and T. Davis \\ Advanced Residential Integrated Energy Solutions Collaborative \\ The Levy Partnership, Inc. \\ 1776 Broadway, Suite 2205 \\ New York, NY 10019 \\ NREL Technical Monitor: Stacey Rothgeb \\ Prepared under Subcontract No. KNDJ-0-40347-05
}

February 2016 
The work presented in this report does not represent performance of any product relative to regulated minimum efficiency requirements.

The laboratory and/or field sites used for this work are not certified rating test facilities. The conditions and methods under which products were characterized for this work differ from standard rating conditions, as described.

Because the methods and conditions differ, the reported results are not comparable to rated product performance and should only be used to estimate performance under the measured conditions. 


\section{Contents}

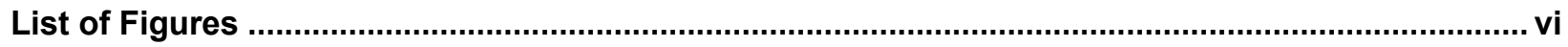

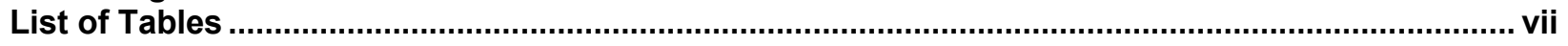

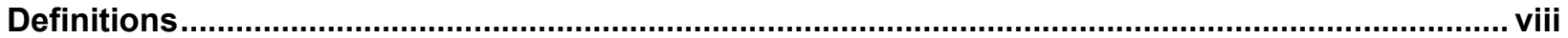

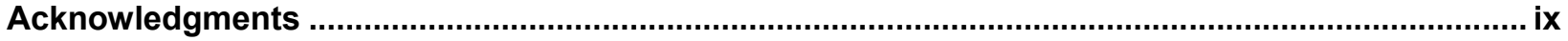

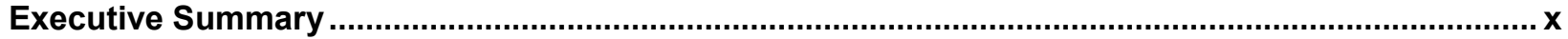

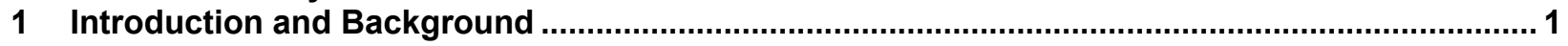

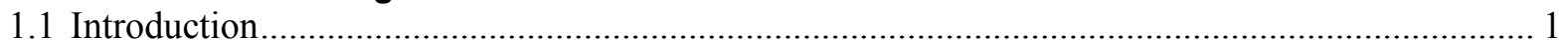

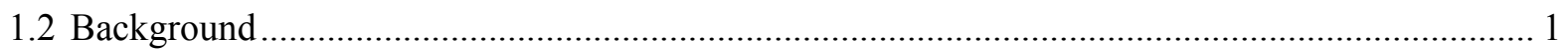

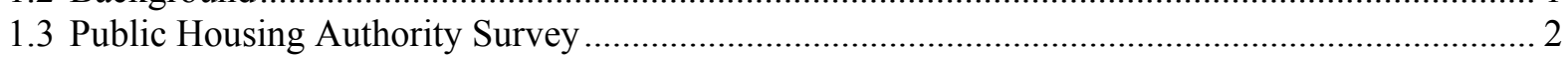

1.4 Relevance to Building America's Goals .............................................................................. 3

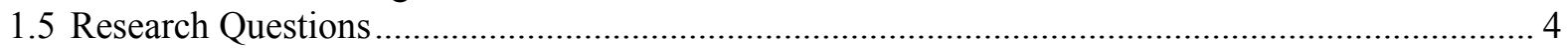

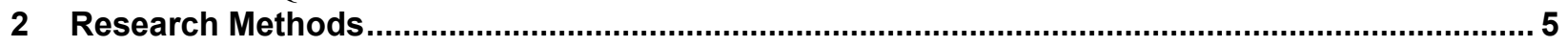

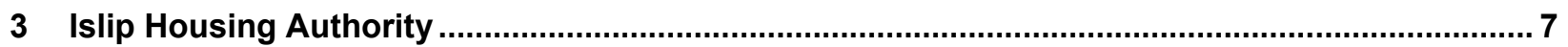

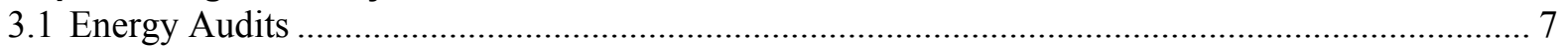

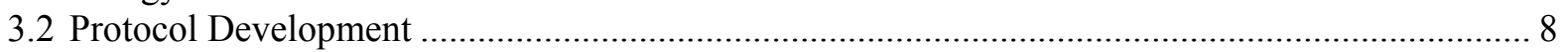

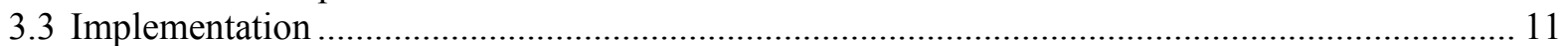

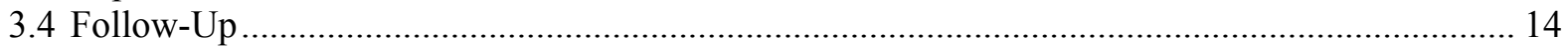

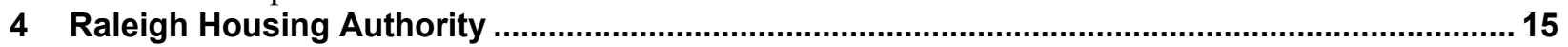

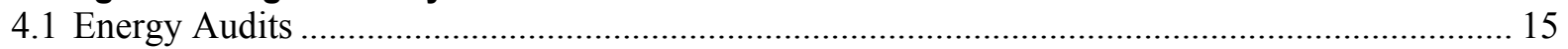

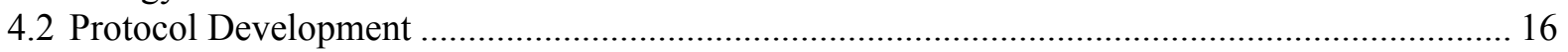

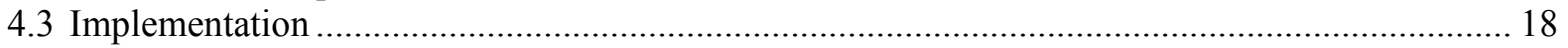

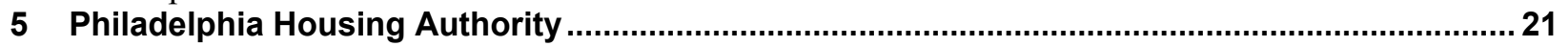

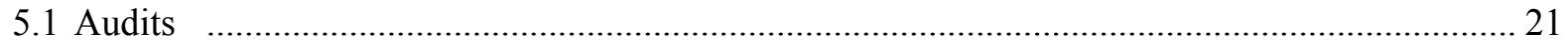

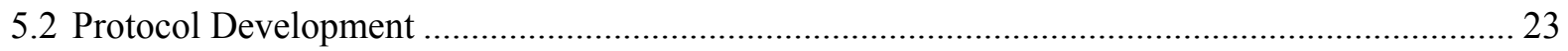

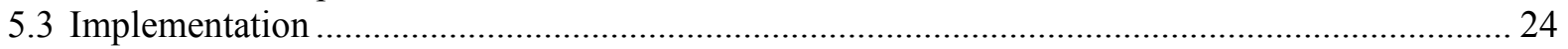

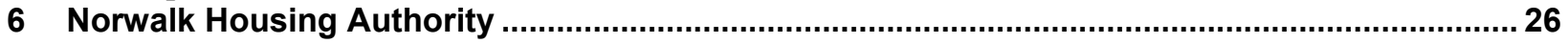

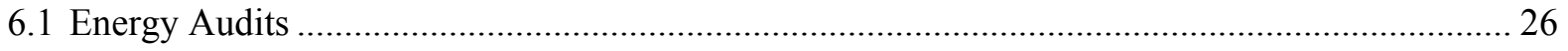

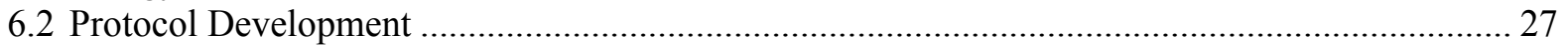

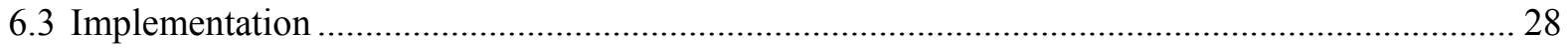

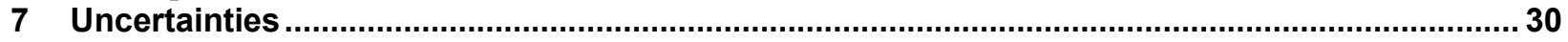

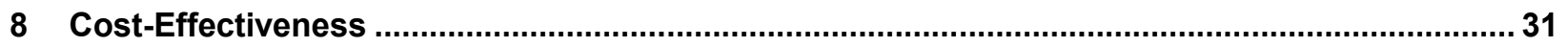

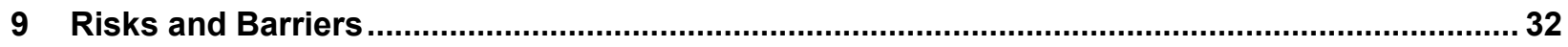

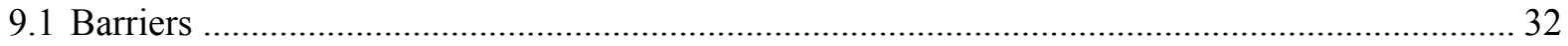

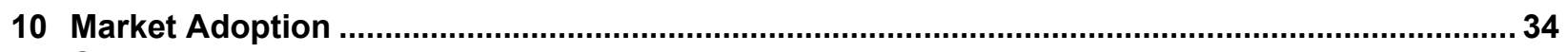

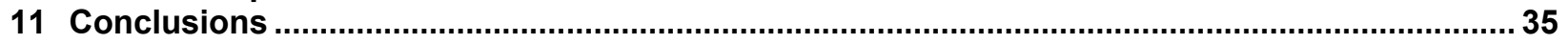

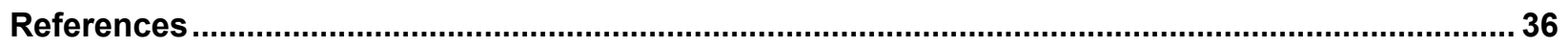

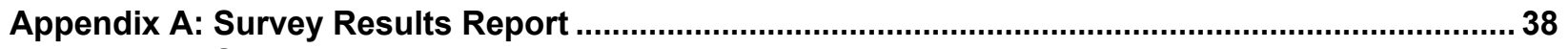

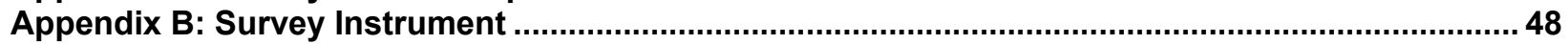

Appendix C: Islip Housing Authority Implementation Guidelines ..............................................52

Appendix D: Raleigh Housing Authority Implementation Guidelines ...........................................62

Appendix E: Philadelphia Housing Authority Implementation Guidelines .................................... 74

Appendix F: Norwalk Housing Authority Implementation Guidelines............................................ 82 


\section{List of Figures}

Figure 1. Typical IHA housing unit.

Figure 2. Potential source energy savings for typical IHA second floor end unit with double glazing

Figure 3. Electric storage water tank with insulation wrap and foamed plumbing penetrations at IHA

Figure 4. Installing gasket on attic hatch and caulking gap around window at IHA..................... 12

Figure 5. Annualized energy-related costs and source energy savings for IHA units ..................... 13

Figure 6. Source energy use comparison for IHA units............................................................... 13

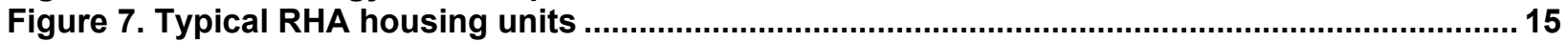

Figure 8. Potential source energy savings for typical RHA two-story end unit (Terrace Park)........ 17

Figure 9. Annualized energy-related costs and source energy savings for RHA unit......................20

Figure 10. Source energy use comparison for RHA units .......................................................... 20

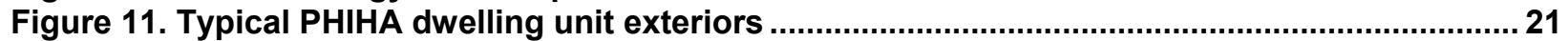

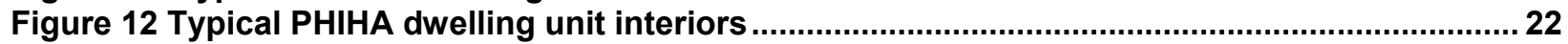

Figure 13. Potential source energy savings for typical PHIHA unit .......................................... 25

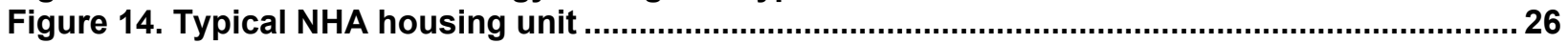

Figure 15. Potential source energy savings for typical NHA second level, two-floor end unit with

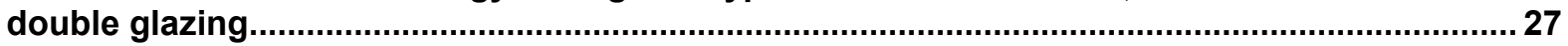

Figure 16. Newly caulked electrical outlet; caulking around base molding at NHA ......................... 29

Figure 17. Sealing ductwork with UL-181 tape; installing weather-stripping on door to

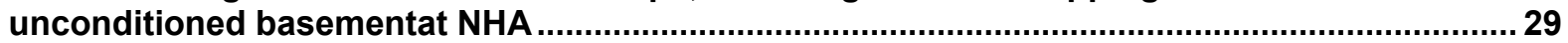

Figure 18. Percentage of PHAs responding by size (as measured by number of units owned) ..... 38

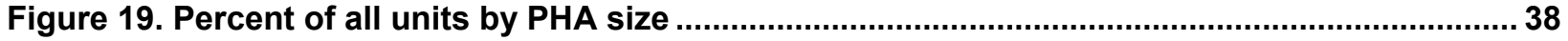

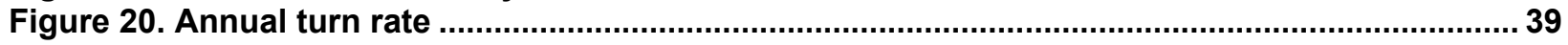

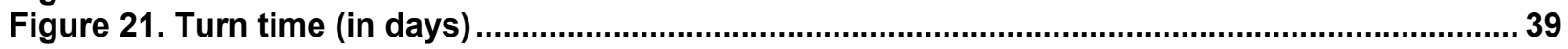

Figure 22. Activities conducted at unit turnover .................................................................... 40

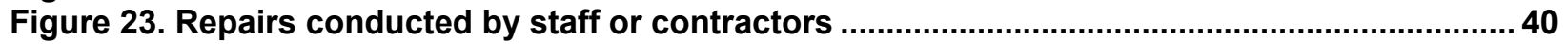

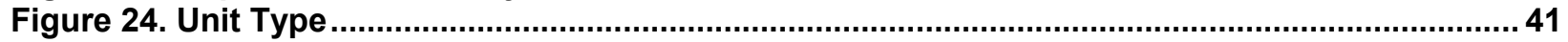

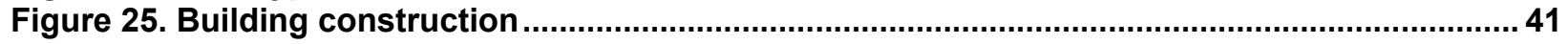

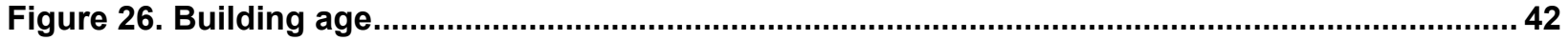

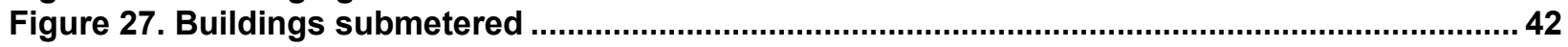

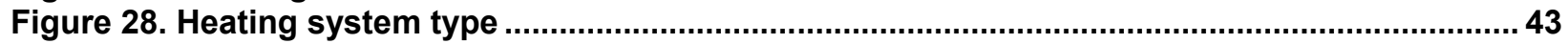

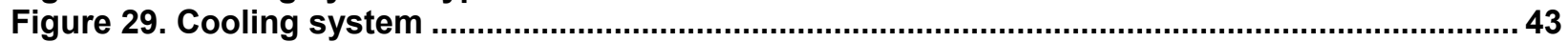

Figure 30. Use of renewables by PHA size, of the 4\% of PHA units using renewables ................... 44

Figure 31. Percentage of units weatherized, by PHA size .......................................................... 44

Figure 32. Interest in water conservation ...................................................................................... 45

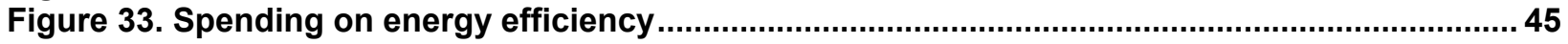

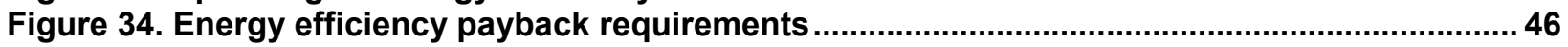

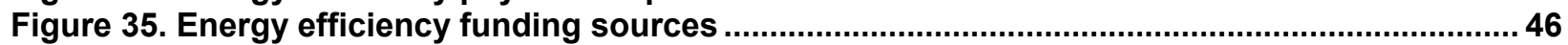

Figure 36. Interest in concept of staff implementation of energy efficiency ..................................... 47

Figure 37. Interest in working with Building America .................................................................... 47

Unless otherwise noted, all figures were created by the Advanced Residential Integrated Energy Solutions Collaborative. 


\section{List of Tables}

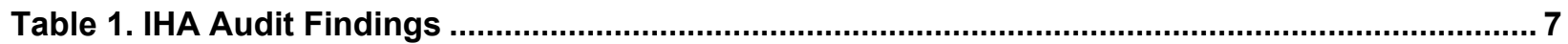

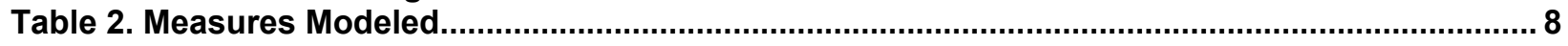

Table 3. Recommended Measures - Estimated Costs..................................................................... 9

Table 4. Recommended Measures-Estimated Costs and Savings not Including Storm Windows 10

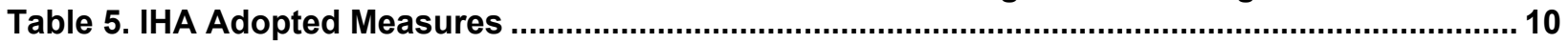

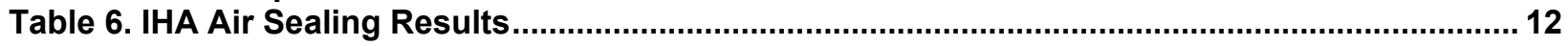

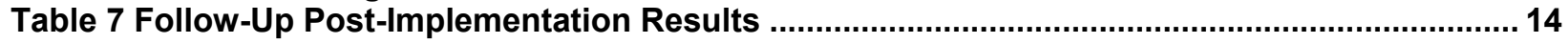

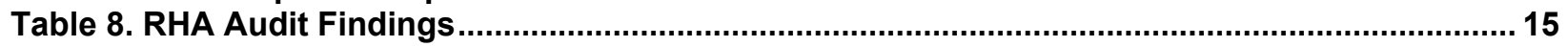

Table 9. Measures Modeled for Potential Savings ….................................................................... 16

Table 10. Estimated Costs for Recommended Measures (Excluding Mechanical Room Door) ....... 17

Table 11. Estimated Costs for the Recommended Measures and Projected Savings...................... 17

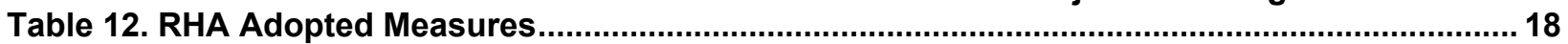

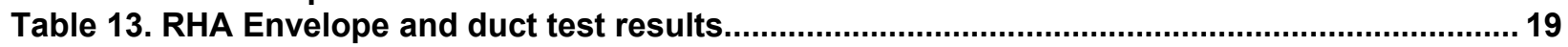

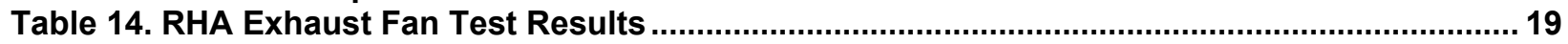

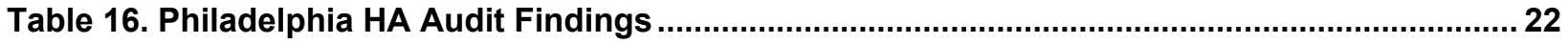

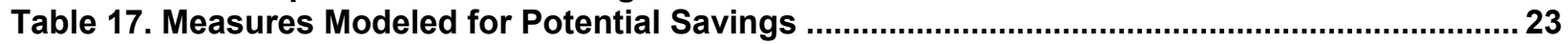

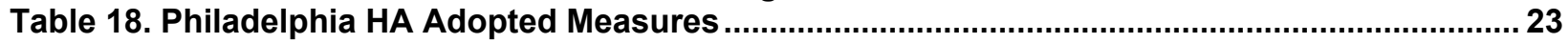

Table 19. Estimated Costs for Recommended Measures ................................................................. 24

Table 20. Philadelphia HA Units Used for Implementation Evaluation ............................................ 24

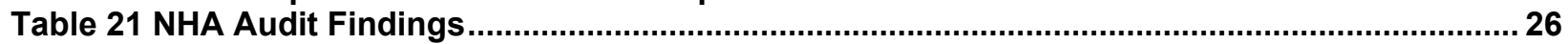

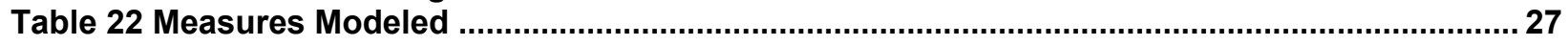

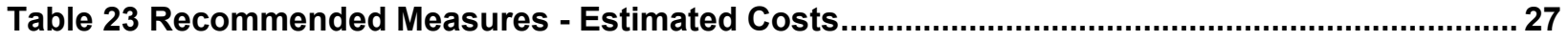

Table 24 Recommended Measures - Estimated Costs and Savings ................................................ 28

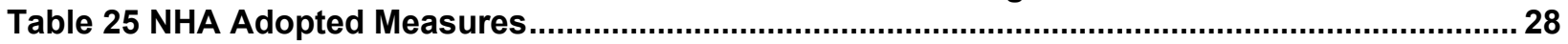

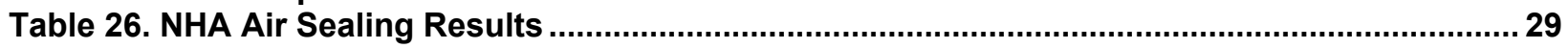

Unless otherwise noted, all tables were created by the Advanced Residential Integrated Energy Solutions Collaborative. 


\section{Definitions}

ACH50 Air Changes per Hour at 50 Pascal pressure differential

AC Air Conditioner, Air Conditioning

ARIES Advanced Residential Integrated Energy Solutions Collaborative

Building America team

BEopt $^{\mathrm{TM}} \quad$ Building Energy Optimization software

CFL Compact Fluorescent Lamp

CFM Cubic Feet per Minute

CFM25 Cubic Feet per Minute at 25 Pascal pressure differential

DHW Domestic Hot Water

EPC Energy Performance Contractor

HUD U.S. Department of Housing and Urban Development

IHA Islip Housing Authority

LED Light-Emitting Diode

NHA Norwalk Housing Authority

PHA Public Housing Authority

PHIHA Philadelphia Housing Authority

RHA Raleigh Housing Authority 


\section{Acknowledgments}

The authors would like to express their appreciation to Gail Keeter, Kat Duke, and Wayne Felton of the Raleigh Housing Authority; Richard Wankle and Katherine Vasilopoulos of the Islip Housing Authority; Barbara Moore and Philip Calhoun of the Philadelphia Housing Authority; and Candace Mayer, Daniel Williamson, and Marcus Bordiere of the Norwalk Housing Authority for their cooperation and willingness to open up their organizations to serve as test beds for this Building America project. The authors are also grateful to Michael Gestwick and Stacey Rothgeb of the National Renewable Energy Laboratory for their guidance and support of this work. 


\section{Executive Summary}

More than 1 million public housing units that are supported by the U.S. Department of Housing and Urban Development provide rental housing for eligible low-income families across the country. These units range from scattered single-family houses to high-rise apartments. In this project, the U.S. Department of Energy's Building America research team Advanced Residential Integrated Energy Solutions Collaborative (ARIES) worked with four public housing authorities (PHAs) to develop packages of energy-efficiency retrofit measures that the PHAs can costeffectively implement with their own staffs during the normal course of housing operations when units are refurbished between occupancies.

ARIES conducted a survey of PHAs before performing this work to assess their receptiveness to this concept and the applicability of the concept to PHA housing units. More than 100 PHAs responded to the survey, and the results support the proposed approach.

The project consisted of a field evaluation in which energy audits were performed on a sample of PHA units at four housing authorities. Energy-efficiency turnover protocols were developed for typical units, the protocols were implemented by PHA staff, and the effectiveness of the protocols was quantified through field testing and modeling.

The energy-efficiency turnover protocols emphasized air infiltration reduction, duct sealing, and measures that improve equipment efficiency. The 18 housing units in which ARIES documented implementation showed reductions in average air leakage of $16 \%$ and duct leakage to the outside of $23 \%$. Total source energy consumption savings were estimated at $3 \%-10 \%$ based on Building Energy Optimization software modeling with a simple payback of 1.6-2.5 years.

Implementation challenges were encountered that mainly related to required operational changes and budgetary constraints. Lack of complete training and inadequate quality control can prevent PHAs from effectively retrofitting units to their full potential. Despite these hurdles, PHA staffs can feasibly incorporate simple improvements such as caulking and sealing penetrations, windows, and doors; sealing duct boots; and adding pipe insulation into a standardized turnover protocol at low or no cost. At typical housing unit turnover rates, these measures could impact hundreds of thousands of units per year nationally. 


\section{Introduction and Background}

\subsection{Introduction}

Public housing was established to provide decent and safe rental housing for eligible low-income families, the elderly, and persons with disabilities. Public housing comes in all sizes and types, from scattered single-family houses to high-rise apartments. Approximately 1.2 million households live in public housing units that are managed by some 3,300 public housing authorities (PHAs) across the United States. The U.S. Department of Housing and Urban Development (HUD) administers federal aid to local PHAs that own and manage the housing. HUD furnishes technical and professional assistance for planning, developing, and managing these developments (HUD 2012a).

In this project, the U.S. Department of Energy's Building America research team Advanced Residential Integrated Energy Solutions Collaborative (ARIES) worked with four PHAs develop packages of energy-efficiency retrofit measures the PHAs could cost-effectively implement with their own staffs during the normal course of housing operations - specifically when units are refurbished between occupancies. These packages are termed the energy efficiency turnover protocols.

\subsection{Background}

PHAs across the nation endeavor to provide good-quality housing for a poor population while working under a number of financial and legal constraints. Living units are small, densely occupied, and primarily attached or in low-rise multifamily buildings.

Challenges to reducing energy use in public housing include the following factors:

- Because of federal rules, residents are generally not responsible for the bulk of their energy costs, which are paid by the agency through a voucher system. Therefore, residents have a reduced financial incentive to conserve energy.

- PHAs in turn have their energy costs reimbursed by HUD based on the previous 3-year average of energy costs; therefore, PHAs have a limited ability to recoup money spent on energy efficiency and little incentive to spend their own money on such measures.

- Although new PHA construction is often built to be energy efficient, many PHA buildings were built before modern energy standards were in place and so are highly inefficient.

- Although PHA management may place a high value on improving energy efficiency, the knowledge, skills, time, and resources to implement cost-effective improvements are often lacking at the operational level.

- PHAs have a strong incentive to minimize downtime between occupancies because of lost rental income. Their desire to avoid disrupting or temporarily displacing occupants inhibits making energy upgrades.

Despite these challenges, PHAs have a number of opportunities to make energy-efficiency improvements: 
- HUD requires PHAs to perform energy audits on their properties every 5 years and offers capital grants that can be used for major energy-efficiency upgrades that are recommended as a result of these audits. In recent years HUD has begun to require PHAs to act on audit findings.

- HUD permits PHAs to contract with energy performance contractors (EPCs) and to share the resulting savings with those contractors. EPCs are significant sources of project funding, particularly for larger PHAs. However, EPCs have minimum project size requirements and typically focus on major replacements and improvements rather than smaller-scale upgrades and maintenance improvements that can still have a significant impact on energy use.

- State and utility energy-efficiency programs frequently offer increased incentives for affordable housing.

- Public housing is eligible for the U.S. Department of Energy's weatherization program.

Even with these programs and funding sources, many units remain inefficient. Capital grants and energy performance contracting is suitable for large one-time projects that affect a limited number of units. Weatherization and utility program funding cannot reach all units. However, PHAs typically have professionals on staff who perform work on units each time occupancy changes (on average every 6 to 7 years according to a survey of PHAs conducted by ARIES; see Section 1.3).

The vacant period between occupancies presents a brief window of opportunity to work on the units. PHAs typically paint and make necessary repairs during this period, but additional energy efficiency work could also be done. Taking the low end of the range of turnover rates yields an opportunity of refurbishing nearly 250,000 units each year across the nation. This opportunity has been noted by others. For example, general recommendations for "Green" measures at "Unit Turnaround" are incorporated into the Green Building Operations and Maintenance Manual (Green Seal and Siemens Industry 2011). However, quantifying the energy savings and costs is still a long way from generalizing that information for typical unit types so PHAs can act on this information with confidence.

This report describes the development, implementation, and evaluation of energy efficiency turnover protocols at four PHAs.

\subsection{Public Housing Authority Survey}

In 2012, preliminary research was conducted on PHAs to assess and quantify the potential role for this approach. An on-line survey was developed to help determine how widely applicable a limited set of standard protocols can be and the degree to which PHAs would be interested. It was vetted by PHA industry members and distributed via industry publications and direct emails to PHA contacts across the country. Information collected included the following:

- The characteristics (type, quantity, etc.) of housing owned by PHAs

- The typical turnover rates

- The typical turnover process with respect to time and tasks completed 
- Methods for paying utility costs

- Willingness to implement energy-efficiency measures during turnover

- The cost-effectiveness criterion used by PHAs in deciding on energy-efficiency investments and related funding sources

- The general skill levels of PHA maintenance staff (i.e., ability to implement energy measures).

The survey was completed by 109 PHAs (3\% of PHAs nationally). The results of the survey support the overall hypothesis of this effort: that a prescriptive set of cost-effective energy measures implemented by PHA staff during turnover is feasible and sensible for some PHAs. Key findings supporting this hypothesis are listed below:

- A large share of PHA units consists of low-rise, wood-frame attached or multifamily units owned by small to midsize PHAs.

- Many PHAs have substantial resident turnover; the turnover times are sufficient in most cases to implement limited energy-efficiency measures.

- ARIES found no evidence that this approach is being used today, yet almost all responding PHAs expressed interest in the concept.

- Many PHAs have some funds to spend on energy-efficiency measures as long as they are cost-effective; most PHAs are interested in efficiency.

- Almost all responding PHAs have professionals on staff with moderate to high skill levels in building maintenance and repairs; these people could presumably be trained to implement simple energy-efficiency measures.

- Most PHA units are more than 30 years old and many have not been weatherized.

The authors recognize that the respondents may be self-selected for their interest in energy efficiency; however, the housing characteristics are presumed to be approximately representative of PHAs nationally. Appendix A summarizes the survey results; Appendix B contains the survey instrument.

\subsection{Relevance to Building America's Goals}

The Building America Standing Technical Committee on Implementation identified the following critical path milestones at the April 2012 Denver meeting (Gestwick 2012):

- 2012: Identify key stakeholders and associated channels that can have the most impact (change) with the least effort. Identify documentation/communication needs of key stakeholders and associated channels. Change key Building America deliverables to cater to the documentation needs of key stakeholders and associated channels.

- 2013: Develop audience-specific communications and outreach strategies with a core focus on measuring results to show changes in practice (define key performance indicators to measure adoption).

PHAs are key stakeholders in that they own and operate 1.2 million housing units nationwide, many of which are in older buildings. PHAs comprise a distinct group with established 
communication and outreach channels. This project developed and tested technical outreach materials (the energy efficiency turnover protocols) that are suitable for many PHAs. In a parallel effort, the Building America Research Alliance has developed and implemented outreach strategies for this approach (BARA 2015).

\subsection{Research Questions}

This research addressed the following questions:

1. Can a prescriptive set of cost-effective energy-efficiency measures be implemented in public housing units during the short turnover periods when the units are vacant?

2. Using partner PHAs as case studies, what specific package(s) of energy-efficiency measures can routinely be installed during these periods that would be cost-effective?

3. What are the estimated costs and energy savings of such a protocol in typical PHA units? 


\section{Research Methods}

The approach to developing the energy efficiency turnover protocols included the following tasks:

1. Select partners. Four PHAs were selected from the survey participants to serve as research partners to help develop and pilot the protocols. These PHAs are located in the mixed-humid and cold climate zones and primarily own attached low-rise housing stock. The four PHAs are:

a. Raleigh Housing Authority (RHA). RHA is one of approximately 130 PHAs in North Carolina (HUD 2012b). RHA owns 1,723 public housing units, mostly in developments ranging from a few dozen to a few hundred units each (RHA 2012). Of RHA's units, 1,109 are one- and two-story, wood-framed attached units in 14 developments; 388 are in two multifamily high rises; and 226 are scattered singlefamily detached homes. Raleigh, North Carolina, is located in Climate Zone 4A.

b. Town of Islip Housing Authority (IHA). The Town of Islip is located on the South Shore of Long Island in Suffolk County, New York (also in Climate Zone 4A). IHA owns and operates four developments with 360 units. All units are in low-rise attached or multifamily buildings, are wood-frame construction, and most have electric resistance heat.

c. Philadelphia Housing Authority (PHIHA). PHIHA owns approximately 14,000 units spread over 33 conventional and 4,300 scattered sites. PHIHA is the fourthlargest PHA in the country (PHIHA 2015). Its sites range from single-family wood-frame townhomes to high-rise multifamily buildings that serve low-income families and senior citizen communities. Philadelphia is also located within Climate Zone 4A.

d. Norwalk Housing Authority (NHA). NHA is located in Norwalk, Connecticut, and is responsible for 1,131 units at 17 developments. NHA's properties include one- and two-story apartment units, as well as townhomes; most properties contain more than 50 living units. NHA's developments are located within Climate Zone 5A.

2. Audits. ARIES conducted detailed energy audits in several units at each PHA representing a cross-section of properties. The purposes were to identify opportunities for low-cost measures and to assess the consistency of the features and conditions of the units across the PHA portfolios. The audits gathered information required for Building Energy Optimization (BEopt ${ }^{\mathrm{TM}}$ ) modeling including duct and envelope leakage testing, ventilation airflow measurements and inspection of insulation and equipment.

3. Modeling. Typical units at each PHA were modeled using BEopt software Version 2.1.0.2 (NREL 2014).

4. Develop protocols. Protocols were developed based on the audit and modeling results and discussions with PHA management. The packages were low-cost, feasible to install during turnover periods, and achievable with staff skills. 
5. Implement and evaluate protocols. PHA staffs were trained in the protocols, which were then implemented in each unit that was being prepared for new tenants. ARIES conducted before-and-after inspections and tests in a sample of units to measure implementation effectiveness and cost. The protocols were refined based on implementation feedback and post-retrofit testing. A supplemental guide to organizing, implementing, and revising the protocols was developed by the Building America Research Alliance (BARA 2015) to aid PHA adoption of the protocols. 


\section{Islip Housing Authority}

\subsection{Energy Audits}

Energy audits were conducted in eight vacant and occupied units in IHA's Oakdale, Mill Pond, Southwind, and Alyn Lane developments, which represent a cross-section of IHA's properties (Figure 1).
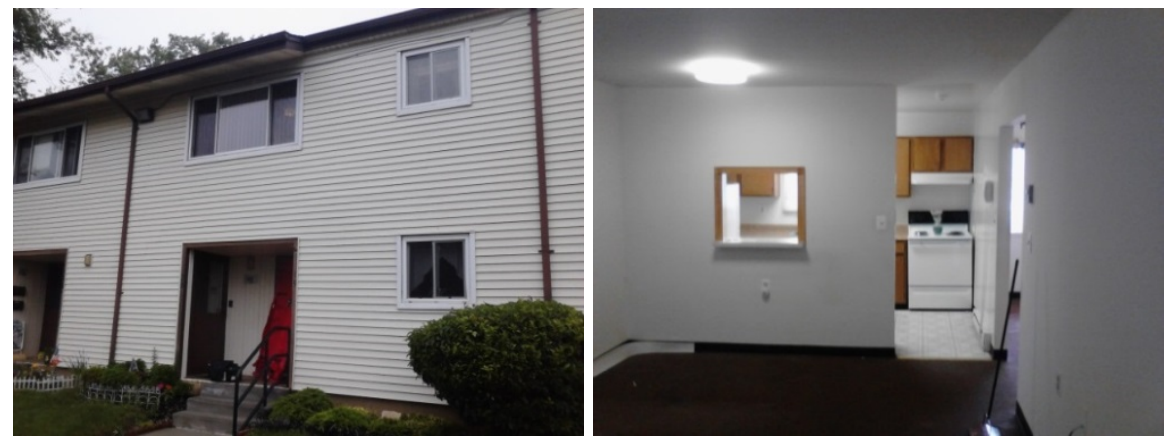

Figure 1. Typical IHA housing unit

IHA's apartments are predominantly single-floor studios and one-bedroom apartments in twostory wood-frame buildings that contain about eight units each. Tenants pay their own utility bills and are given an allowance by IHA based on historical energy use for each unit size. Cooling energy is not reimbursed, and room air conditioners (ACs) (for the 330 electric units) are owned by the tenants. (About half of these residents own ACs). Of the 360 units, 330 have electric resistance heat, electric storage water heaters, and through-the-wall sleeves for residentowned ACs. Table 1 summarizes the audit findings and recommendations. Southwind, a 30-unit site, was an anomaly in that it had gas-fired, forced-air heating, central AC, and a gas-fired water heater. In general, the units displayed significant air leakage; second-floor units were substantially worse than ground-floor units. Some apartments showed signs of earlier attempts at air sealing.

Table 1. IHA Audit Findings

\begin{tabular}{|c|c|}
\hline Inspection Item & Findings \\
\hline $\begin{array}{l}\text { Envelope } \\
\text { Leakage }\end{array}$ & $\begin{array}{c}\text { Blower door test results (unguarded, } \mathrm{ACH} 50 \text { ): ranged from } 6.8 \text { to 22.3, } \\
\text { with an average } 13.9 \mathrm{ACH} 50\end{array}$ \\
\hline Windows & Single and double glazed with metal frame \\
\hline Heating & $\begin{array}{l}\text { Electric resistance baseboard (except for gas-fired forced-air at } \\
\text { Southwind) }\end{array}$ \\
\hline Cooling & $\begin{array}{l}\text { Sleeves for through-wall ACs except for central forced air at } \\
\text { Southwind }\end{array}$ \\
\hline Lighting & $\begin{array}{c}\text { Mostly compact fluorescent lamps (CFLs), pin fluorescents in kitchen, } \\
\text { some incandescents in bathrooms }\end{array}$ \\
\hline $\begin{array}{l}\text { Bath Exhaust } \\
\text { Ventilation }\end{array}$ & Range: 0-60 CFM (only two of eight were higher than $20 \mathrm{CFM}$ ) \\
\hline
\end{tabular}




\begin{tabular}{c|c}
\hline Inspection Item & Findings \\
\hline Hot Water & $\begin{array}{r}\text { Storage tank (electric resistance, except gas at Southwind). Some tanks } \\
\text { had insulation jackets; pipe insulation was inconsistent; some tank } \\
\text { thermostats were set very high }\left(160^{\circ} \mathrm{F}\right) ; \text { water temperature at faucet } \\
\text { measured up to } 150^{\circ} \mathrm{F} .\end{array}$ \\
Ducts & $\begin{array}{r}\text { Only Southwind had ducts; one unit tested at the site: total leakage 350 } \\
\text { CFM25, leakage to outside } 290 \text { CFM25 }\end{array}$ \\
Attic & $\begin{array}{r}\text { Fiberglass batt, mostly evenly dispersed, grades II and III; } 1 / 4 \text {-in. thick } \\
\text { uninsulated plywood attic hatch }\end{array}$ \\
\hline
\end{tabular}

\subsection{Protocol Development}

A typical second-floor IHA unit was modeled using BEopt Version 2.0.0.6 to predict the energy savings of potential measures. The pre-retrofit model was adjusted to match average utility bills obtained for IHA units of the same type. Table 2 summarizes the measures modeled. The BEopt results are provided in Figure 2 for a unit with existing double-glazed windows (most units are double glazed). The model predicts $26 \%$ potential source-energy and site-electricity savings.

Table 2. Measures Modeled

\begin{tabular}{|c|c|}
\hline Area & Measure \\
\hline Attic & Insulate the attic hatch with 2-in. R-10 XPS insulation and gasket \\
\hline Air Sealing & $\begin{array}{l}\text { Air sealing: } 32 \% \text { reduction in leakage from } 11.8 \mathrm{ACH} 50 \text { to outside to } \\
9.5 \mathrm{ACH} 50 \text { to outside } \mathrm{e}^{\mathrm{a}}\end{array}$ \\
\hline Water Heating & Install insulated water heater jacket; pipe insulation \\
\hline Windows & Install storm windows in units with single-glazed windows \\
\hline Heating & $\begin{array}{l}\text { Replace room (through-wall) AC with room (through-wall) heat } \\
\text { pump (seasonal energy efficiency ratio 13, heating seasonal } \\
\text { performance factor 7.7) }\end{array}$ \\
\hline Lighting & Convert to $100 \%$ fluorescent lighting \\
\hline
\end{tabular}

${ }^{a}$ A $15 \%$ reduction factor was used to convert from unguarded envelope leakage test results to envelope leakage used for energy modeling (ARIES Collaborative 2012). 


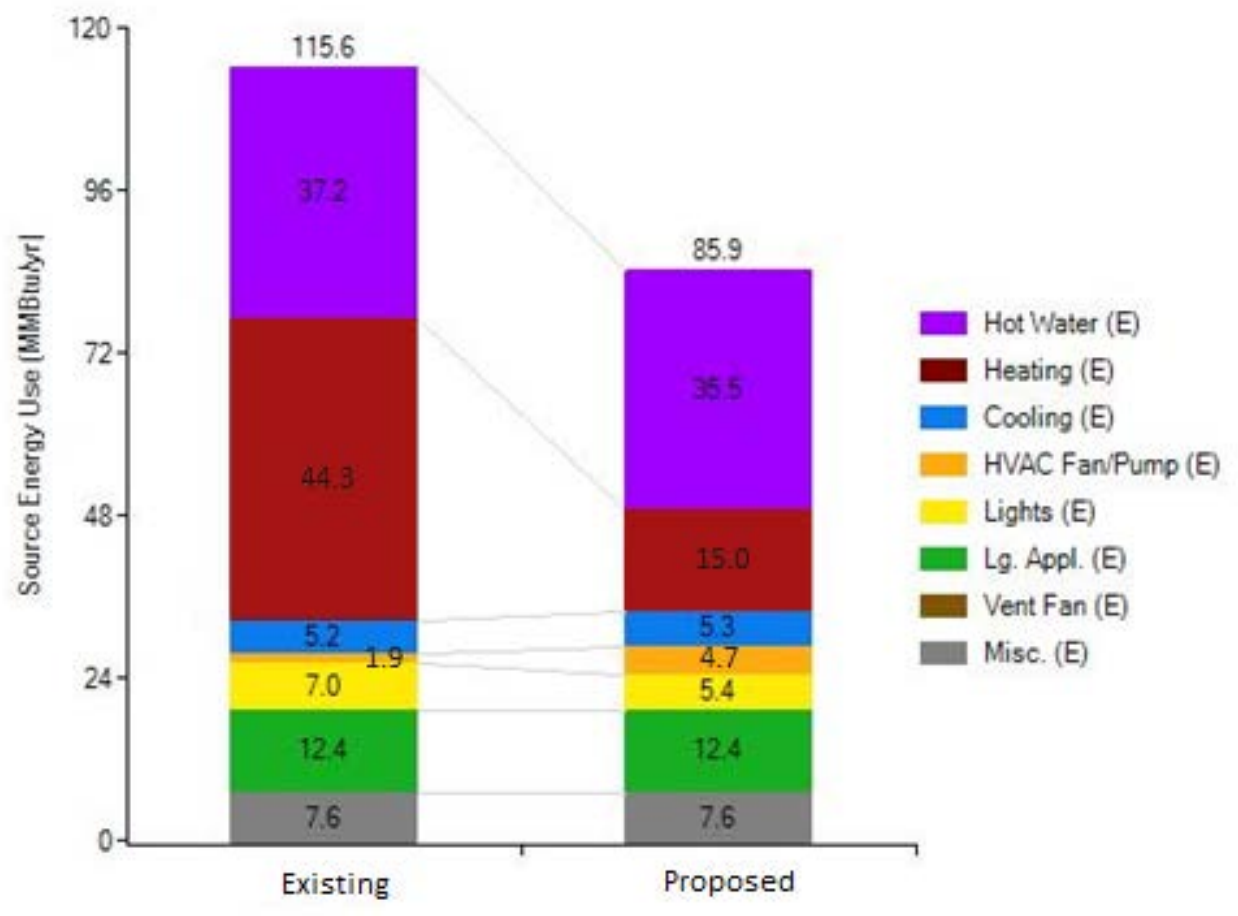

Figure 2. Potential source energy savings for typical IHA second-floor end unit with double glazing ( $\mathrm{G}=$ gas, $\mathrm{E}=$ electric, $\mathrm{Lg}$. Appl. = large appliances)

Changing out space-heating equipment and making modifications to the envelope may contribute to significant reductions in heating energy. Replacing electric resistance heating with a heat pump increases heating, ventilating, and AC fan/pump energy use slightly.

Table 3 and Table 4 list the costs for each measure, total costs, projected annual utility bill savings, and annualized energy-related $\operatorname{costs}^{1}$ for this typical unit.

Table 3. Recommended Measures-Estimated Costs

\begin{tabular}{c|c}
\hline Measure & Estimated Costs Using IHA Staff \\
\hline Attic Hatch & $\$ 5$ for a $1 / 4$ sheet of insulation \\
& $\$ 5$ for a $1 / 4$ roll of rubber gasket \\
Air Sealing & $\$ 2$ for caulk to fasten insulation to attic hatch \\
\hline Programmable Thermostat & $\$ 85$ for caulk and foam \\
\hline Water Heater Jacket & $\$ 25$ for materials \\
Storm Windows & $\$ 650$ installed estimate (homewyse 2014) \\
\hline
\end{tabular}

\footnotetext{
${ }^{1}$ BEopt calculates the annualized energy related costs by annualizing the energy-related cash flows over the analysis period. Cash flows consist of mortgage/loan payments, replacement costs, utility bill payments, mortgage tax deductions (for new construction), and residual values. Costs, excluding mortgage/loan payments, are inflated based on the time they occur in the analysis period. The cash flows are annualized by determining the present worth of the cash flow by converting the total cost for each year to the value at the beginning of the analysis period (NREL 2012).
} 


\begin{tabular}{c|c}
\hline Measure & Estimated Costs Using IHA Staff \\
\hline $\begin{array}{c}\text { Heat Pump } \\
\text { Lighting } \\
\text { Labor }\end{array}$ & $\$ 800$ equipment cost estimate \\
$\$ 48$ fixture cost \\
\hline
\end{tabular}

Table 4. Recommended Measures-Estimated Costs and Savings not Including Storm Windows

\begin{tabular}{c|c}
\hline $\begin{array}{c}\text { Total Capital Costs } \\
\text { (not including storm windows) }\end{array}$ & $\$ 1,120$ \\
\hline Projected Annual Utility Bill Savings & $\$ 442$ \\
\hline Annualized Energy-Related Costs & $\begin{array}{c}\text { Reduced by } \$ 434 \\
\text { from } \$ 1,805 \text { to } \$ 1,371\end{array}$ \\
\hline
\end{tabular}

IHA elected to include in its turnover protocols all recommendations except the programmable thermostat, heat pumps, and storm windows because of their higher initial costs. This reduced the first cost to $\$ 235$. None of the omitted measures are modeled in the implemented case. Heat pumps were initially suggested because they had high potential for savings, and staff could easily install the through-wall units. Replacing electric resistance heating with a heat pump would reduce heating energy spending by IHA and eliminate the need for residents to buy their own AC units. IHA participated in the first round of energy efficiency protocol development for this project, so higher-cost items such as the heat pump were suggested as potential energy-saving options. However, IHA's refusal to implement the higher-cost items indicates that most PHAs would resist measures with high first costs. A detailed summary of recommendations adopted by IHA is provided in Table 5. The implementation cost total for the selected measures was $\$ 235$. The complete IHA energy efficiency turnover guidelines are provided in Appendix C.

Table 5. IHA Adopted Measures

\begin{tabular}{c|c}
\hline Item & Adopted Measure \\
\hline & $\begin{array}{c}\text { Caulk bottom plates in rooms without carpet or if replacing carpet } \\
\text { Foam plumbing penetrations }\end{array}$ \\
$\begin{array}{c}\text { Seal electrical penetrations including boxes to wallboard, openings in data } \\
\text { boxes, and lighting penetrations }\end{array}$ \\
$\begin{array}{c}\text { Envelope } \\
\text { Leakage }\end{array}$ \\
$\begin{array}{c}\text { Foam or tape (with metal foil tape) gaps around exhaust fan and duct boots to } \\
\text { wall/ceiling } \\
\text { Caulk gaps in door frame and/or molding around frame and replace weather } \\
\text { stripping if worn } \\
\text { Tape/gasket all seams between AC and sleeve and inside sleeve in units with no } \\
\text { ACs }\end{array}$ \\
\hline
\end{tabular}




\begin{tabular}{|c|c|}
\hline Item & Adopted Measure \\
\hline Lighting & $\begin{array}{c}\text { Replace incandescent bulbs with standard or warm tone CFLs } \\
\text { Replace pin fluorescent lamps with light-emitting diode (LED) lamps when } \\
\text { replacing fixtures }\end{array}$ \\
\hline $\begin{array}{c}\text { Bath } \\
\text { Exhaust } \\
\text { Ventilation }\end{array}$ & $\begin{array}{l}\text { Check fan flow } 2 \\
\text { Vacuum fan blades, motor, and housing (wipe with rag before air sealing) } \\
\text { If flow still insufficient, check duct connection and consider fan replacement }\end{array}$ \\
\hline Hot Water & $\begin{array}{l}\begin{array}{l}\text { Install insulation jacket or reinstall properly if poorly installed } \\
\text { (electric tanks) }\end{array} \\
\text { Add pipe insulation to uninsulated pipes in domestic hot water (DHW) tank } \\
\text { closet } \\
\text { Set DHW temperature (measured at faucets) to } 120^{\circ} \mathrm{F} \text { maximum }\end{array}$ \\
\hline Ducts & Seal gaps between duct boots and ceiling/floor/wall \\
\hline Attic & $\begin{array}{l}\text { Check that ceiling insulation is evenly dispersed without gaps, water damage, } \\
\text { and covering rafters and other framing members to the exterior walls } \\
\text { When replacing attic insulation over framed walls, foam penetrations where } \\
\text { accessible } \\
\text { Glue 2-in. rigid foam to back of hatch } \\
\text { Add gasket/weather stripping to attic hatch }\end{array}$ \\
\hline
\end{tabular}

\subsection{Implementation}

IHA staff members were trained on the protocols during a 3-hour on-site training session. After the training, they implemented the protocols in each unit that was undergoing turnover (Figure 3 and Figure 4). ARIES conducted before and after inspections and tests of five units, including the training unit, to measure implementation effectiveness and estimate costs.
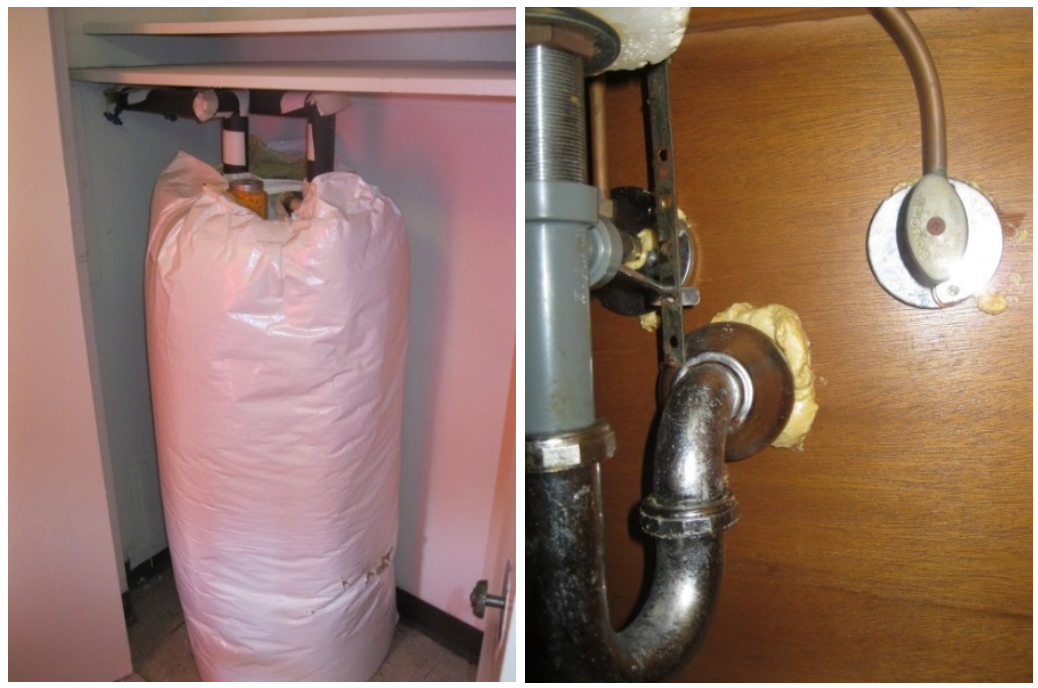

Figure 3. Electric storage water tank with insulation wrap (left); foamed plumbing penetrations (right) at IHA

\footnotetext{
${ }^{2}$ The credit card method was suggested for checking exhaust fan flow; see NYSERDA's "Homeowner's Guide to Ventilation" (NYSERDA 2013).
} 

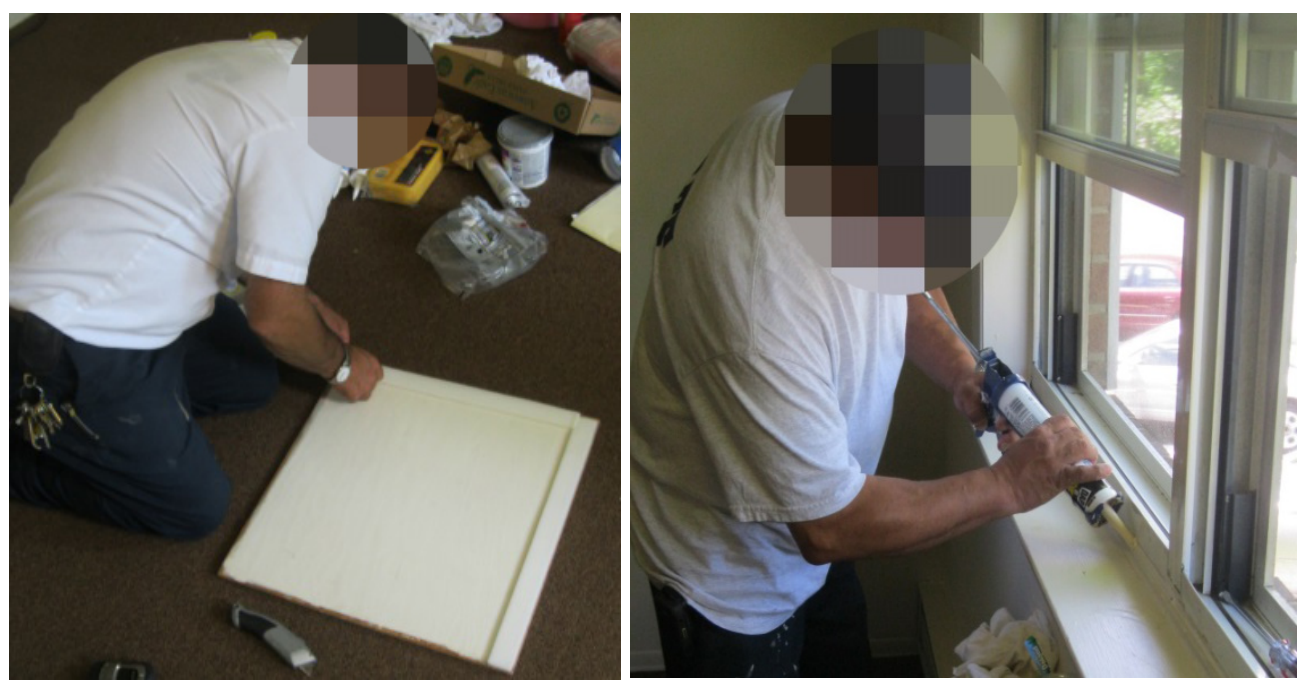

Figure 4. Installing gasket on attic hatch (left); caulking gap around window (right) at IHA

A major focus of the turnover protocols is air sealing. During the training session a $32 \%$ reduction in tested envelope air leakage was achieved. During subsequent implementations the average tested air leakage was reduced by $14 \%-19 \%$ (average of $16 \%$ ). This fall-off in performance is likely due to less on-site focus and supervision by IHA management and ARIES researchers and probably represents an achievable level going forward by IHA staff in these units. Table 6 shows the results of all five units tested at IHA.

Table 6. IHA Air-Sealing Results

\begin{tabular}{c|c|c|c|c|c|c}
\hline & & \multicolumn{2}{|c|}{ Pre-Test } & \multicolumn{2}{c|}{ Post-Test } & \\
\hline Site & Unit & CFM50 & ACH50 & CFM50 & ACH50 & \% Change \\
\hline Oakdale & IO01 & 1,325 & 11.8 & 900 & 8.0 & -32 \\
\hline Central Islip & ICI01 & 1,285 & 15.3 & 1,110 & 13.2 & -14 \\
\hline Bay Shore & IBS01 & 1,624 & 16.7 & 1,309 & 13.5 & -19 \\
\hline Oakdale & IO02 & 1,219 & 17.0 & 1,001 & 14.0 & -18 \\
\hline Oakdale & IO03 & 726 & 10.4 & 621 & 8.9 & -14 \\
\hline
\end{tabular}

Updating the IHA BEopt models with the measures implemented (and with the average measured air leakage reduction of 16\%) yields a predicted whole-house annual energy savings of the IHA units of $6.2 \%$ (7.2 MBtu; $\$ 107$ utility costs). Figure 5 and Figure 6 show BEopt plots that compare potential to predicted savings as implemented. The annualized energy-related costs are based on actual costs incurred by IHA. Substantially greater savings and lower annualized energy costs are possible with the full set of recommended measures; the additional air sealing and heat pumps are the most important measures. 


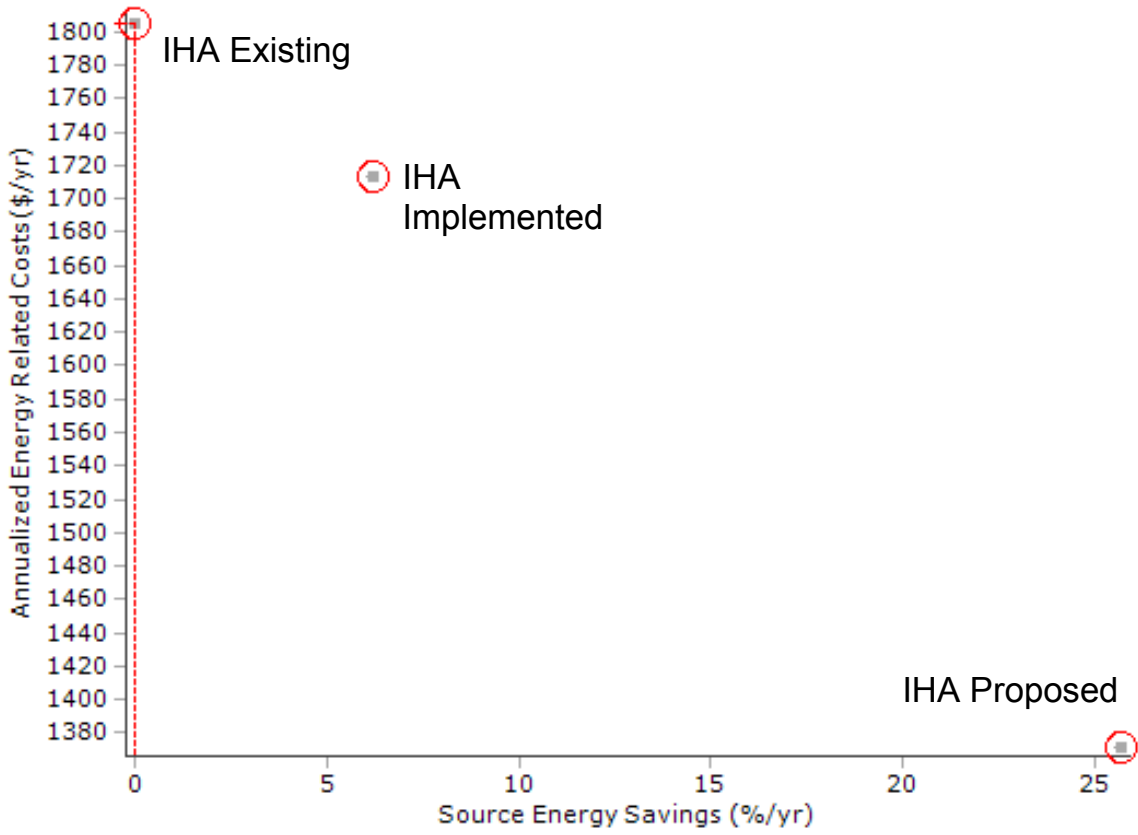

Figure 5. Annualized energy-related costs and source energy savings for IHA units

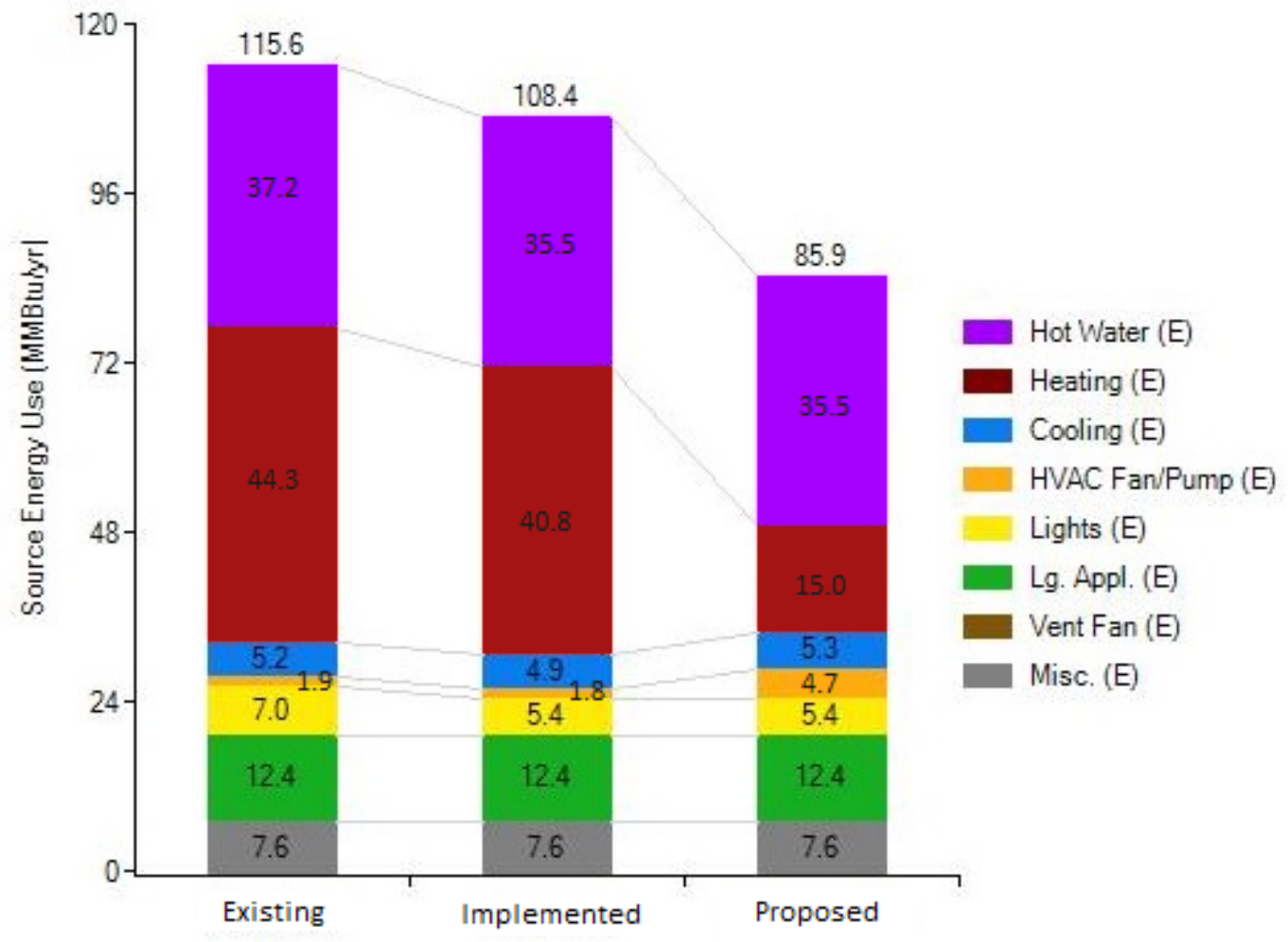

Figure 6. Source energy use comparison for IHA units ( $G=$ gas, $E=$ electric) 


\subsection{Follow-Up}

A post-implementation follow-up visit to IHAs Bay Shore and Central Islip developments was conducted in July 2014 to observe the continuing impact of the energy efficiency turnover protocols at IHA's properties. Air-leakage testing at both units returned encouraging results, outlined in Table 7.

Table 7. Follow-Up Post-Implementation Results

\begin{tabular}{c|c|c|c}
\hline Site & Unit & Post CFM50 & Post ACH50 \\
\hline Bay Shore & IBS02 & 679 & 8.5 \\
Central Islip & ICI02 & 935 & 12.14 \\
\hline
\end{tabular}

Air leakage at both units was on par with the post-implementation results originally observed during the training process. For example, IBS02, a first-floor, single-level unit, achieved a slightly lower ACH50 than did IO03, a similar unit tested during training (see Table 6). Although pre-implementation testing was not conducted on these units, these comparable figures demonstrate that consistent adherence to the energy-efficiency protocols by IHA staff may result in meaningful air leakage reductions.

Other elements of the protocols were either partially adopted or ineffectively executed. For example, though hot water tanks were wrapped in insulation at both units, at Allyn Lane the insulation was insecurely attached to the tank, and the insulation sagged. At Millpond, the insulation blanket was secured with duct tape instead of foil tape, which will dry out over time. Similarly, a bathroom exhaust fan at Millpond, though sealed to the drywall with foil tape per the protocols, was covered in dust, indicating that the fan was not cleaned. The dust likely contributed to a lower exhaust rate.

The positives and negatives uncovered during the follow-up visit were disclosed to IHA in hopes of further improving the turnover process. 


\section{Raleigh Housing Authority}

\subsection{Energy Audits}

Energy audits were conducted in nine vacant and occupied units in RHA's Kentwood, Heritage Park, Mayview, Birchwood, Berkshire Village, Oaks, Stonecrest, Valleybrook, and Terrace Park developments. The apartments are predominantly one- and two-story, one- and two-bedroom units in wood-frame buildings, some of which have brick cladding. All buildings have naturalgas-fired, forced-air heating and central forced-air cooling. Water is heated by a natural-gas-fired storage tank. Tenants pay their own utility bills and are given an allowance by RHA. Typical units are shown in Figure 7. Table 8 summarizes the audit findings and recommendations.
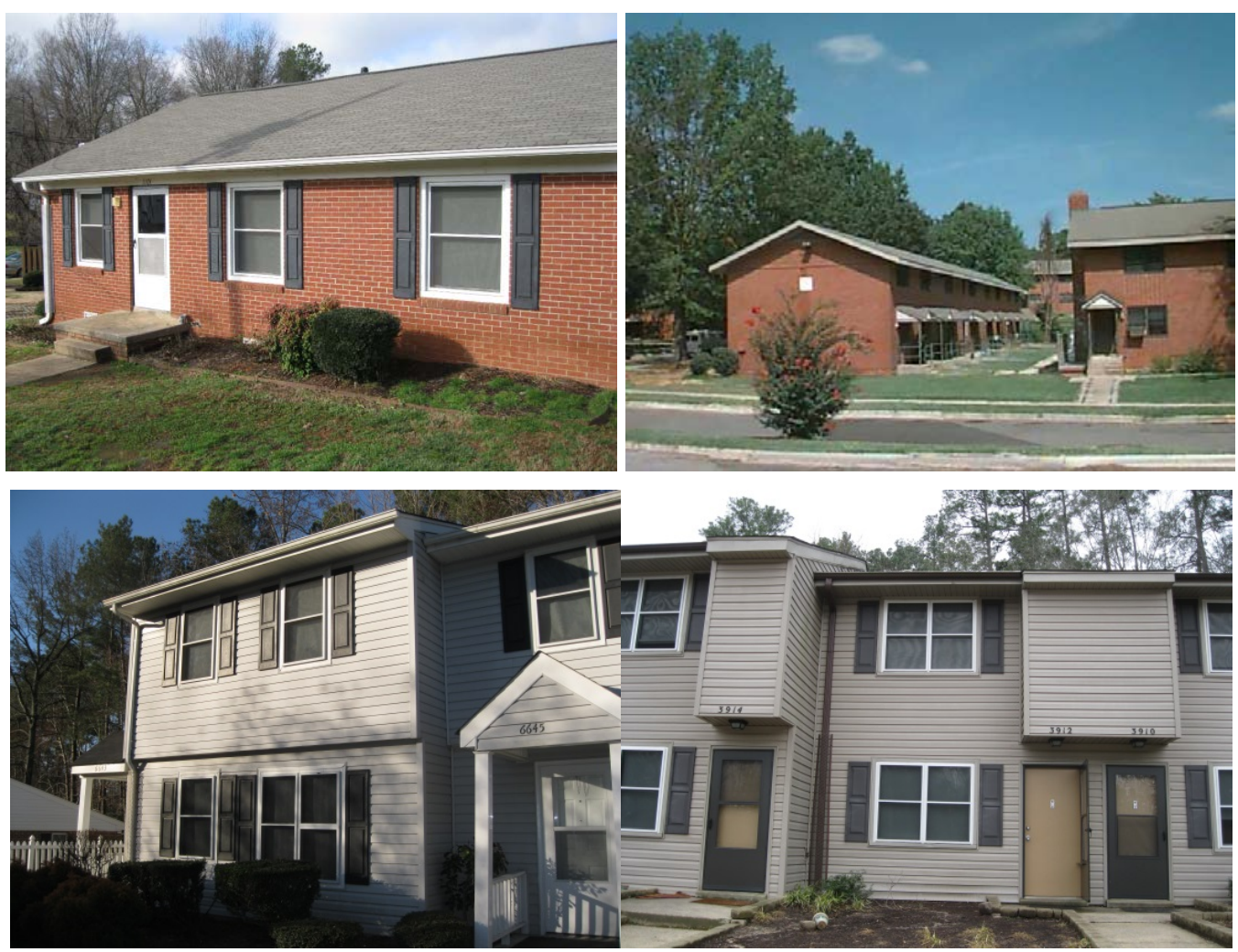

Figure 7. Typical RHA housing units

Table 8. RHA Audit Findings

\begin{tabular}{|c|c|}
\hline Inspection item & Findings \\
\hline Envelope Leakage & $\begin{array}{l}\text { Blower door test results (unguarded, ACH50): ranged from } 17 \text { to } 25 \text {, with } \\
\text { an average of } 20.2\end{array}$ \\
\hline Windows & Single- and double-glazed with metal frame, one vinyl; no storm windows \\
\hline Heating & Forced hot-air, natural-draft furnace located within conditioned space \\
\hline Cooling & Forced-air, traditional split coil direct expansion system; filters dirty \\
\hline Lighting & Mostly incandescent lighting \\
\hline $\begin{array}{l}\text { Bath Exhaust } \\
\text { Ventilation }\end{array}$ & $\begin{array}{l}\text { Low ventilation in bathrooms ( } 0-48 \text { CFM) and kitchens (14-102 CFM), } \\
\text { fan covers very dirty }\end{array}$ \\
\hline
\end{tabular}




\begin{tabular}{c|c}
\hline Inspection item & Findings \\
\hline Hot Water & $\begin{array}{c}\text { Storage tank in louver-door closet; natural gas fuel; natural draft. None } \\
\text { had insulation jackets; thermostats set at about } 120^{\circ}-129^{\circ} \mathrm{F} .\end{array}$ \\
Ducts & $\begin{array}{c}\text { Average duct leakage to outside tested } 29 \mathrm{CFM} 25 / 100 \mathrm{ft}^{2} \text {; average total } \\
\text { duct leakage 31 CFM } 25 / 100 \mathrm{ft}^{2} ; \text { ducts located in vented attic or floor } \\
\text { cavity. Ducts very dirty }\end{array}$ \\
Attic & $\begin{array}{c}\text { Vented attic. Combination fiberglass batts, blown cellulose and blown } \\
\text { fiberglass; inconsistent coverage, grade II to III, depth ranging from } 6 \text { to } \\
14 \text { in. }\end{array}$ \\
\hline
\end{tabular}

\subsection{Protocol Development}

A typical two-story RHA unit was modeled using BEopt Version 2.1.0.2 to predict the energy savings of potential measures. Table 9 summarizes the measures modeled. The BEopt results are provided in Figure 8 for a unit with existing double-glazed windows, which were typical of most units. The model predicts a potential energy savings of $12 \%$. The audits at Raleigh revealed that combustion appliances - the furnace and water heater - were in a closet within conditioned space and separated from the living space by a louvered door. This placement allowed the appliances to draw in some conditioned air. However, combustion and dilution air vents were supplied to the appliances through the vented attic and (where applicable) the crawl space. These spaces essentially connected the closet, and therefore the conditioned space, with unconditioned space. ARIES thus suggested replacing the louvered door with a solid door to reduce the conditioned air lost to the outside and still allow enough air intake through the dedicated makeup air that ran through the attic and crawl space vents. However, this is a special case in which combustion safety was not compromised. Care should always be taken to ensure combustion safety before air sealing by consulting qualified personnel to confirm that units with combustion equipment meet the National Fuel Gas Code standard NFPA-54 (NFPA 2015).

Table 9. Measures Modeled for Potential Savings

\begin{tabular}{|c|c|}
\hline Area & Measure \\
\hline Attic & $\begin{array}{c}\text { Insulate the attic hatch with 2-in., R-10 XPS insulation and gasket, } \\
\text { improve insulation }\end{array}$ \\
\hline Air Sealing & $\begin{array}{c}\text { Air leakage reduction from } 17.2 \text { ACH50 to outside to } 13.1 \text { ACH50 to } \\
\text { outside (24\% decrease) (using the } 15 \% \text { reduction factor applied to the } \\
\text { unguarded test result) }\end{array}$ \\
\hline Ducts & $\begin{array}{c}\text { Seal air handler to stop leaks, seal duct boot to ceiling/floor/wall to reduce } \\
\text { duct-leakage rate to outside by } 33 \% \text { (using average implementation } \\
\text { measures) }\end{array}$ \\
\hline Water Heating & Install insulated water heater jacket and pipe insulation \\
\hline Heating & $\begin{array}{l}\text { Replace louvered door with solid door and gasket to prevent back-drafting } \\
\text { into living space and to reduce infiltration }\end{array}$ \\
\hline Cooling & Replace air filters, clean supply and return grilles \\
\hline Lighting & Convert to $100 \%$ fluorescent lamps or LEDs \\
\hline
\end{tabular}




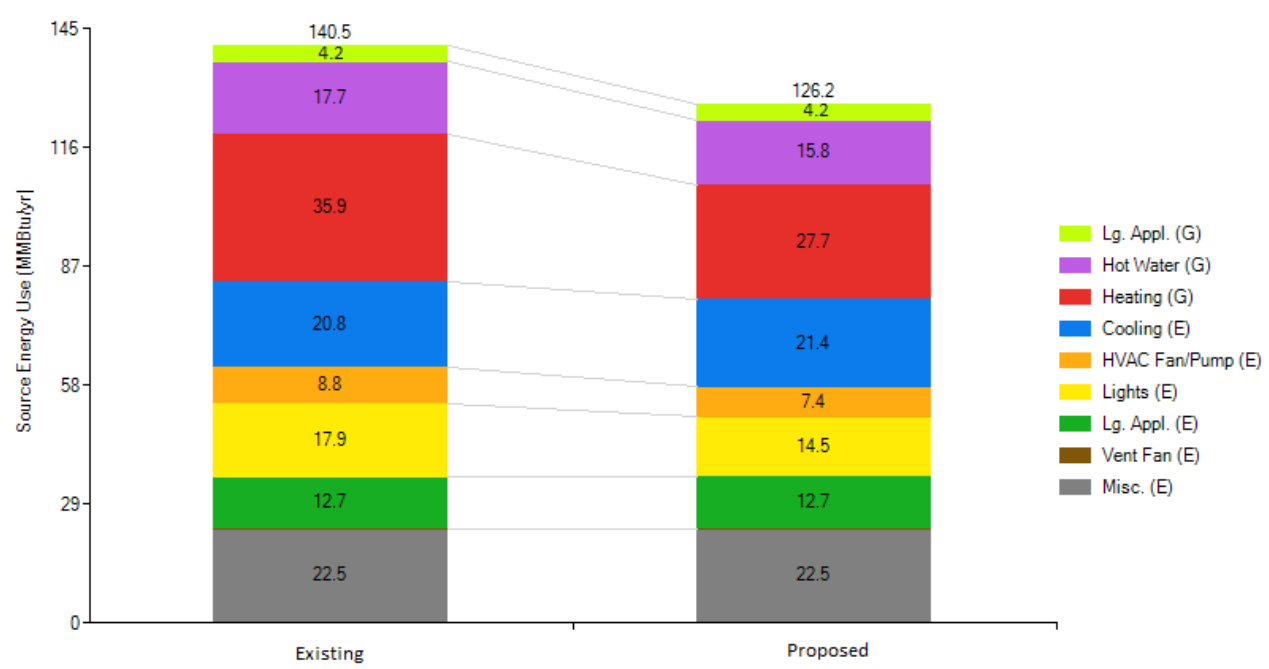

Figure 8. Potential source energy savings for a typical RHA two-story end unit (Terrace Park) ( $\mathrm{G}=$ gas, $\mathrm{E}=$ electric)

Table 10 and Table 11 list the costs for each measure, total costs, projected annual utility bill savings, and annualized energy-related costs for this typical unit.

Table 10. Estimated Costs for Recommended Measures (Excluding Mechanical Room Door)

\begin{tabular}{|c|c|}
\hline Measure & Estimated Costs Using RHA Staff \\
\hline Insulate the Water Heater and Pipes & \$25 for insulating jacket/pipe insulation \\
\hline $\begin{array}{l}\text { Insulate the Attic Hatch with 2-in., } \\
\text { R-10 XPS Insulation And Gasket }\end{array}$ & $\begin{array}{c}\$ 5 \text { for a } 1 / 4 \text { sheet of insulation } \\
\$ 5 \text { for a } 1 / 4 \text { roll of rubber gasket } \\
\$ 2 \text { for adhesive to fasten insulation to attic hatch }\end{array}$ \\
\hline Air Sealing & $\begin{array}{l}\$ 30 \text { for caulk and foam } \\
\$ 1 \text { for acetone for cleaning }\end{array}$ \\
\hline Install Fluorescent Lamps/LEDs & $\$ 45$ for kitchen fixture; $\$ 15$ for CFLs \\
\hline $\begin{array}{c}\text { Seal the Air Handler and Duct } \\
\text { Returns with Foil Tape, and Seal the } \\
\text { Register Boots to the Wall/Ceiling } \\
\text { with Mastic }\end{array}$ & $\begin{array}{l}\text { \$12 for duct mastic (small tub) } \\
\$ 4 \text { for foil tape } \\
\$ 2 \text { for flashing and screws }\end{array}$ \\
\hline Improve Ceiling Insulation & of cellulose insulation-hand distributed \\
\hline Staff Labor & $\$ 116$ for 8.5 hours of labor \\
\hline
\end{tabular}

Table 11. Estimated Costs for the Recommended Measures and Projected Savings

\begin{tabular}{c|c}
\hline Total Capital Costs & $\$ 272$ \\
\hline Projected Annual Utility Bill Savings & $\$ 145$ \\
\hline Annualized Energy-Related Costs & Reduced by $\$ 696$ \\
\hline
\end{tabular}

RHA elected to include in its turnover protocols most recommendations except insulating the water heater and replacing the louvered mechanical room door with a solid door. A detailed 
summary of recommendations adopted by RHA is provided in Table 12 . The estimated cost for the adopted measures was \$247. The complete RHA energy efficiency turnover guidelines are provided in Appendix D.

Table 12. RHA Adopted Measures

\begin{tabular}{|c|c|}
\hline Item & Adopted Measure \\
\hline $\begin{array}{l}\text { Envelope } \\
\text { Leakage }\end{array}$ & $\begin{array}{c}\text { Caulk bottom plates in rooms without carpet or if replacing carpet } \\
\text { Foam plumbing penetrations, including bases of toilets } \\
\text { Seal electrical penetrations including boxes to wallboard, openings in data } \\
\text { boxes and lighting penetrations } \\
\text { Foam or tape (with metal foil tape) gaps around exhaust fan and duct boots } \\
\text { to wall/ceiling } \\
\text { Caulk gaps in door frame and/or molding around frame and replace } \\
\text { weather stripping if worn } \\
\text { Foam door latches }\end{array}$ \\
\hline Lighting & $\begin{array}{c}\text { Inspect lighting and replace with high-efficiency lamps (CFLs or LEDs) if } \\
\text { necessary }\end{array}$ \\
\hline $\begin{array}{l}\text { Bath Exhaust } \\
\text { Ventilation }\end{array}$ & $\begin{array}{c}\text { Check fan flow } \\
\text { Vacuum fan blades, motor, and housing (wipe with rag before air sealing) } \\
\text { If flow still insufficient, check duct connection and consider fan } \\
\text { replacement }\end{array}$ \\
\hline DHW & $\begin{array}{c}\text { Adjust hot water temperature if necessary } \\
\text { Insulate hot water pipes }\end{array}$ \\
\hline Ducts & $\begin{array}{c}\text { Seal gaps between duct boots and ceiling/floor/wall } \\
\text { Seal around air handler/return ducts } \\
\text { Clean or replace filter }\end{array}$ \\
\hline Attic & $\begin{array}{l}\text { Check that ceiling insulation is evenly dispersed without gaps, water } \\
\text { damage, and covering rafters and other framing members to the exterior } \\
\text { walls } \\
\text { When replacing attic insulation over framed walls, foam penetrations } \\
\text { where accessible } \\
\text { Glue 2-in. rigid foam to back of hatch } \\
\text { Add gasket/weather stripping to attic hatch }\end{array}$ \\
\hline
\end{tabular}

\subsection{Implementation}

RHA staff members were trained in the protocols and then implemented the protocols in units that were being prepared for new tenants. ARIES conducted before-and-after inspections and tests of five units to measure implementation effectiveness and estimate costs. Table 13 summarizes the before-and-after envelope and duct-leakage test results. 
Table 13. RHA Envelope and Duct Test Results

\begin{tabular}{c|c|c|c|c|c|c}
\hline \multirow{2}{*}{ Unit } & \multicolumn{3}{|c|}{$\begin{array}{c}\text { Envelope Leakage } \\
\text { (ACH50) }\end{array}$} & \multicolumn{3}{c}{$\begin{array}{c}\text { Duct Leakage to Outside } \\
\text { (CFM25) }\end{array}$} \\
\cline { 2 - 7 } & Before & After & Change & Before & After & Change \\
\hline R01 & 16.5 & 15.5 & $-6 \%$ & 170 & 154 & $-9 \%$ \\
R02 & 18.4 & 15.7 & $-14 \%$ & \multicolumn{3}{|c|}{ Unreliable results } \\
R03 & 13.8 & 12.0 & $-13 \%$ & 280 & 240 & $-14 \%$ \\
R04 & 16.3 & 12.8 & $-22 \%$ & 850 & 437 & $-49 \%$ \\
R05 & 19.1 & 14.5 & $-24 \%$ & 717 & 454 & $-37 \%$ \\
\hline
\end{tabular}

By sealing penetrations, windows and doors, and the overall building envelope, RHA was able to increase airtightness by an average of $20 \%$ after the initial learning curve was surmounted. By sealing duct boots to the walls and floors, RHA was also able to lower the duct leakage to the outside. In some units, such as R05, RHA was able to reduce leakage rates significantly, although compared to new construction standards, envelope and duct leakage are still high. RHA staff did not try to seal the entire duct system, but rather only the easily accessible connections between boots and the ceiling/floor, as well as the air handler. This was consistent with the approach to target measures that could be completed by staff in the allowable timeframe. Of course, the potential for a reduction in duct leakage is greater if more involved sealing is performed, which could increase energy savings.

Bathroom ventilation fan flow was measured in two units and found to be low. After RHA staff cleaned the fans and grilles, the flow increased (Table 14); however, they were still much lower than the 50 CFM target rate.

Table 14. RHA Exhaust Fan Test Results

\begin{tabular}{c|c|c|c}
\hline \multirow{2}{*}{ Unit } & $\begin{array}{c}\text { Pre-Test Result } \\
(\text { CFM) }\end{array}$ & $\begin{array}{c}\text { Post-Test Result } \\
(\text { CFM) }\end{array}$ & $\begin{array}{c}\text { Percent Increase } \\
(\mathbf{\%})\end{array}$ \\
\hline R05 & 0 & 16 & N/A \\
\multirow{2}{*}{ R04 } & Upstairs-19 & Upstairs-32 & 68 \\
& Downstairs-24 & Downstairs-31 & 29 \\
\hline
\end{tabular}

Updating the RHA BEopt models with the measures implemented and average leakage reduction values ( $20 \%$ for envelope ${ }^{3}$ and $33 \%$ for ducts) yields a predicted whole-house annual sourceenergy savings of approximately 8\% (11.4 MBtu; \$117 annual utility costs). Figure 9 and Figure 10 show BEopt plots that compare potential and predicted savings as implemented.

\footnotetext{
${ }^{3}$ Only the last three units were used to derive the average achievable envelope leakage reduction because during the first two the learning curve was not yet overcome.
} 


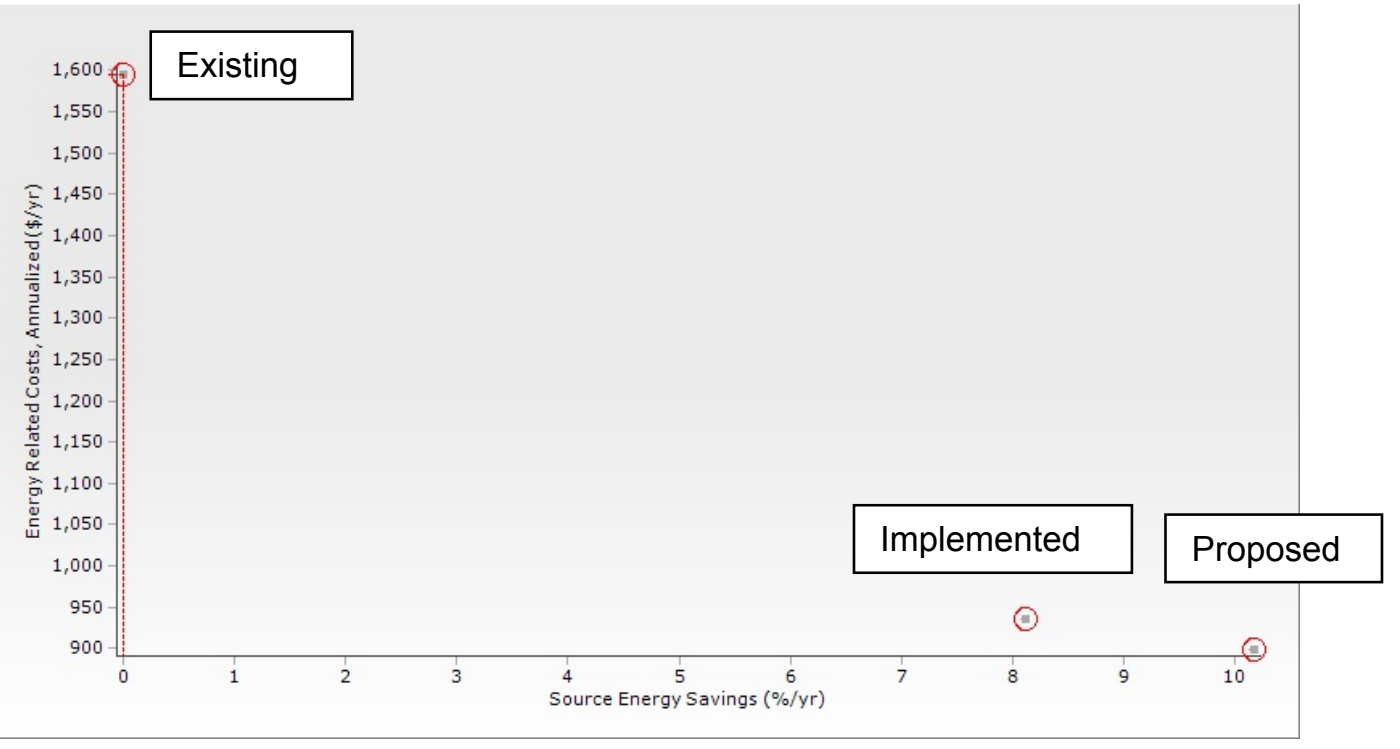

Figure 9. Annualized energy-related costs and source energy savings for RHA unit

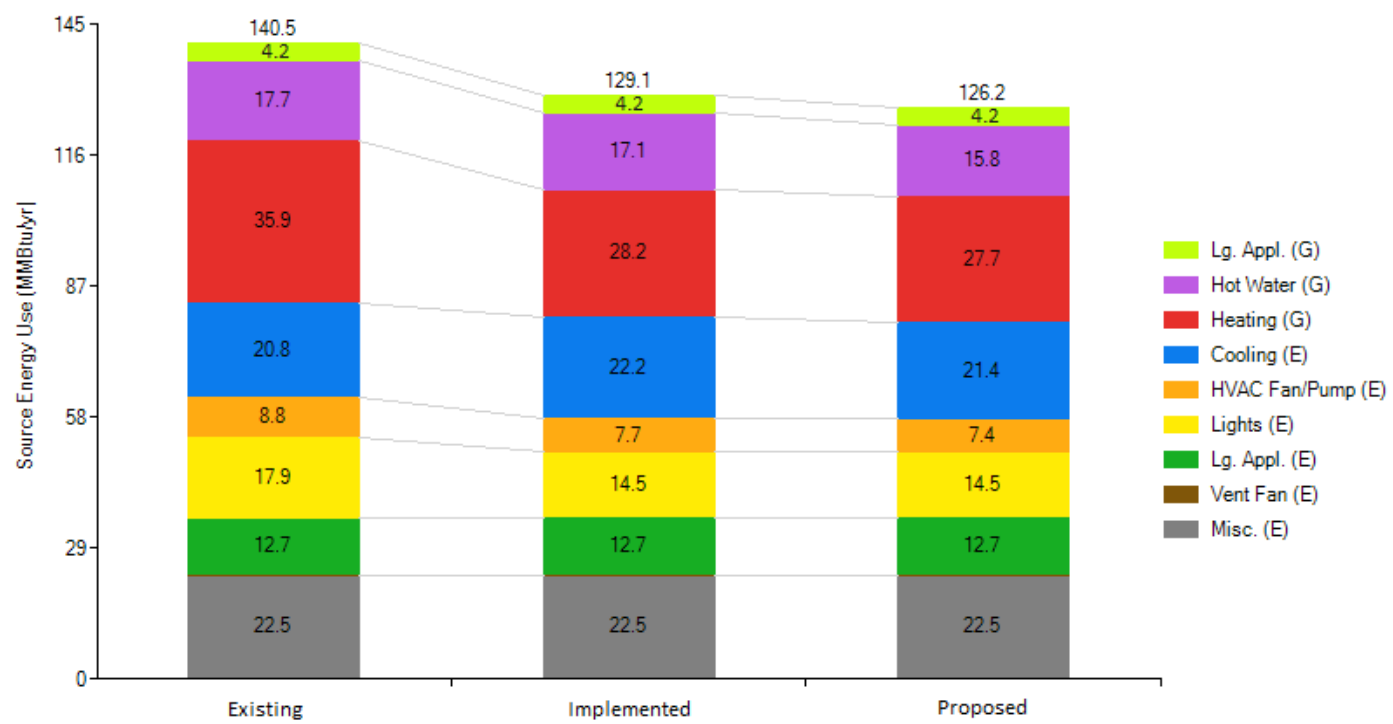

Figure 10. Source energy use comparison for RHA units ( $G$ = gas, $E$ = electric) 


\section{Philadelphia Housing Authority}

\subsection{Audits}

Energy audits were conducted at PHIHA in eight vacant units in its Bartram, Hill Creek, Gray's Ferry, Richard Allen, Morton Homes, and Johnson Homes developments. Inspection results are presented in Table 15. Eight additional units were inspected but not tested.

The apartments are mostly one- and two-level, one- and two-bedroom units in low-rise masonry and framed buildings. The PHA provides space heat and DWH for many units at no charge to the residents. The PHA gives stipends to some tenants in nonconventional, tax-credit sites to help pay their electricity and natural gas bills.

A combination of forced-hot-air and radiant heating systems is used for heating. Residents provide their own window $\mathrm{AC}$ units in the older conventional sites, but some newer sites have central $\mathrm{AC}$. The units overall were in fair to good condition, although some were beginning to deteriorate with age. Typical exteriors and interiors are shown in Figure 11 and Figure 12, respectively. A summary of audit findings is provided in Table 16.

Table 15. PHIHA Inspection Units

\begin{tabular}{c|c|c}
\hline Unit & $\begin{array}{c}\text { Envelope Leakage } \\
\text { (ACH50) }\end{array}$ & $\begin{array}{c}\text { Duct Leakage to Outside } \\
\text { (CFM25) }\end{array}$ \\
\hline PHI01 & 1,300 CFM50 & 490 \\
PHI02 & 14.4 & 25 \\
PHI03 & 4.8 & No ducts \\
PHI04 & 12.3 & 307 \\
PHI05 & 6.9 & 525 \\
PHI06 & 9.1 & No ducts \\
PHI07 & 6.4 & Not tested \\
PHI08 & 9.2 & 470 \\
\hline
\end{tabular}

${ }^{\text {a }}$ ACH50 unavailable
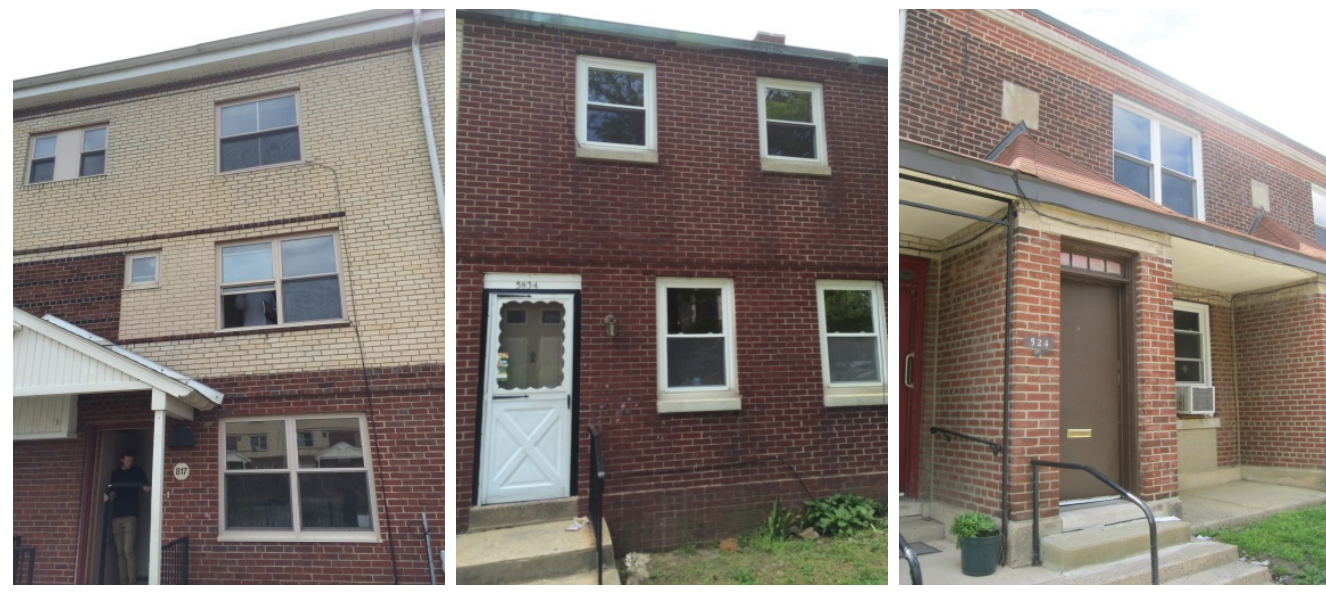

Figure 11. Typical PHIHA dwelling unit exteriors 


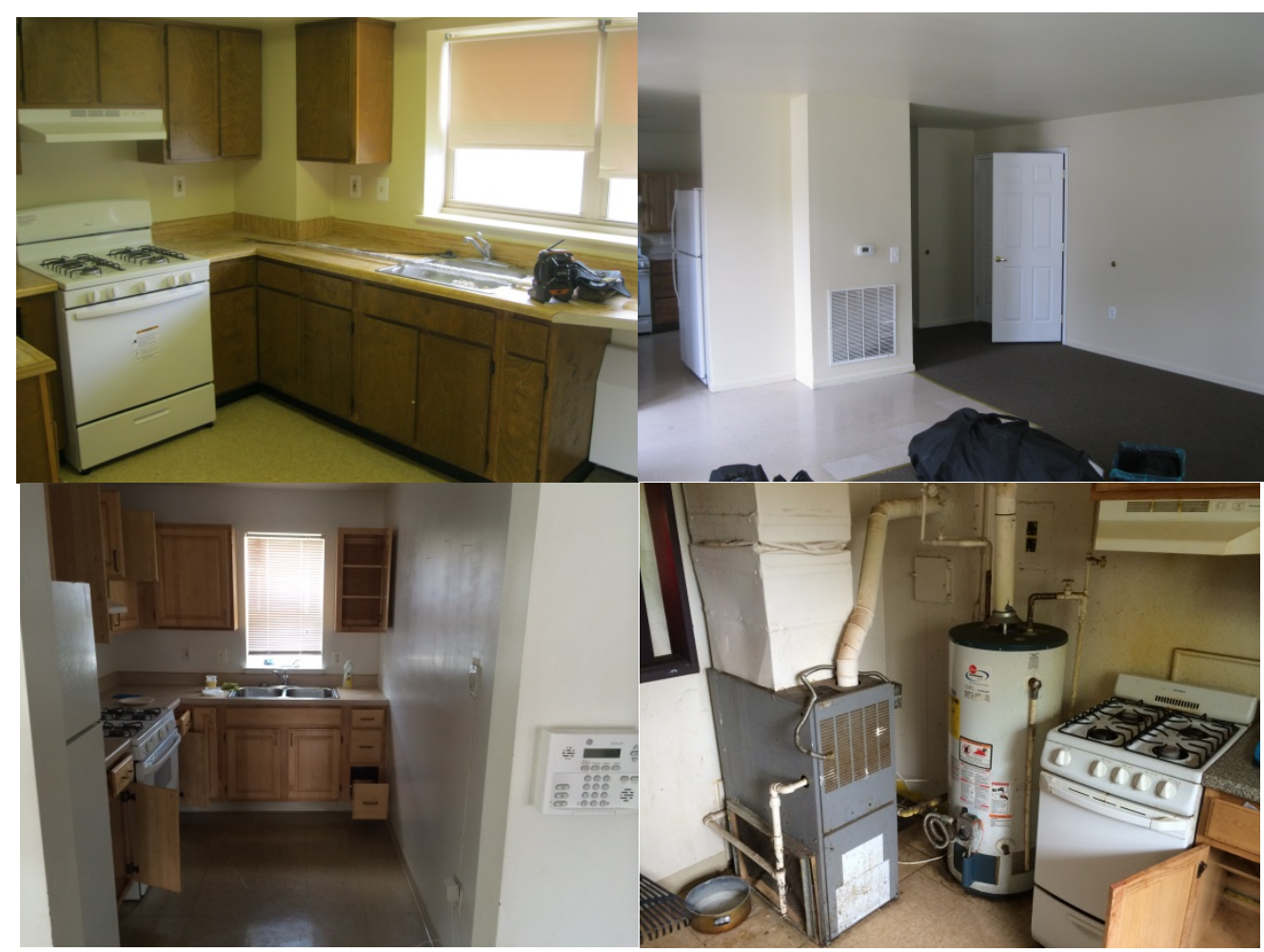

Figure 12. Typical PHIHA dwelling unit interiors

Table 16. PHIHA Audit Findings

\begin{tabular}{|c|c|}
\hline Inspection Item & Findings \\
\hline Envelope Leakage & $\begin{array}{l}\text { Blower door test results (unguarded): ranged from } 9 \text { to } 13 \mathrm{ACH} 50 \text {, with } \\
\text { an average of } 10 \mathrm{ACH} 50\end{array}$ \\
\hline Windows & Single and double glazed with metal or vinyl frames; no storm windows \\
\hline Heating & $\begin{array}{l}\text { Newer units use forced-hot-air, natural draft furnace situated within } \\
\text { conditioned space; older units use central hydronic }\end{array}$ \\
\hline Cooling & Tenant-operated/owned window units; central systems in a few sites \\
\hline Lighting & Mostly fluorescent lighting (CFLs) \\
\hline $\begin{array}{l}\text { Bath Exhaust } \\
\text { Ventilation }\end{array}$ & $\begin{array}{l}\text { Most had no ventilation; those that did generally had low ventilation in } \\
\text { bathrooms }(0-25 \text { CFM })\end{array}$ \\
\hline Hot Water & $\begin{array}{l}\text { Mostly conventional tank (and a few tankless) natural-gas-fueled units. } \\
\text { None had insulation jackets; thermostats set about } 120^{\circ}-129^{\circ} \mathrm{F} \text {. }\end{array}$ \\
\hline Ducts & $\begin{array}{l}\text { Combination of nonducted and ducted units. Average duct leakage to } \\
\text { outside tested at } 17 \mathrm{CFM} 25 / 100 \mathrm{ft}^{2} \text {; average total duct leakage } 30 \\
\text { CFM25/100 } \mathrm{ft}^{2} \text {. Ducts dirty. Register grilles often painted over heavily. }\end{array}$ \\
\hline Attic & $\begin{array}{l}\text { No attics in masonry units. Insulation in fair to good condition at units } \\
\text { with attics; insulation depth ranged from } 6 \text { to } 8 \text { in. }\end{array}$ \\
\hline
\end{tabular}




\subsection{Protocol Development}

A typical one-story PHIHA unit was modeled using BEopt Version 2.1.0.2 to predict energy savings of potential measures. Table 17 summarizes the measures modeled.

Table 17. Measures Modeled for Potential Savings

\begin{tabular}{|c|c|}
\hline Area & Measure \\
\hline Air Sealing & $\begin{array}{l}\text { Air leakage reduction from } 10 \text { ACH50 to outside to } 7.5 \text { ACH50 } \\
\text { to outside (25\% decrease) (using the } 25 \% \text { reduction factor best } \\
\text { implementation result) }\end{array}$ \\
\hline Water Heating & Pipe insulation \\
\hline Ducts & $\begin{array}{l}\text { Duct-leakage reduction from } 24.4 \text { CFM } 25 / 100 \mathrm{ft}^{2} \text { to outside to } \\
20 \text { CFM } 25 / 100 \mathrm{ft}^{2} \text { to outside ( } 18 \% \text { decrease) (using the } 18 \% \\
\text { reduction factor best implementation result) }\end{array}$ \\
\hline Lighting & Convert to $100 \%$ fluorescent lighting \\
\hline
\end{tabular}

Table 18 summarizes the recommendations PHIHA adopted. The complete PHIHA energy efficiency turnover guidelines are provided in Appendix E.

Along with the energy-efficiency measures that were recommended for PHIHA, an equipment assessment checklist was created to help the turnover crews recognize if equipment has to be repaired or replaced. It asks questions that can be answered simply with a "yes" or "no." A "yes" indicates that the equipment needs to be examined by a qualified technician. A "no" indicates that the equipment is operating normally. The checklist is included in Appendix E. Table 18 summarizes the measures adopted by PHIHA.

Table 18. PHIHA-Adopted Measures

\begin{tabular}{|c|c|}
\hline Item & Adopted Measure \\
\hline $\begin{array}{l}\text { Envelope } \\
\text { Leakage }\end{array}$ & $\begin{array}{l}\text { Caulk bottom plates in rooms with new flooring or when replacing cove } \\
\text { molding } \\
\text { Seal plumbing penetrations, including bases of toilets } \\
\text { Seal electrical penetrations including boxes to wallboard, openings in data } \\
\text { boxes, and lighting penetrations } \\
\text { Foam or tape (with metal foil tape) gaps around exhaust fan and duct boots to } \\
\text { wall/ceiling } \\
\text { Caulk gaps in door and window frame and/or molding around frame and } \\
\text { replace weather stripping if worn } \\
\text { Foam door latches }\end{array}$ \\
\hline Lighting & Inspect lighting and replace with high-efficiency lamps (CFLs) if necessary \\
\hline $\begin{array}{l}\text { Bath } \\
\text { Exhaust } \\
\text { Ventilation }\end{array}$ & $\begin{array}{l}\text { Check fan flow } \\
\text { If flow still insufficient, check duct connection and consider fan replacement }\end{array}$ \\
\hline DHW & Adjust hot water temperature if necessary \\
\hline Ducts & $\begin{array}{l}\text { Seal gaps between duct boots and ceiling/floor/wall } \\
\text { Seal around air handler/return ducts } \\
\text { Clean/replace filter }\end{array}$ \\
\hline Attic & $\begin{array}{c}\text { Check that ceiling insulation is evenly dispersed without gaps, water damage, } \\
\text { and covering rafters and other framing members to the exterior walls }\end{array}$ \\
\hline
\end{tabular}


Mechanicals

When/If replacing attic insulation over framed walls, foam penetrations where accessible

Glue 2-in. rigid foam to back of hatch

Add gasket/weather stripping to attic hatch

Inspect mechanical equipment and complete mechanical inspection checklist. Flag issues for follow-up by technicians, as necessary.

Table 19 lists the costs for each measure and the total costs for a typical unit.

Table 19. Estimated Costs for Recommended Measures

\begin{tabular}{c|c}
\hline Measure & Estimated Costs Using PHIHA Staff \\
\hline Air Sealing & $\begin{array}{c}\$ 5 \text { for a } 1 / 4 \text { sheet of insulation } \\
\$ 5 \text { for a } 1 / 4 \text { roll of rubber gasket }\end{array}$ \\
\hline $\begin{array}{c}\text { Install Fluorescents/LEDs } \\
\text { Seal the Air Handler and Duct } \\
\text { Returns with Mastic, and Seal the } \\
\text { Register Boots to the Wall/Ceiling } \\
\text { with Foil Tape }\end{array}$ & $\$ 48$ fixture cost \\
\hline $\begin{array}{c}\text { Improve Ceiling Insulation } \\
\text { Staff Labor }\end{array}$ & $\$ 25$ for mastic and foil tape \\
Total & $\$ 0$ \\
\hline
\end{tabular}

PHIHA elected to not insulate the water heaters in its turnover protocols because of material cost, proximity to cooking range flame in some units, and potential for insulation to become dirty and attract pests. Even though the air handler and duct returns were in conditioned space, they were sealed to enable conditioned air to reach the intended destinations. If conditioned air fails to reach occupied spaces, residents may adjust thermostats and thus increase energy use.

\subsection{Implementation}

PHIHA staff members were trained in the protocols and implementation was observed and tested in five units undergoing the turnover process. Table 20 summarizes the audited units and major test results. Only three units could be fully tested due to on-site challenges including inaccessibility, unsafe conditions, and lack of electrical power.

Table 20. PHIHA Units Used for Implementation Evaluation

\begin{tabular}{c|c|c|c|c|c|c}
\hline \multirow{2}{*}{ Address } & \multicolumn{3}{|c|}{$\begin{array}{c}\text { Envelope Leakage } \\
\text { (ACH50) }\end{array}$} & \multicolumn{3}{c}{ Duct Leakage to Outside } \\
(CFM25)
\end{tabular}


By sealing penetrations, windows and doors, and the overall building envelope, PHIHA crews were able to lower the infiltration rate after they understood which areas needed to be addressed. One of the masonry constructed buildings already had airtight construction (PHI12A, as seen in Table 20). Unlike most PHA units, its infiltration was close to the Building Airflow Standard calculated threshold. Additional ventilation would have been required to provide enough outside air to occupants, according to ASHRAE 62-89, if air sealing had been implemented (BPI n.d.). When enclosures are being air sealed, a qualified professional should be consulted to assess whether mechanical ventilation is necessary. This limit is not often reached in the case of PHAs, but those following these protocols approach should understand this potential issue and take precautions.

Most of the air leakage in this case was concentrated around the plumbing and electrical penetrations and around window frames. Duct-leakage rates were substantially higher than infiltration rates. Cracks on the sheet metal and lack of sealant on the connections between duct flanges and ceiling drywall contributed to high leakage.

Bathroom ventilation fan flow was low. Sealing the fan housing to the ceiling improved rates; however, some fans were in need of replacement.

A typical two-bedroom unit in a masonry building was modeled in BEopt. Implementing the planned measures and predicted leakage reduction values ( $25 \%$ for envelope and $17 \%$ for ducts) yields a predicted whole-house annual source-energy savings of approximately $8 \%$ (8.2 MBtu; $\$ 82$ annual utility costs). Figure 13 shows BEopt results that compare the original and improved unit.

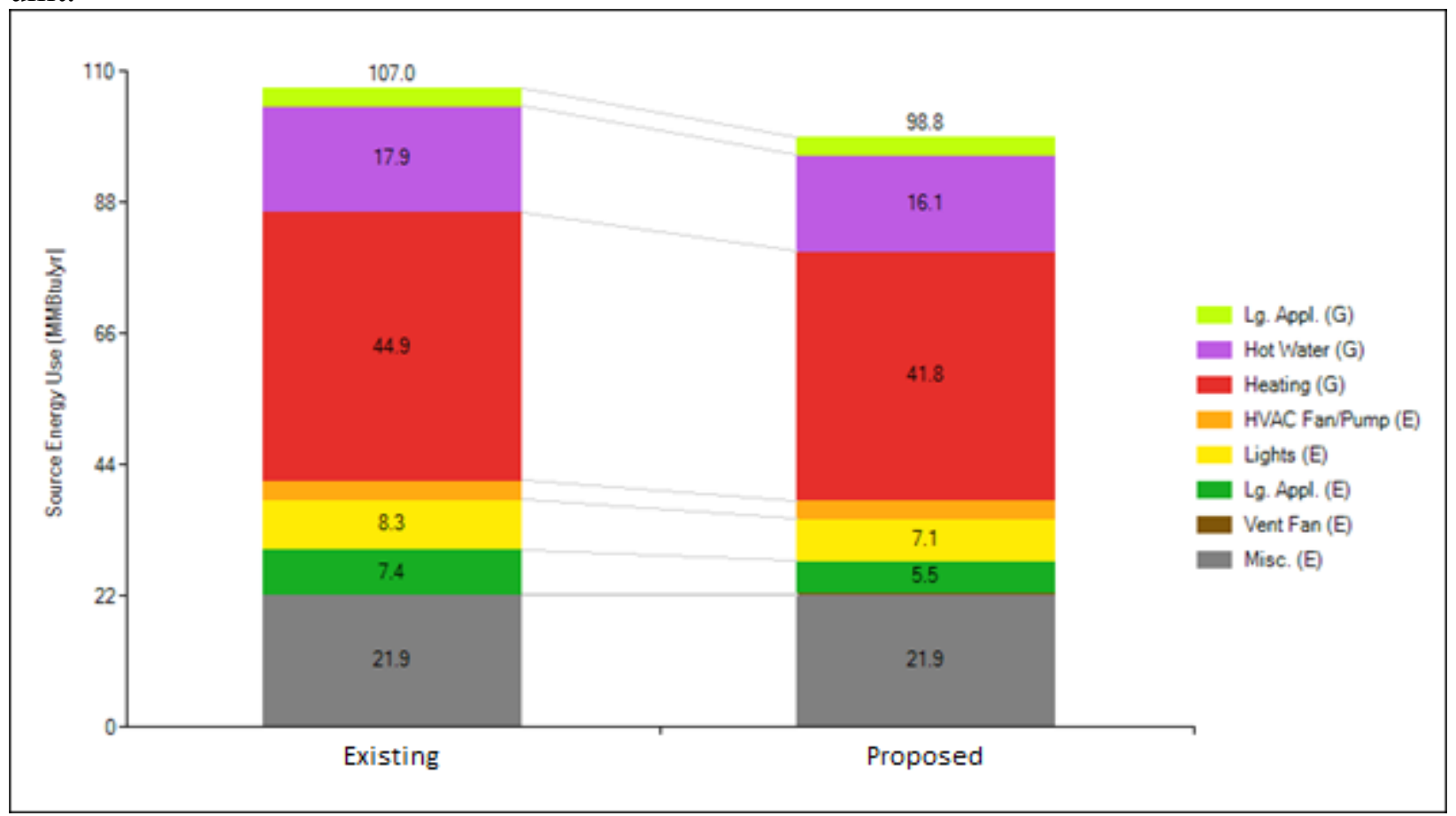

Figure 13. Potential source energy savings for typical PHIHA unit ( $G=$ gas, $E=$ electric) 


\section{Norwalk Housing Authority}

\subsection{Energy Audits}

Energy audits were conducted in nine vacant and occupied units at six NHA properties: Colonial Village, Elmwood, Fairfield Avenue, King Kennedy, Main Street, and Seaview. These developments represent a cross-section of NHA's properties. Figure 14 shows the exterior and interior of a typical NHA unit.
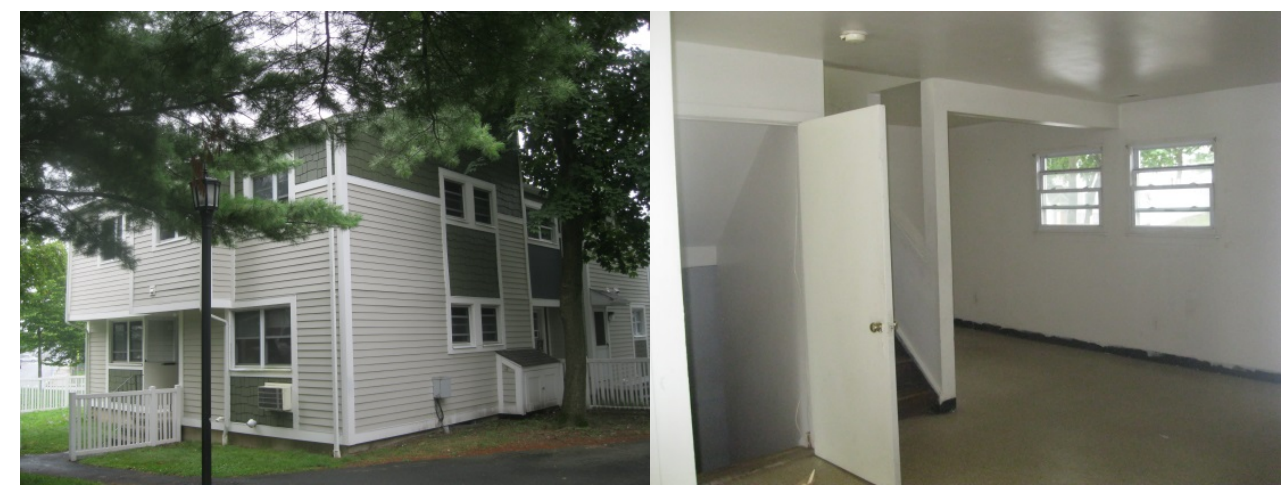

Figure 14. Typical NHA housing unit

NHA manages a range of properties. Although its developments consist primarily of brick or wood-frame low-rise buildings with traditional single-floor apartments, it also has two- and three-floor townhomes and duplexes. Most homes have unitized space and water heating that is achieved through either a combination of hot water boilers with indirect-fired storage tanks or ducted furnaces and stand-alone water heaters. Cooling is chiefly provided by resident-owned window ACs. Table 21summarizes the audit findings.

Table 21. NHA Audit Findings

\begin{tabular}{|c|c|}
\hline Inspection Item & Findings \\
\hline $\begin{array}{l}\text { Envelope } \\
\text { Leakage }\end{array}$ & $\begin{array}{l}\text { Blower door test results (unguarded, ACH50): ranged from } 6.8 \text { to } \\
23.7 \text {, with an average of } 14.6\end{array}$ \\
\hline Windows & Double glazed with vinyl/wood frames \\
\hline Heating & Ducted furnace/instantaneous boiler \\
\hline Cooling & Window ACs \\
\hline Lighting & Mostly CFLs \\
\hline $\begin{array}{l}\text { Bath Exhaust } \\
\text { Ventilation }\end{array}$ & Range: 12-59 CFM (most 15-40) \\
\hline Hot Water & $\begin{array}{c}\text { Storage tank, indirectly fired when paired with instantaneous boiler. } \\
\text { No tank insulation; pipe insulation inconsistent; some tank } \\
\text { thermostats set very high }\left(145^{\circ} \mathrm{F}\right)\end{array}$ \\
\hline Ducts & $\begin{array}{l}\text { Total leakage range: } 270-640 \text { CFM25 (some were } \\
\text { unreadable)Leakage to outside range: } 72-735 \text { CFM25 }\end{array}$ \\
\hline Attic & $\begin{array}{c}\text { Some units had fiberglass batts, mostly evenly dispersed, grade II and } \\
\text { III; others had loose-fill, presumably cellulose; } 1 / 2 \text {-in. thick } \\
\text { uninsulated plywood attic hatches }\end{array}$ \\
\hline
\end{tabular}




\subsection{Protocol Development}

A second-level, two-floor NHA apartment unit at Norwalk's Seaview development was modeled using BEopt Version 2.4.0.0 to predict energy savings of potential measures. The BEopt results are provided in Figure 13. Table 22 summarizes the measures modeled. The model predicts a potential source energy and site electricity savings of $2.7 \%$.

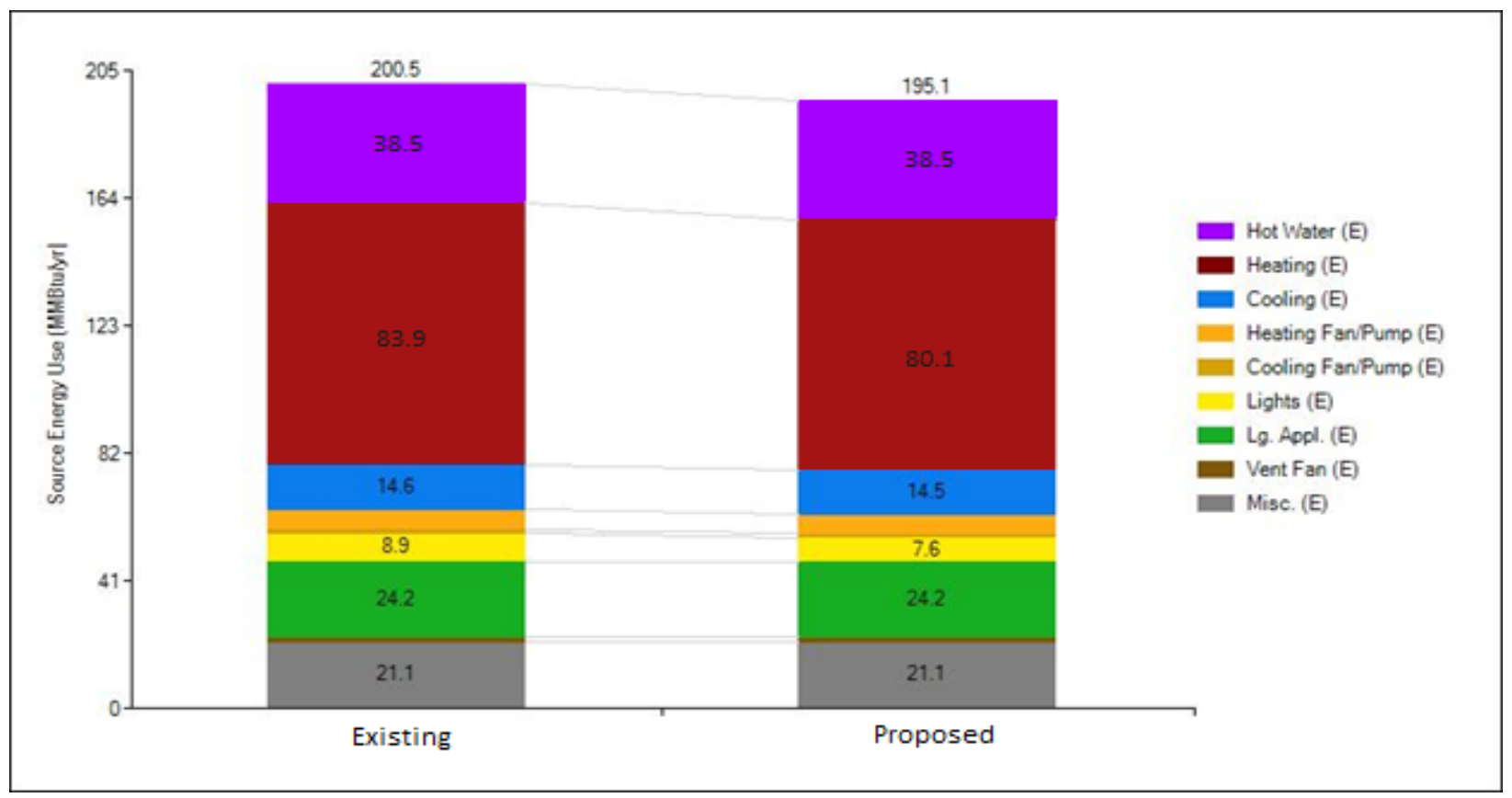

Figure 15. Potential source energy savings for typical NHA second-level, two-floor end unit with double glazing ( $G=$ gas, $E=$ electric)

Table 22. Measures Modeled

\begin{tabular}{c|c}
\hline Area & Measure \\
\hline Attic & Insulate the attic hatch with 2-in., R-10 XPS insulation and gasket \\
Air Sealing & Air sealing: 6\% reduction in leakage from 13 ACH50 to outside to \\
Water Heating & $12.2 \mathrm{ACH} 50$ to outside \\
\hline Lighting & Install insulated water heater jacket \\
\hline
\end{tabular}

Table 23 and Table 24 list the costs for each measure, total costs, projected annual utility bill savings, and annualized energy-related costs for this typical unit.

Table 23. Recommended Measures-Estimated Costs

\begin{tabular}{c|c}
\hline Measure & Estimated Costs Using NHA Staff \\
\hline & $\$ 5$ for a $1 / 4$ sheet of insulation \\
Attic Hatch & $\$ 5$ for a $1 / 4$ roll of rubber gasket \\
& $\$ 2$ for caulk to fasten insulation to attic hatch \\
\hline Air Sealing & $\$ 30$ for caulk and foam \\
\hline Water Heater Jacket & $\$ 25$ for materials \\
Lighting & $\$ 48$ fixture cost \\
Labor & $\$ 100$ for 5 labor-hours \\
\hline
\end{tabular}


Table 24. Recommended Measures-Estimated Costs and Savings

\begin{tabular}{c|c}
\hline Total Capital Costs & $\$ 215$ \\
\hline Projected Annual Utility Bill Savings & $\$ 90$ \\
Annualized Energy-Related Costs & Reduced by $\$ 89$ \\
\hline
\end{tabular}

As stated in Table 23, the modeling results assume a $6 \%$ air leakage reduction. This figure comes from the reduction realized at the sole unit for which post-implementation testing was completed, at NHA's King Kennedy development. Given the higher pre-implementation air leakage results observed at other NHA developments, a $6 \%$ air leakage reduction probably understates the true realizable reduction at most NHA properties.

Presently, only one NHA unit at King Kennedy has fully implemented the turnover protocol. At this unit, NHA elected to focus on recommendations for air/duct sealing and ventilation. The implementation cost for the selected measures was $\$ 215$. The complete NHA energy efficiency turnover guidelines are provided in Appendix C. A detailed summary of recommendations adopted by NHA is provided in Table 25 .

Table 25. NHA Adopted Measures

\begin{tabular}{|c|c|}
\hline Item & Adopted Measure \\
\hline $\begin{array}{l}\text { Envelope } \\
\text { Leakage }\end{array}$ & $\begin{array}{c}\text { Caulk bottom plates in rooms without carpet/vinyl cove or if } \\
\text { replacing carpet/vinyl cove } \\
\text { Foam plumbing penetrations } \\
\text { Seal electrical penetrations at light fixtures and electrical switches } \\
\text { Foam or tape (with metal foil tape) gaps around exhaust fan and } \\
\text { duct boots to wall/ceiling } \\
\text { Caulk gaps in door frame and/or molding around frame and replace } \\
\text { weather stripping if worn }\end{array}$ \\
\hline $\begin{array}{l}\text { Ducts/Air } \\
\text { Handler }\end{array}$ & $\begin{array}{l}\text { Seal between drywall and exhaust fan housing } \\
\text { Seal between drywall and duct boots }\end{array}$ \\
\hline Ventilation & $\begin{array}{l}\text { Vacuum fan blades, motor, and housing } \\
\text { (wipe with rag before air sealing) }\end{array}$ \\
\hline
\end{tabular}

\subsection{Implementation}

NHA staff was trained in the protocols in a 3-hour on-site training session at the King Kennedy unit. Most of the protocols were implemented immediately after the training (Figure 16 and Figure 17); some additional items, such as removing vinyl coves to seal bottom plates, were implemented after the session. ARIES conducted pre- and post-implementation testing to measure implementation effectiveness and estimate costs. 


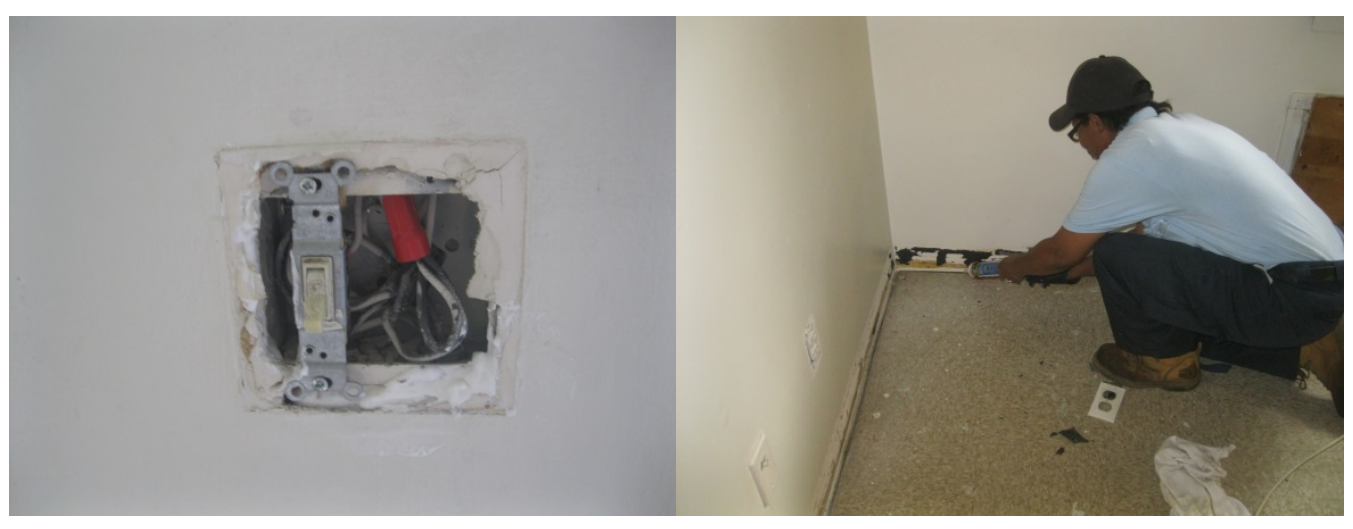

Figure 16. Newly caulked electrical outlet (left); caulking around base molding (right) at NHA

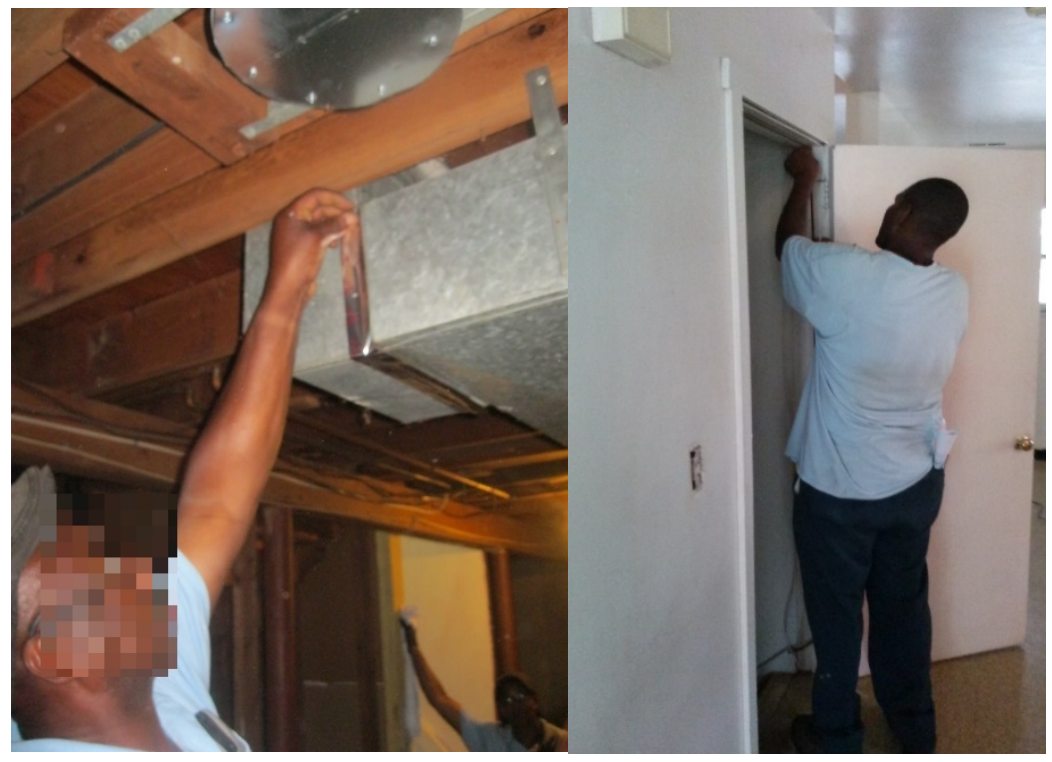

Figure 17. Sealing ductwork with Underwriters Laboratories-181 tape (left); installing weather stripping on door to unconditioned basement (right) at NHA

As with other PHAs, air sealing was a major priority. A 6\% reduction in envelope air leakage was achieved (when testing without the inclusion of an unconditioned basement). Postimplementation testing was performed after the unit was occupied. Three new window ACs were installed during the final testing. Leaks around these units likely contributed to additional air leakage observed during the post-testing that was not present during the pre-testing. Results of testing are presented in Table 26 (leakage figures exclude basements).

Table 26. NHA Air Sealing Results

\begin{tabular}{c|c|c|c|c}
\hline Site & Address & $\begin{array}{c}\text { Pre-Test } \\
\text { ACH50 }\end{array}$ & $\begin{array}{c}\text { Post-Test } \\
\text { ACH50 }\end{array}$ & $\begin{array}{c}\% \\
\text { Change }\end{array}$ \\
\hline King Kennedy & NKK01D & 11.4 & 10.8 & -6 \\
\hline Colonial Village & NCV01 & 15.1 & TBD & TBD \\
\hline
\end{tabular}




\section{Uncertainties}

The Energy Conservatory's blower door with DG-3 or DG-700 manometer was used for envelope leakage measurements with a standard accuracy test (one-point test with baseline range $<5 \mathrm{~Pa}$ ). This test yields an uncertainty of $\pm 10 \%$ (Nelson 2013). The Energy Conservatory's duct blaster with DG-3 manometer was used for duct-leakage measurements. This equipment has a flow accuracy of $\pm 2 \%$ (The Energy Conservatory 2014). Combined with the blower door to measure duct leakage to outside, the total error in the measurements (duct blaster plus blower door) is $< \pm 9.5 \%$.

Exhaust fan flows were measured with The Energy Conservatory's exhaust fan flow meter in combination with a DG-3 manometer, which together yielded an uncertainty of $\pm 10 \%$ (The Energy Conservatory 2012). 


\section{Cost-Effectiveness}

PHAs have a limited ability to fund energy-efficiency improvements out of operating budgets.

Most major improvements are made through one of the programs or funding sources described in Section 1.2. Each improvement has its own cost-effectiveness criteria. The measures included in the turnover protocols are very low cost because of limited operating budgets and because PHAs do not recoup most of the energy savings from reductions in apartment energy use. They are also easy to implement and conscious of time, given the limited resources and time between unit turnovers. That said, as evidenced by the high duct-leakage rates in these residences, slightly more involved measures such as thorough duct sealing have the potential to be cost-effective as long as skilled labor and time are available. 


\section{Risks and Barriers}

The approach of using PHA staff to implement a standard set of energy-efficiency measures at unit turnover poses risks, some of which were encountered during this project. These risks include:

- PHA staff, due to changeover or lack of training, may be underqualified to install the measures or neglect to do so. This could result in missed savings opportunities, or new problems may be created if measures are improperly installed. Attention to proper training along with supervision and quality control procedures can help mitigate this risk. The National Renewable Energy Laboratory has developed the Standard Work Specifications for Home Energy Professionals (NREL 2013). These "Guidelines for Home Energy Professionals," which are available for single-family homes, manufactured homes, and multifamily buildings, can help PHAs establish quality standards, worker certifications, and standard work specifications.

- A PHA may rely solely on the standard protocol for energy-efficiency improvements and ignore other potentially important measures that may be appropriate for individual dwellings or measures such as equipment replacement that require greater funding or special expertise. The periodic HUD-required audits should help mitigate this risk.

- Certain atypical housing units may not fit the standard protocol. Again, the HUDrequired periodic audits should help catch these instances and allow customized measures to be specified for those units.

- Units selected to undergo the implementation process may have other, more important issues to address first, primarily regarding safety. Some of the units encountered during this work were not in the condition to have diagnostic testing performed due to high levels of dust and debris, broken windows, mold, or other damage.

- Air sealing units that do not have active whole-house fresh-air ventilation systems is a potential concern if infiltration is reduced significantly. ASHRAE 62-89, which is used by the BPI Building Analyst Technical Standards (BPI 2012), provides guidance about when infiltration reductions trigger the need to add fresh-air ventilation systems. All wood-frame units involved in this study had at least $20 \%$ higher tested infiltration levels than would lead to recommendations for mechanical ventilation according to this standard. One apartment in a masonry building in Philadelphia, however, was lower than this threshold and therefore should not be air sealed without a provision for ventilation. Tightening units is also a concern if combustion equipment is present, making it absolutely necessary to confirm that NFPA-54 standards are met and that the combustion appliances are still supplied with adequate combustion and dilution air and are vented properly. As mentioned previously, qualified personnel should be consulted in these situations.

\subsection{Barriers}

The introduction of the energy efficiency turnover protocols did encounter some barriers, which are described below. 
- Some PHA staff members had little to no background knowledge about the basics of energy efficiency or building science. Developing relationships with local weatherization assistance agencies to train PHA staff could improve skills and provide a local resource, but funding may prove challenging.

- Training sessions were not fully attended because of scheduling conflicts or emergencies.

- Trained staff did not adequately pass the knowledge on to new staff members or those who missed training sessions. Lack of available staff made it difficult to institutionalize the knowledge and skills needed to properly implement the protocols.

- Quality control was difficult to enforce due to a lack of supervisors and/or inconsistent use of protocol checklists and punch lists that staff should have completed for each unit.

- Materials required by the maintenance or property staff were not always available. This could be due to lack of communication between workers and supervisors or miscommunication about the types of materials needed for a specific unit.

- Use of subcontractors to perform certain work made it difficult to efficiently implement some measures (such as air sealing behind switch and wall receptacle cover plates that were removed and replaced by painting subcontractors). Integration into the subcontractors' scope is one approach, but this may increase subcontract costs.

- Due to the age of some units, components such as duct boots were hard to access because register covers were sealed to the ceiling with multiple layers of paint.

- Despite undergoing training, PHA staff sometimes experienced misunderstandings and misconceptions about the building science principles behind the upgrade protocols. Some staff members thus spent too much time on unimportant items.

- PHA managers sometimes emphasized aesthetics at the expense of energy savings; for example, they prohibited caulk where it may be visible.

- In a few cases, a PHA made incorrect assumptions about building code requirements that might prevent it from implementing recommended measures (e.g., sealing the louvered mechanical room doors or air sealing at electrical receptacles/switches).

- PHA budgetary policies can sometimes prevent even small purchases of inexpensive items such as caulk, weather stripping, and insulation, even when the funds are available. 


\section{Market Adoption}

The energy efficiency turnover protocols are being adopted or promoted by a number of organizations across the United States in addition to those described in this report. A list to date of involved PHAs follows. Some are discussed in more detail in a 2011 report by the Building America Research Alliance (BARA 2011):

- Adoption by the Cleveland Housing Authority, Cleveland, Tennessee. The Cleveland Housing Authority has 434 housing units with an annual turnover rate of $30 \%$. It achieved full implementation in December 2013.

- Adoption by the Franklin Housing Authority in Franklin, Georgia, to implement the checklist in all units being turned over. The Franklin Housing Authority has 77 dwelling units and an annual unit turnover rate of $25 \%$.

- Starting in 2015, incorporation into the procedures of the Massachusetts Department of Housing and Community Development, the agency that oversees and provides technical, administrative, and financial support to PHAs throughout the state.

- Adoption of the package by the Ogle County Housing Authority, Ogle, Illinois, which operates 130 housing units.

- Limited implementation with potential for widespread implementation by New York City Housing Authority, which manages 328 developments.

- Plan for implementation by Jersey City Housing Authority in 150 of its vacant dwellings with third-party implementation.

- Consideration of the package by:

- Maynard Housing Authority, Maynard, Massachusetts

- Shawano County Housing Authority, Shawano, Wisconsin

○ Norwich Housing Authority, Norwich, Connecticut

- Housing Assistance Program of Essex County, Inc., Elizabethtown, New York

- Commitment from HUD to put the energy efficiency unit turnover protocols on its HUD USER website and anticipated coverage in its on-line magazine, the $E D G E$.

- Consideration from the National Association of Housing and Redevelopment Officials to include an article on the energy efficiency turnover protocols in its magazine, Journal of Housing and Community Development, which has more than 10,000 subscribers.

- New Jersey Housing Mortgage and Finance Agency consideration of incorporation into property inspection practices

- Posting of the protocols on the Affordable Housing Design Advisor website, www.designadvisor.org.

- Posting of the finalized peer-reviewed package, once available, on the Affordable Green Academy website, www.affordablegreenacademy.org. 


\section{Conclusions}

A survey of more than 100 PHAs across the country indicated interest in developing low-cost solutions that improve energy efficiency and can be seamlessly integrated into the unit turnover and refurbishment process. Furthermore, PHAs have incentives (both internal and external) to reduce utility bills.

ARIES partnered with four PHAs to test the energy-savings potential of a standard set of efficiency measures that PHA staff could implement during unit turnover. The measures reduced air infiltration, resulted in tighter ducts, and improved overall energy efficiency. ARIES documented the implementation of these measures in a sample of housing units at each PHA. These resulted in average air leakage reductions of $13 \%$ and an average reduction in duct leakage to the outside of $27 \%$ by sealing only easily accessible locations. Total source-energy reduction based on BEopt modeling of adopted measures was 3\%-10\%. A simple payback of 1.6-2.5 years was estimated based on modeling of typical units.

Operational and budgetary difficulties arose during the project. Incomplete training and inadequate quality control can prevent PHAs from effectively retrofitting all units to their full potential. But despite these implementation challenges, combining simple improvements such as sealing and caulking penetrations, windows, and doors, sealing duct boots, and adding pipe insulation can create a turnover package that PHA staff can implement with little budgetary impact. At average housing unit turnover rates, these measures could impact hundreds of thousands of units per year nationally.

The initial research questions, and the answers provided by this work, are provided below:

1. Can a prescriptive set of cost-effective energy-efficiency measures be implemented in public housing units during the short turnover periods when the units are vacant?

Yes. Most of the required work can be completed within a short period of time; the work has a measurable impact on pressurization test results and an effect on energy consumption as estimated via modeling. The effectiveness, quality, and consistency of the result depend to a great extent on the priority placed on it by management and oversight by supervisors.

2. Based on partner PHAs as case studies, what specific package(s) of energy-efficiency measures can routinely be installed during turnovers that would be cost-effective?

Some energy-efficiency measures that can be routinely and easily installed are air sealing, duct boot sealing, cleaning bath fans, installing energy-efficient lighting, and insulating attics. Detailed protocols were developed that describe the measures. These protocols are included in the appendices.

3. What are the estimated costs and energy savings of such a protocol in typical PHA units? Complete labor and material costs were about $\$ 250$ per unit. Annual utility bill savings were about $\$ 100-\$ 150$ per unit, or $6 \%-10 \%$ of the total utility bill. 


\section{References}

ARIES Collaborative. (2012). Case Study of Envelope Sealing in Existing Multiunit Structures. Oak Ridge: U.S. Department of Energy.

BARA. 2011. Outreach Support for the ARIES Collaborative's: "Public Housing: A Tailored Approach to Energy Retrofit” Project: Initial Plan. Oak Ridge: U.S. Department of Energy.

BARA. 2015. Five Steps to Implementing the PHA Energy Efficient Unit Turnover. Oak Ridge: U.S. Department of Energy.

BPI. 2012. Technical Standards for the Building Analyst Professional. Malta, NY: Building Performance Institute.

BPI. n.d. Building Performance Institute Technical Standards for the Building Analyst Professional. Technical Standards.

Gestwick, M. 2012. Building America Critical Path Milestones.

Green Seal, and Siemens Industry. 2011. Green Building Operations and Maintenance Manual. Retrieved November 12,

2012: www.greenseal.org/Portals/0/Documents/IG/PHA\%20Manuals/Green_Building_OM_Ma nual_PHA_Northern.pdf.

Holladay, M. 2015. Simple Methods for Measuring Air Flow. Green Building Advisor. Accessed October 2, 2015: www.greenbuildingadvisor.com/blogs/dept/musings/simple-methodsmeasuring-air-flow.

homewyse. 2014. Cost of Storm Windows. Accessed: January 24, 2014: www.homewyse.com/costs/cost_of_storm_windows.html.

HUD. (2012a). HUD's Public Housing Program. U.S. Department of Housing and Urban Development. Accessed November 12, 2012: http://portal.hud.gov/hudportal/HUD?src=/topics/rental assistance/phprog.

HUD. 2012b. PHA Contact Information. U.S. Department of Housing and Urban Development. Accessed November 12, 2012: www.hud.gov/offices/pih/pha/contacts/states/nc.cfm.

National Renewable Energy Laboratory. (2014, January 8). Home. Retrieved January 8, 2014, from BEopt: http://beopt.nrel.gov/.

Nelson, G. 2013. Blower Door Testing Basics and Beyond. Retrieved February 24, 2014, from RESNET: http://www.resnet.us/blog/wp-content/uploads/2013/03/ResnetCopy_GaryNelson.pdf.

NFPA. 2015. NFPA 54. National Fire Protection Association.

NREL. 2012. BEopt v1.2 Help Menu: Annualized Energy Related Costs. Golden, CO. 
NREL. 2013. Standard Work Specifications Tool. from National Renewable Energy Laboratory. Accessed May 16, 2014: https://sws.nrel.gov/.

NYSERDA. 2013. Homeowner's Guide to Ventilation. New York State Energy Research and Development Authority. Accessed January 24, 2014: www.nyserda.ny.gov//media/Files/EERP/Residential/homeowners-vent-guide.pdf.

PHIHA. 2015. About Us. Accessed December 23, 2015: http://www.pha.phila.gov/.

RHA. 2012. About Us. Raleigh Housing Authority. Accessed November 12, 2010: www.rhaonline.com/about.htm.

The Energy Conservatory. 2012. Exhaust Fan Flow Meter Operation Manual. Retrieved October 8, 2015: http://dev.energyconservatory.com/wp-content/uploads/2014/07/Flow-Box-ManualDG-700.pdf.

The Energy Conservatory. 2014. Duct Blaster ${ }^{\circledR}$ Systems and Accessories. Accessed February 24, 2014: www.energyconservatory.com/products/duct-blaster\%C2\%AE-systems-and-accessories. 


\section{Appendix A: Survey Results Report}

ARIES conducted a survey of PHAs to better understand their housing stock, experience with and interest in energy-efficiency improvements, and to gauge interest in participating in Building America research. The survey was conducted online (see Appendix B for a copy of the survey instrument). Notice of the survey was sent out to PHA contact emails obtained from HUD, published in industry newsletters, and in some states redistributed by local contacts. Responses were received from 109 PHAs, representing 3\% of the 3,300 PHAs in the country. Together, these 109 PHAs manage 48,086 housing units. The major findings of the survey are presented below.

\section{Characteristics of Respondents}

Responses were received from PHAs in 33 states. Although PHAs range in size from single developments with fewer than 20 units owned to PHAs with thousands of units in scores of developments, most PHAs are small (Figure 18), and 61\% own fewer than 3 development sites (Figure 19). Of all respondents, 72\% of the PHAs own fewer than 300 units.

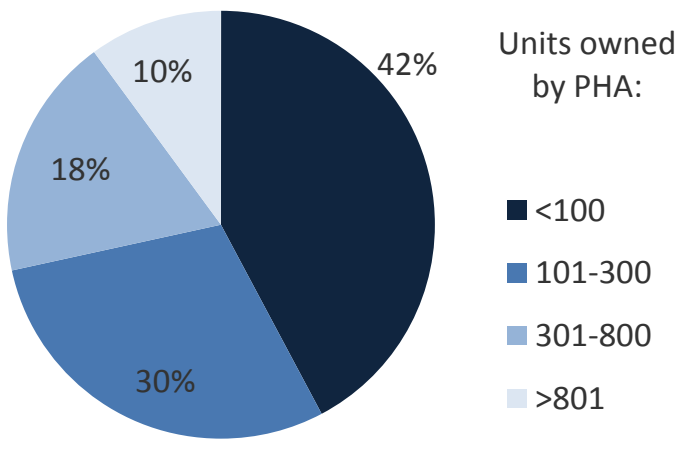

Figure 18. Percentage of PHAs responding by size (as measured by number of units owned)

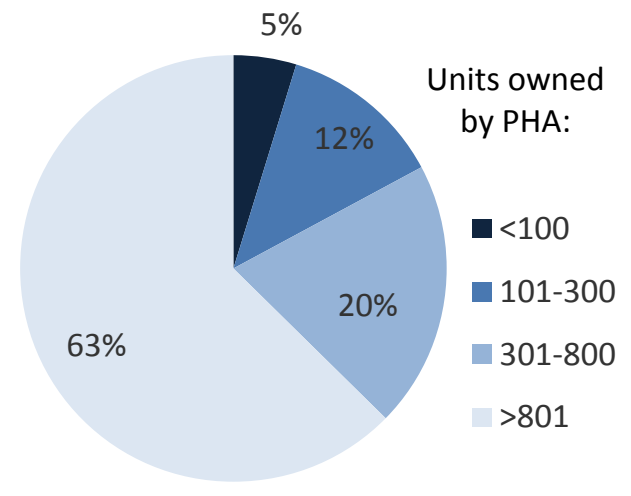

Figure 19. Percentage of all units by PHA size

\section{Turnover}

Because the research hypothesis is that unit turnover presents an opportunity to implement energy-efficiency measures, five questions were asked relating to this subject. The average annual unit turnover rate of the respondents is $16 \%$, but it can be much higher - up to $45 \%$ (Figure 20). The average turnover time is 21 days, but it can be as short as 3-4 days in highdemand areas or much longer in lower-demand areas (Figure 21). 


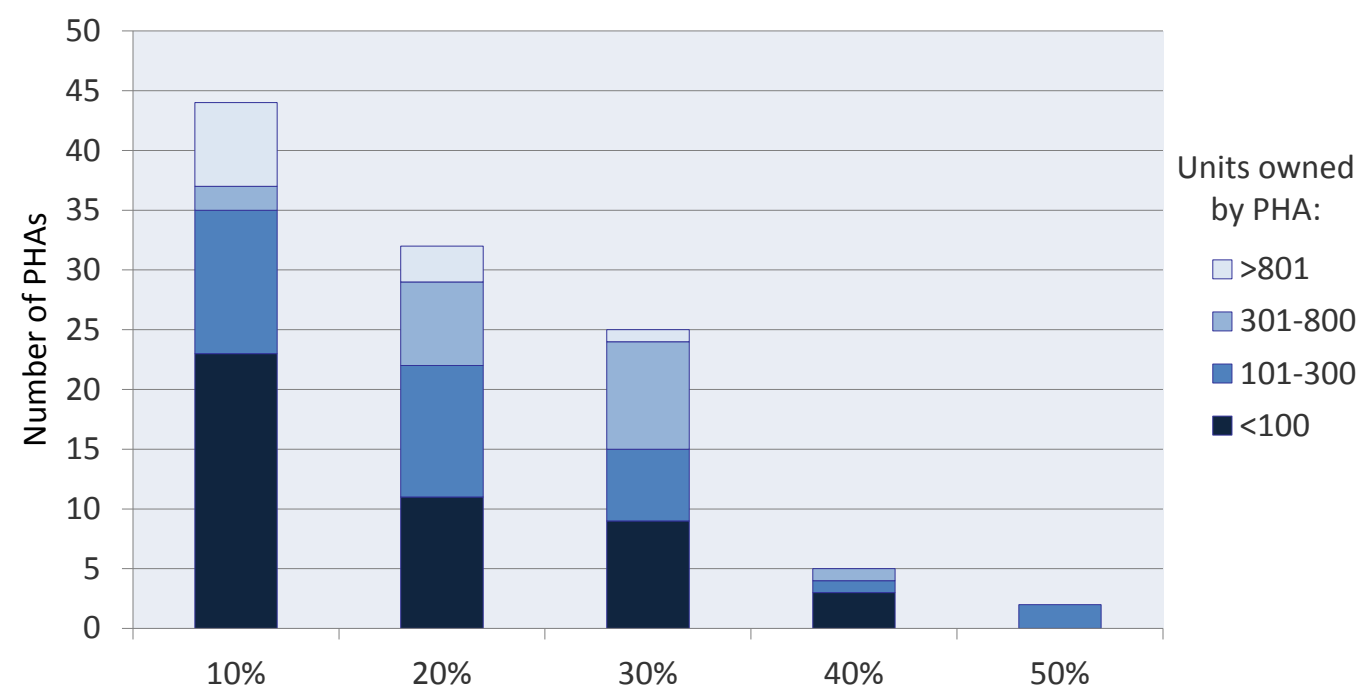

Figure 20. Annual turnover rate

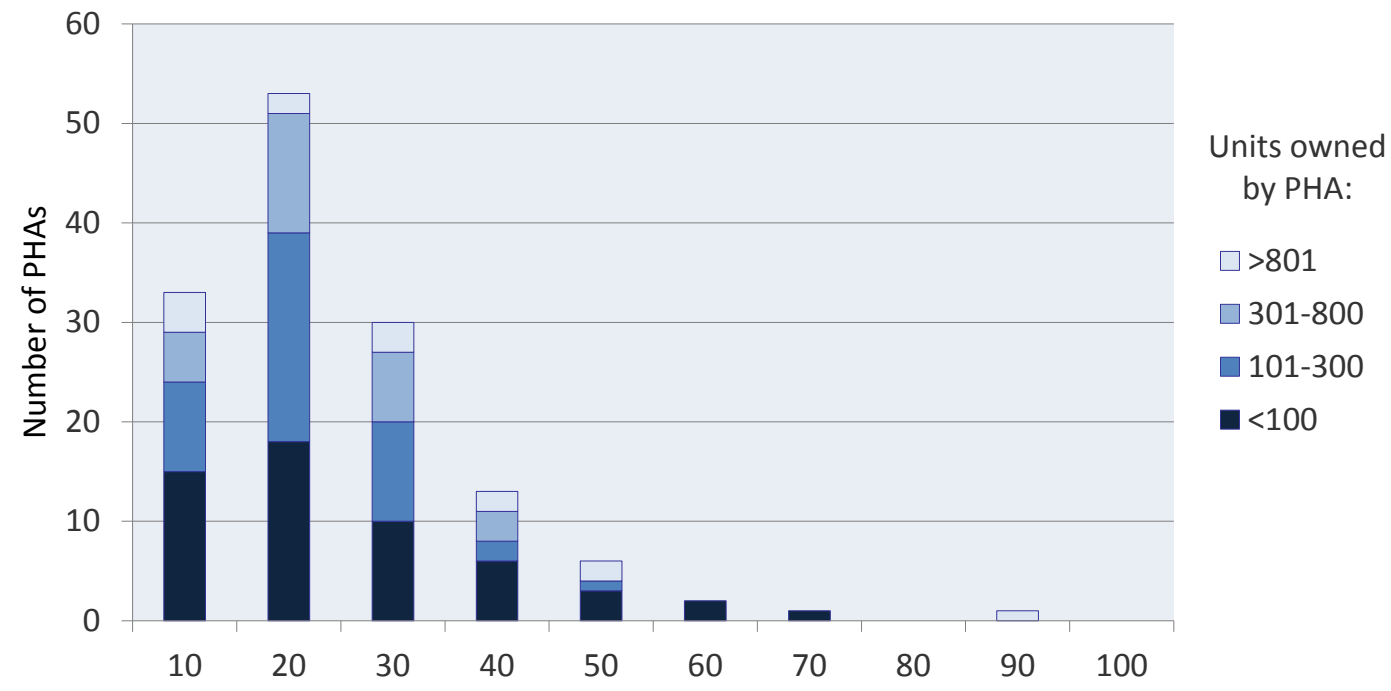

Figure 21. Turnover time (in days)

Almost all PHAs paint, clean, and make minor repairs during turnover, but very few perform major work at this time (Figure 22). The vast majority of PHAs have in-house staff members who perform this work (Figure 23). 


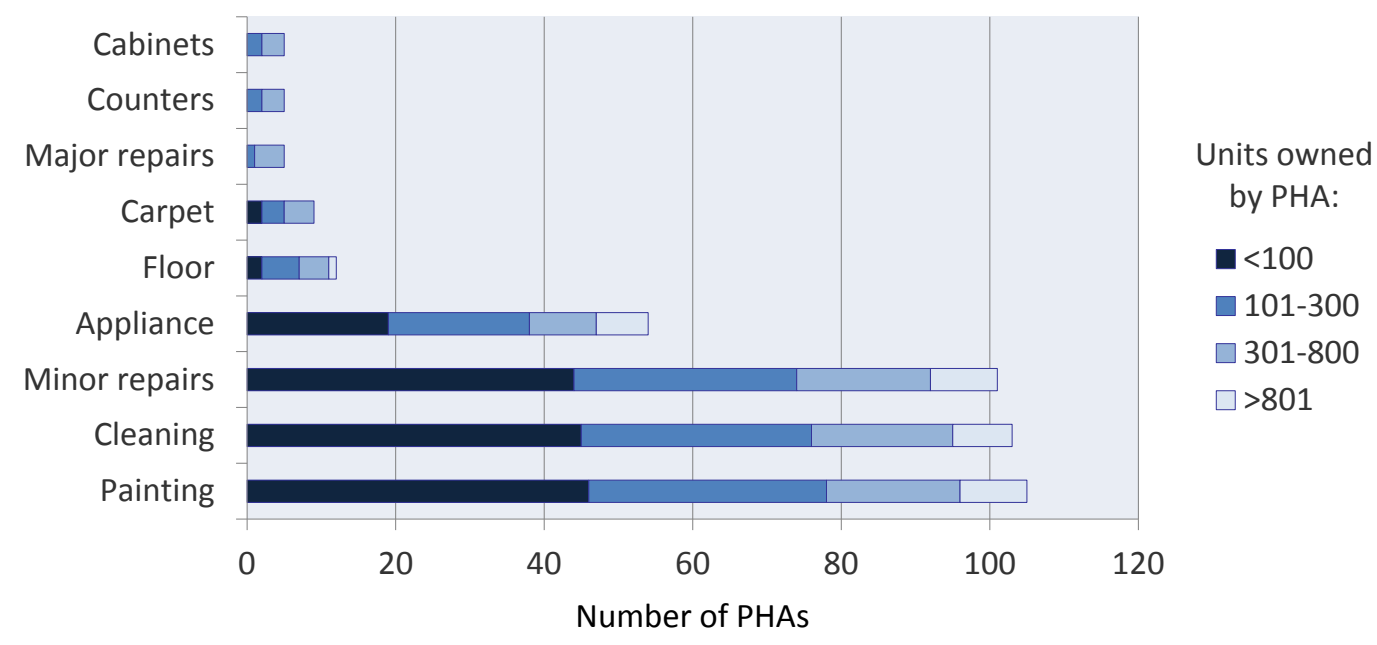

Figure 22. Activities conducted at unit turnover

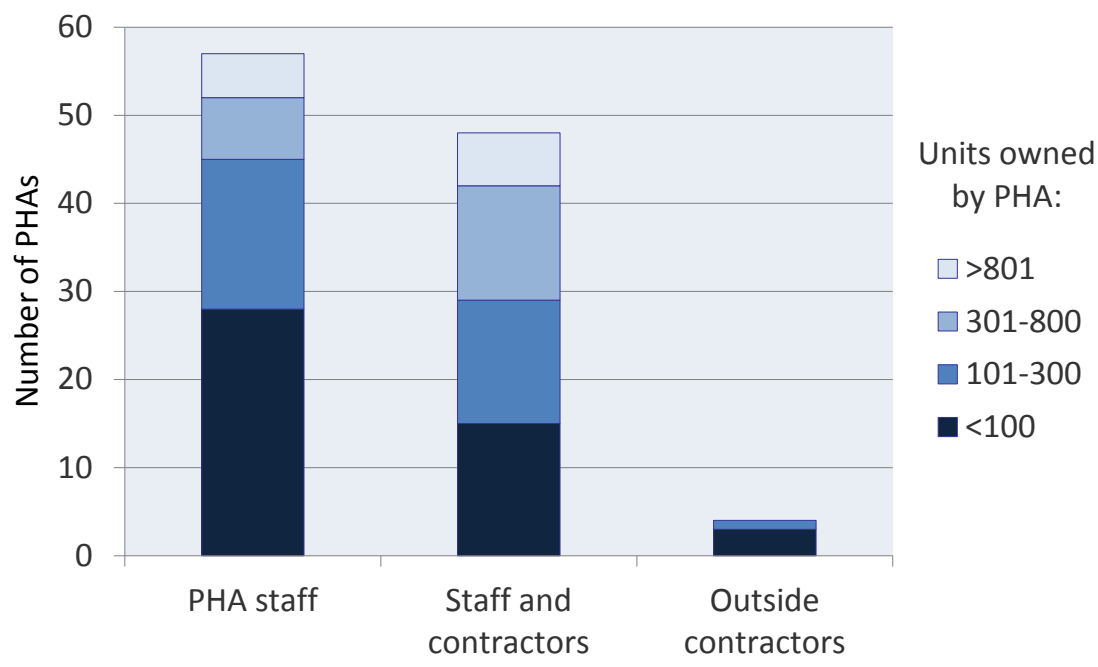

Figure 23. Repairs conducted by staff or contractors

\section{Unit Characteristics}

PHAs were asked to estimate the percentage of their units by building type (single-family detached or attached, multifamily low or high rise), material (wood frame or masonry), and age. The single most common unit type is single-family attached (40\%), although multifamily units outnumber single-family units overall (23\% low-rise and 34\% high-rise). Single-family detached homes are relatively rare $(3 \%)$. Figure 24 shows the breakdown of unit type by PHA size. 


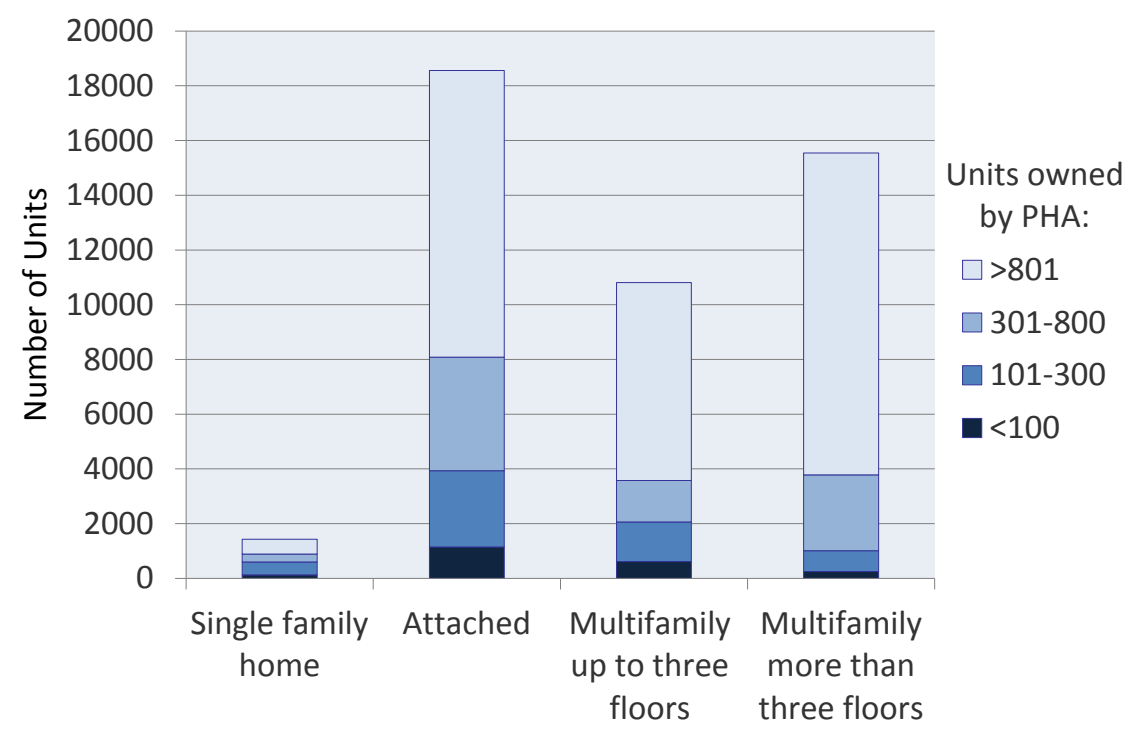

Figure 24. Unit type

Except for the larger PHAs (mostly in major cities), the vast majority of public housing represented by respondents is wood frame (Figure 25). Roof type tracks this distribution; a similar percentage has pitched roofs.

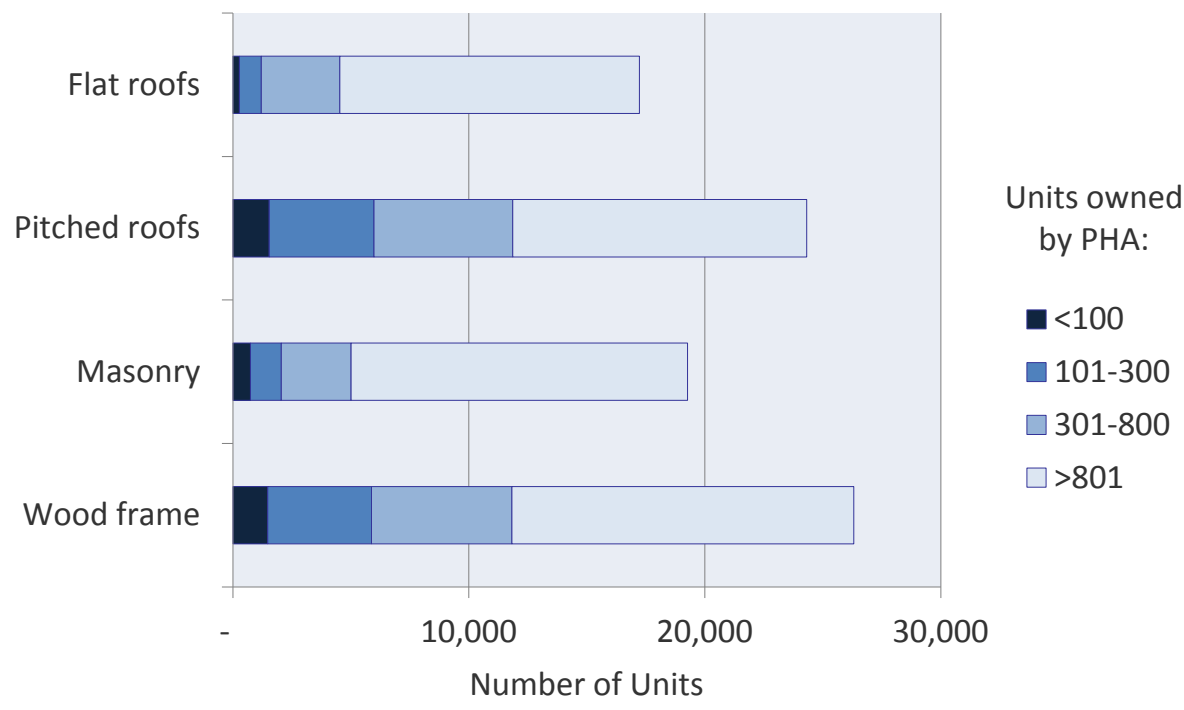

Figure 25. Building construction

Approximately $60 \%$ of the units are more than 30 years old, meaning they were built well before the stricter energy codes of recent years. As seen in Figure 26, smaller PHAs are less likely to have constructed units within the past 30 years. Eighty-four percent of units less than 30 years old are owned by PHAs with more than 800 units in the portfolio. 


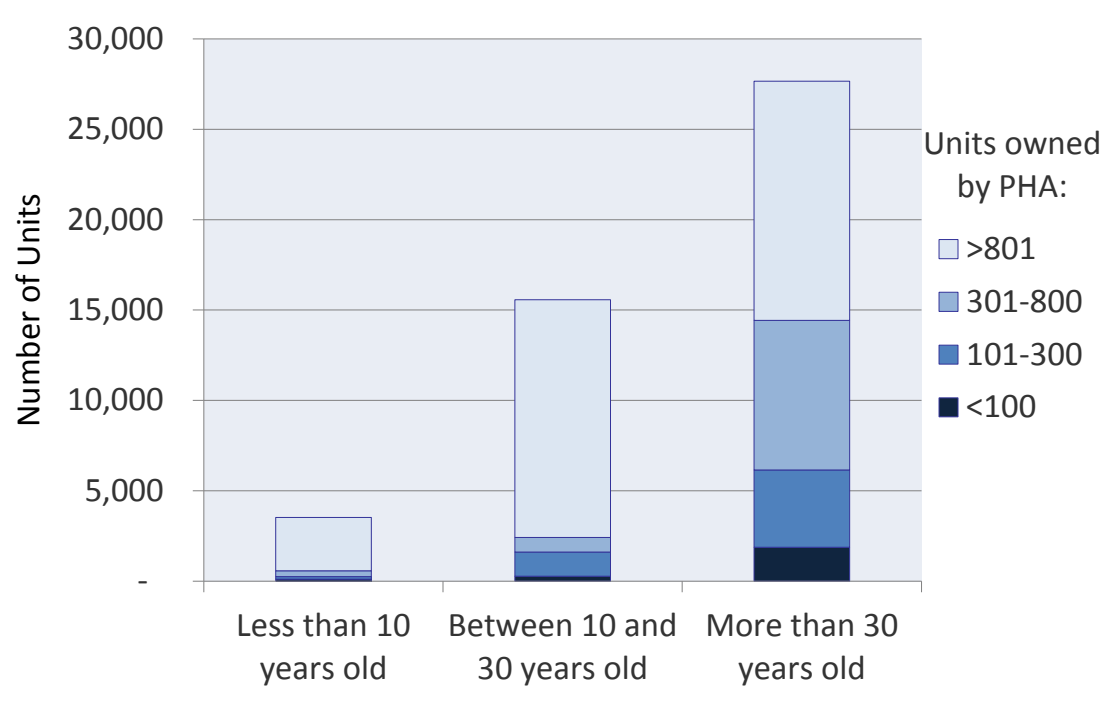

Figure 26. Building age

And about half of the PHA units surveyed have utilities submetered, sometimes just for electricity (Figure 27). In units that are not submetered (often multifamily high-rises), the PHA pays the utility bills.

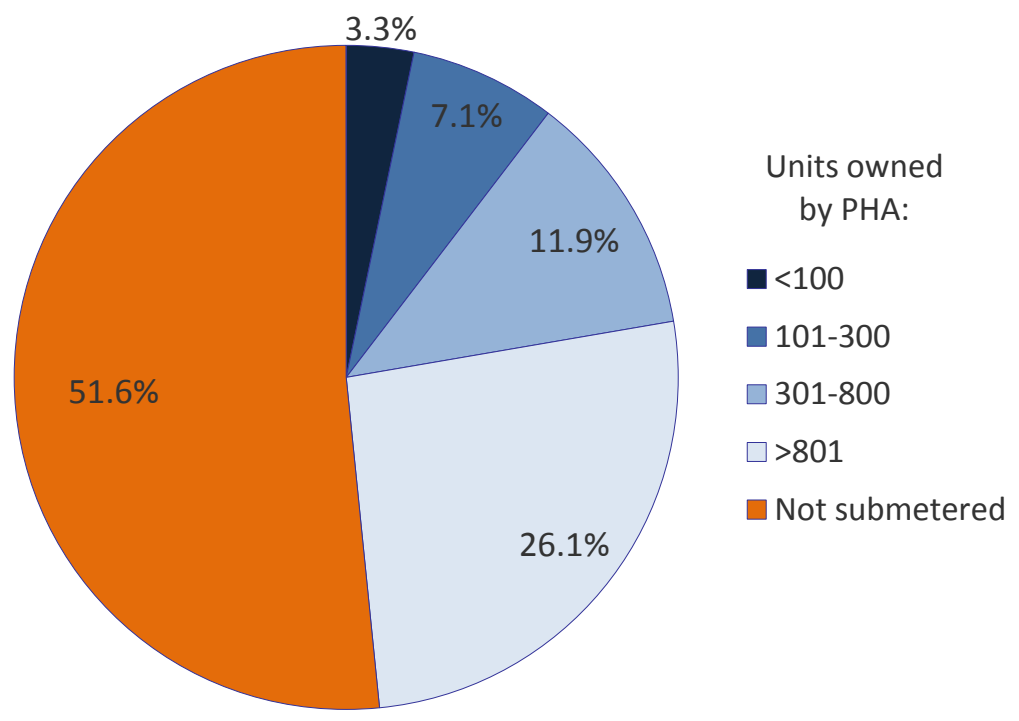

Figure 27. Buildings submetered

Gas furnaces are the dominant space-heating appliances among respondents, except for the larger PHAs, where boilers predominate in large multifamily buildings (Figure 28). Electric heating is fairly common overall (nearly $13 \%$ of units), and even more common in mixed or cold climate areas (20\% of units). For cooling, room ACs are common in multifamily buildings (Figure 29). Of the units represented by the respondent PHAs, about $4 \%$ had renewables installed, which were mainly in the larger PHAs (Figure 30). 


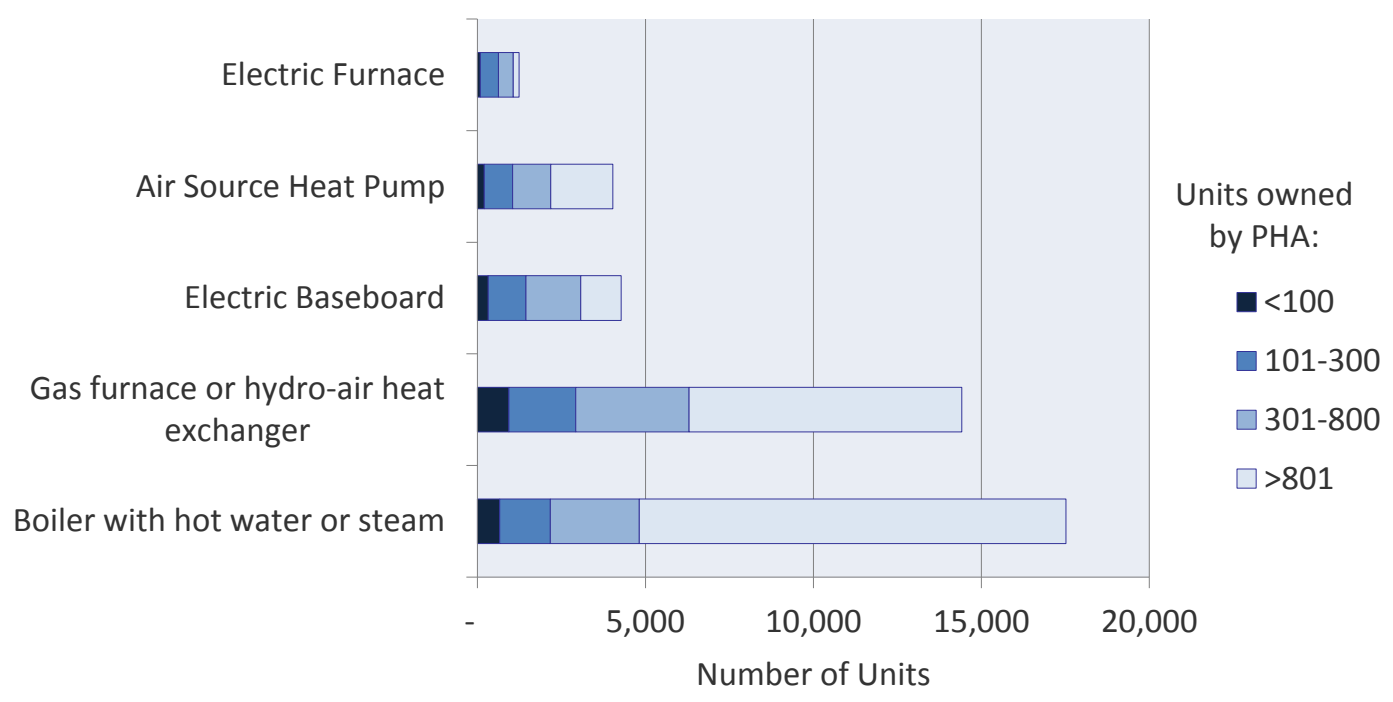

Figure 28. Heating system types

Room/window air conditioners

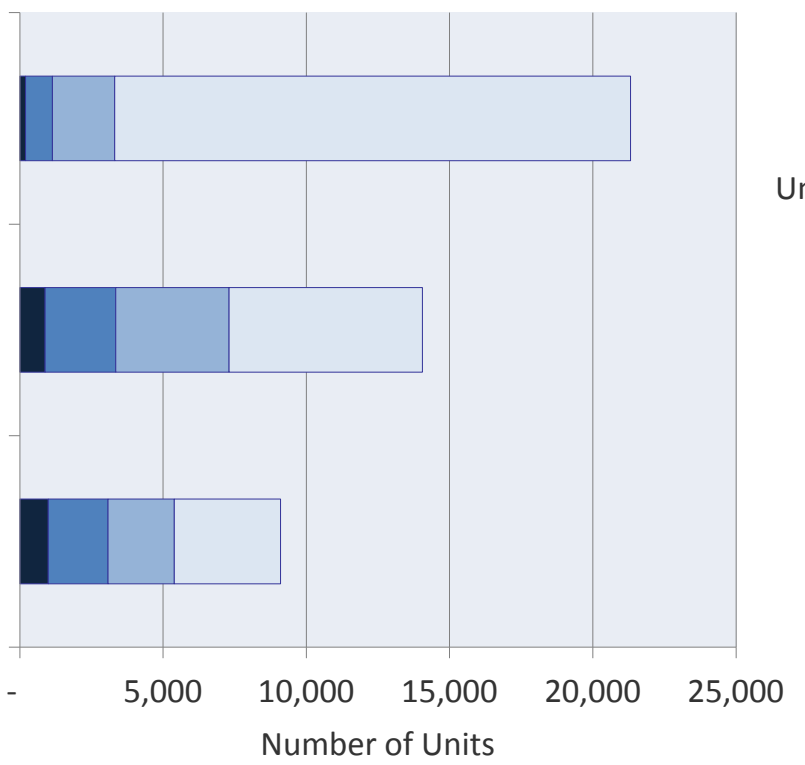

Units owned by PHA:

$\mathbf{0}<100$

101-300

$\square 301-800$

$\square>801$

Central air conditioning

Figure 29. Cooling system types 


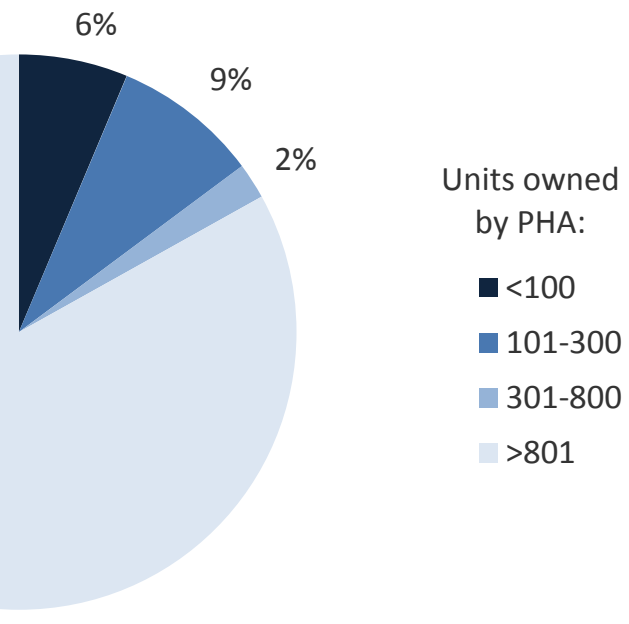

Figure 30. Use of renewables by PHA size, of the 4\% of PHA units using renewables

\section{Interest in Efficiency Measures}

Of the respondents, similar numbers of PHAs have weatherized all their units and have weatherized a very limited numbers of units; there are few PHAs in between (Figure 31). In addition, water efficiency is very important to many PHAs (Figure 32).

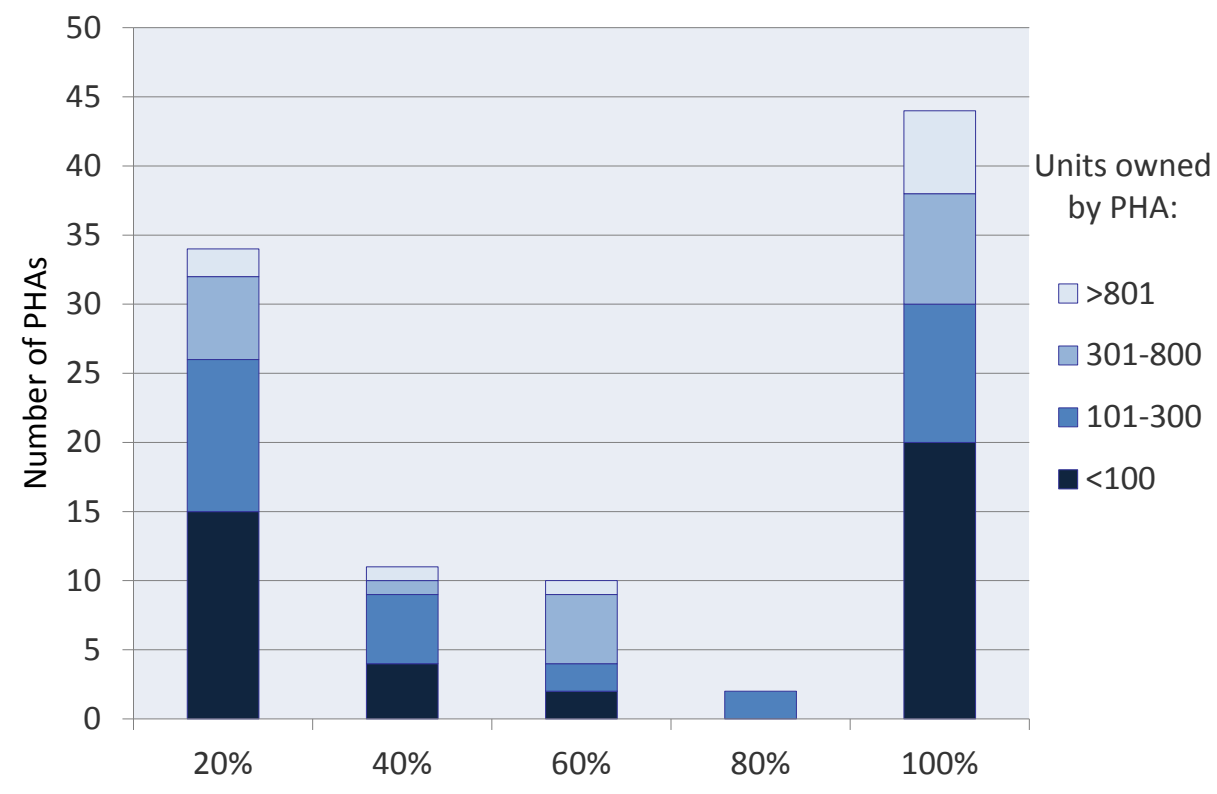

Figure 31. Percentage of units weatherized, by PHA size 


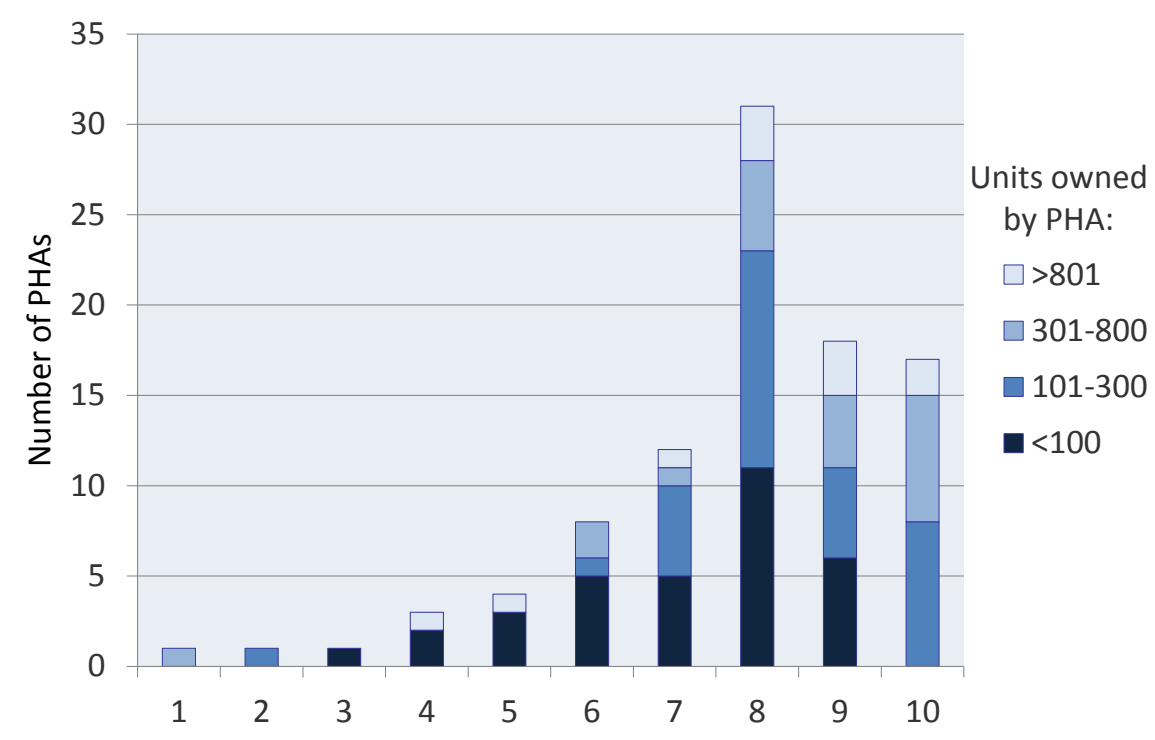

Figure 32. Interest in water conservation (1 = not important; 10 = very important)

Most PHAs are willing to invest to some degree on energy-efficiency measures; about one-third of respondents replied that they invest significant sums (Figure 33). Most have no payback criteria for energy-efficiency measures, although very small PHAs are less tolerant of long paybacks (Figure 34). HUD is the main source of energy-efficiency funding, but a large number of respondents indicated that they also self-fund improvements (Figure 35). EPCs are better suited to the larger PHAs that can meet the EPC minimum savings targets.

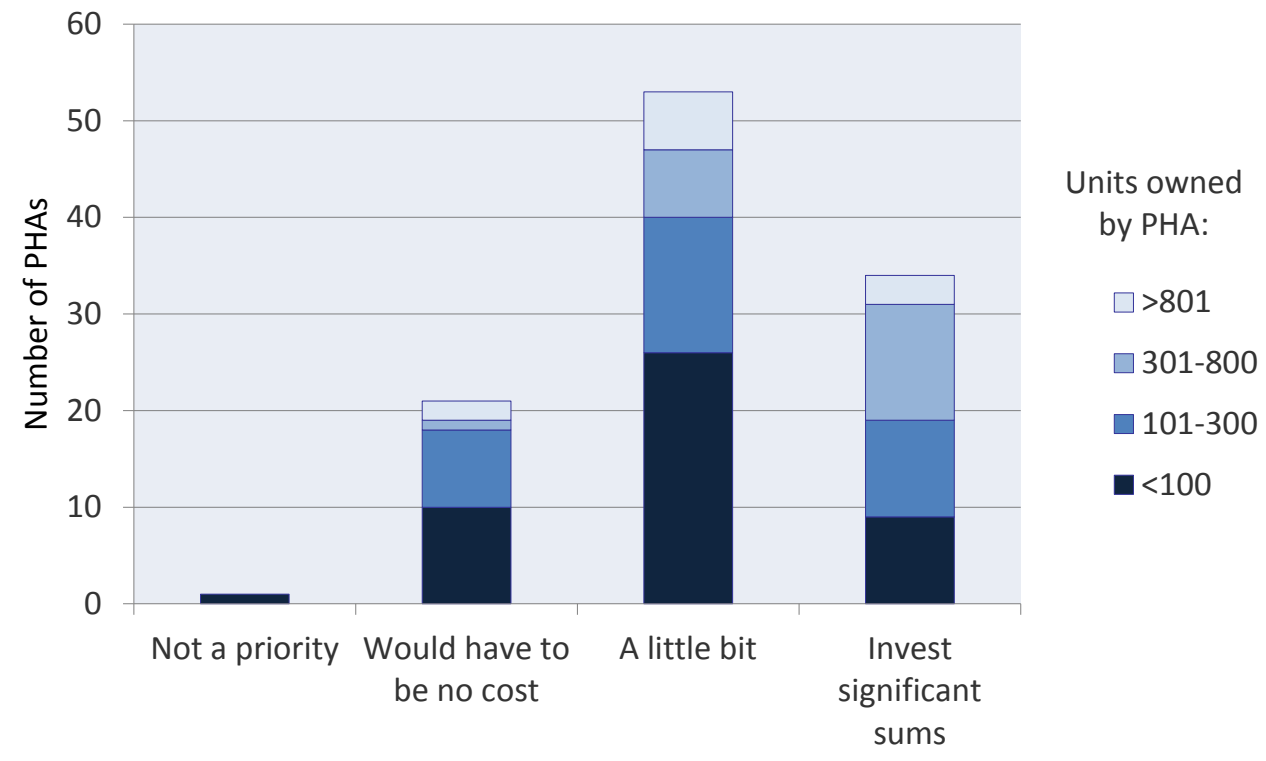

Figure 33. Spending on energy efficiency 


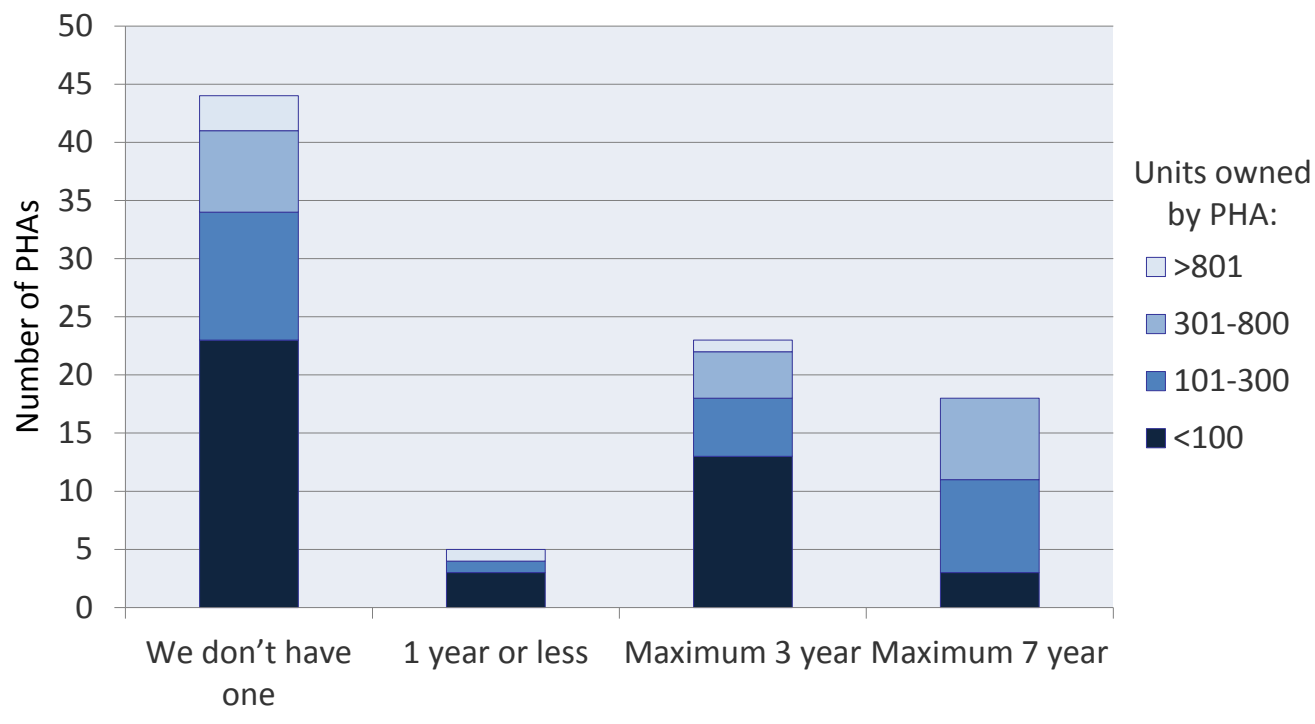

Figure 34. Energy-efficiency payback requirements

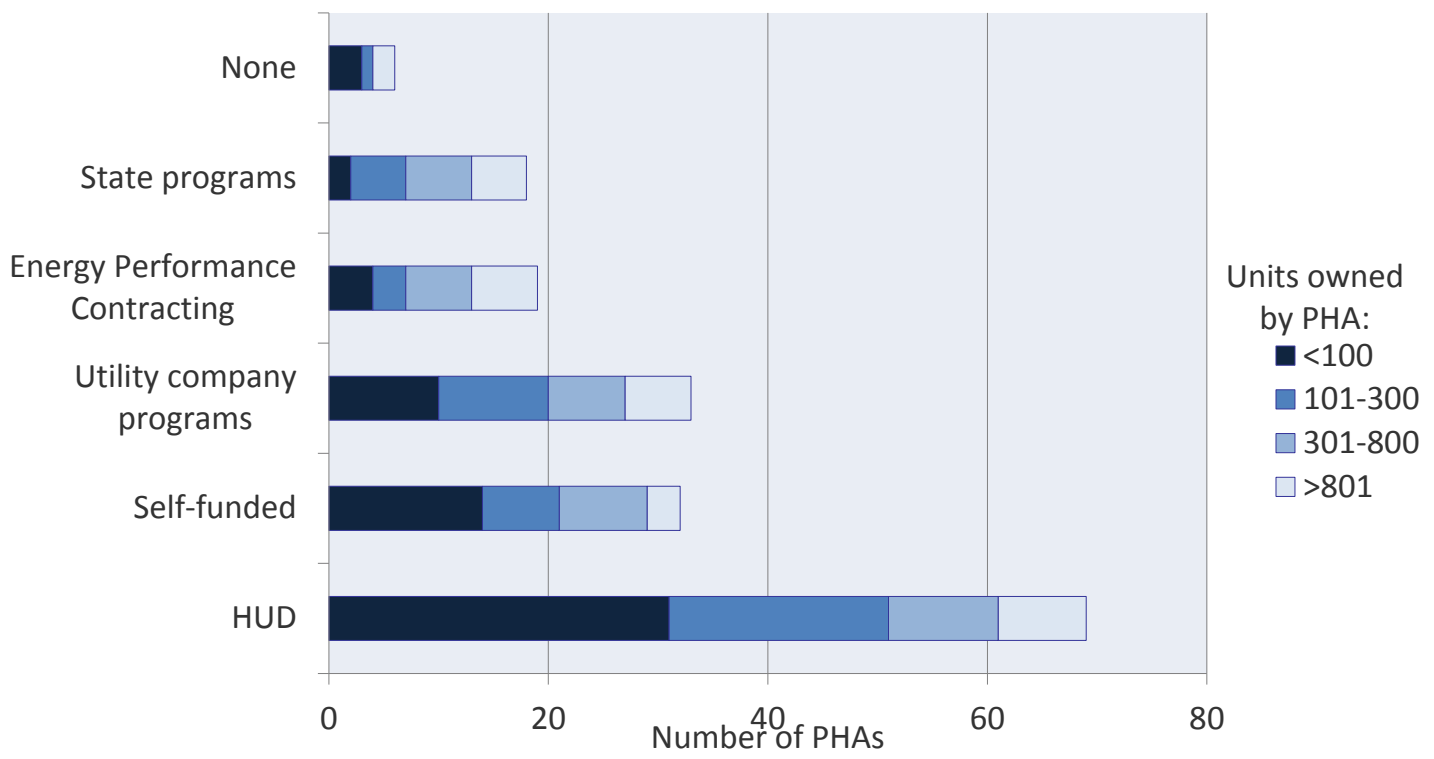

Figure 35. Energy-efficiency funding sources

Ninety-five percent of respondents said that having PHA staff implement energy-efficiency measures during turnover was of interest (Figure 36), although none of the PHA administrators spoken to during this process indicated that this was part of their standard operating procedures. (This latter question was not specifically asked on the survey.) More than three quarters of responding PHAs, representing all size categories, indicated an interest in working with Building America to develop energy-efficiency protocols for staff to implement at unit turnover (Figure $37)$. 


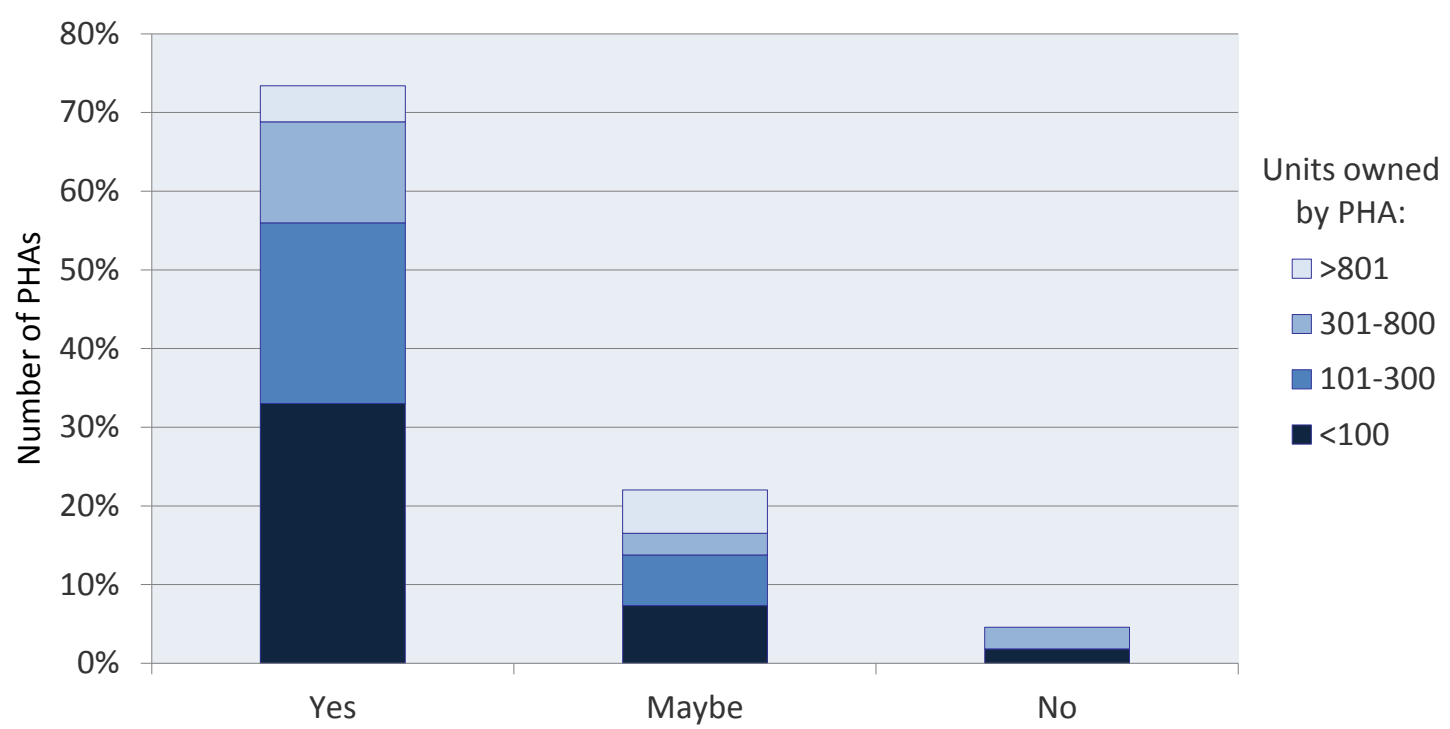

Figure 36. Interest in concept of staff implementation of energy efficiency

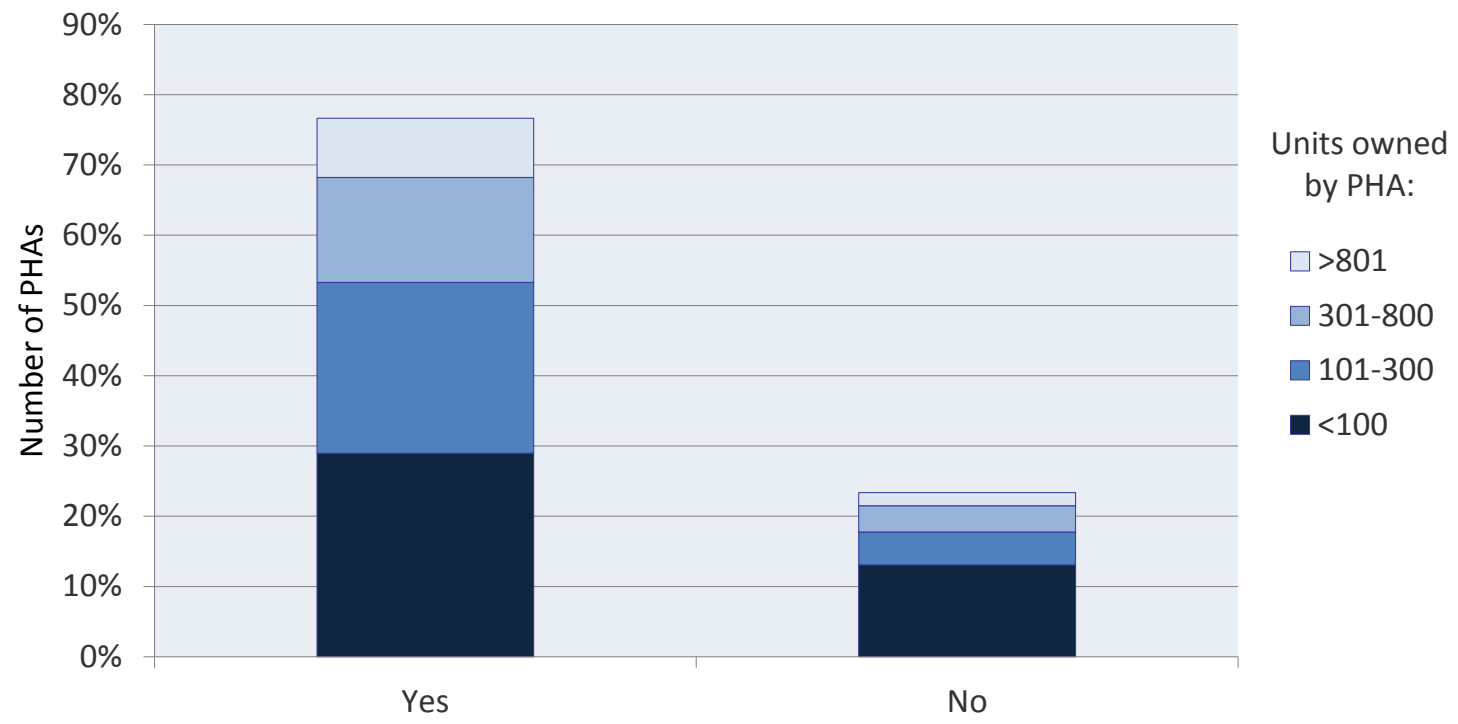

Figure 37. Interest in working with Building America 


\section{Appendix B: Survey Instrument}

\section{Public Housing Authority Survey Email Introduction}

Building America is a U.S. Department of Energy program that develops and evaluates technologies that improve the comfort, safety, durability, and energy efficiency of the nation's housing. The program is implemented by several multidisciplinary teams. The ARIES Collaborative is one of these teams. ARIES' unique focus is on reducing energy use in affordable housing, including public housing.

As part of our current work, ARIES is developing a set of cost-effective, energy efficient measures designed specifically for use by public housing authorities. The measures will be low or no-cost items and consider the financial and operational impact on PHAs. They will result in safer, healthier, more durable and comfortable homes and will provide a positive return on investment.

This project is starting with a survey of selected public housing agencies. The survey will help us assess the potential opportunity associated with implementing a set of energy improvements in the short period (several days) between occupancies. Selected PHAs will be invited to participate in field evaluations of the improvements planned for latter phases of the program.

Please follow this link to access the survey.

Thank you.

Jordan Dentz

ARIES Collaborative

\section{Public Housing Authority On-Line Survey}

Please answer as many of the following questions as possible, providing your best estimates. This survey should take approximately 15 minutes to complete. Exact numbers are not necessary.

1. Contact information

a. PHA name

b. Contact name

c. Contact job function/position at PHA (this survey is intended for personnel involved in facilities management or capital improvement)

d. Contact phone

e. Contact email

2. General information about your PHA

a. Number of developments owned/managed

b. Number of living units owned/managed

3. Operating issues

a. What is the typical annual resident turnover rates overall at your PHA? 
b. How many days do units typically remain vacant between occupancies?

c. At unit turnover what are the typical activities performed by your PHA (select one or more)?
i. Painting
ii. Cleaning
iii. Minor repairs
iv. Appliance replacement (if old)
v. Other - please list:

d. Who performs these activities between occupancies (select one or more)?

i. PHA staff

ii. Outside contractors

iii. Staff and contractors

e. How would you describe the overall skill level of your staff?

i. Modestly skilled: Able to perform simple maintenance tasks such as painting, filter changes, faucet drips, etc.

ii. Moderately skilled: Able to handle small improvement projects such as weather stripping, appliance replacement, wall repairs

iii. Highly skilled: Able to complete moderate to major renovations such as window replacement, plumbing repairs, electrical work.

f. Approximately what percentage of your living units have been weatherized in the past 10 years?

g. How much does your PHA pay annually for living unit utility costs (recognizing that these costs are reimbursed)?

h. How much does this represent as a percentage of your PHA operating budget?

4. Interest in energy efficiency

a. Recognizing that PHAs are reimbursed by HUD for most energy expenses, how interested is your PHA in reducing energy use at your sites?

i. Not a priority for us

ii. We would do it, but there would have to be no cost to us

iii. We spend a little bit on energy efficiency

iv. We invest significant sums in energy efficiency

b. What is your PHA's cost-effectiveness or payback criterion for deciding on energy efficiency investments?

i. We don't have one

ii. 1 year or less payback 
iii. Maximum 3 year payback

iv. Maximum 7 year payback

v. Other criteria:

c. What sources of funding does/has your PHA used for energy efficiency measures (select one or more)?

i. None (we have not done any)

ii. Self-funded

iii. HUD

iv. Energy Performance Contracting

v. Utility Company programs

vi. State programs

vii. Other

d. Is the idea of implementing during unit turnover low-cost energy efficiency measures that have proven and quantified effectiveness appealing to your PHA?

i. Yes. Please explain:

ii. Maybe. Please explain:

iii. No. Please explain:

e. How important is water conservation to your PHA?

i. Not on our radar (1) ..... A top priority for us (10)

5. Characteristics of the housing operated by your PHA

a. Approximate number of sites (not buildings) that have:

i. 1 living unit (i.e. a stand-alone single family home)

ii. 2-4 living units

iii. 5-50 living units

iv. More than 50 living units (i.e. could be one large building or 50 single family homes at one site)

b. Approximate percentage of living units that are in:

i. Single family homes

ii. Attached (townhome/duplex type) buildings

iii. Multifamily buildings up to three floors (multifamily buildings generally have common areas and/or living units stacked vertically)

iv. Multifamily buildings more than three floors

c. Approximate percentage of living units that are built with:

i. Wood frame construction (may have brick cladding) 
ii. Masonry construction

iii. Pitched roofs (with attics)

iv. Flat roofs

d. Approximate percentage of living units that have:

i. Electric baseboard heat

ii. Electric furnace (forced air) heat

iii. Air source heat pumps

iv. Gas furnace or hydro-to-air exchanger (with forced air distribution)

v. Boiler with hot water or steam distribution

vi. Central air conditioning

vii. Room/window air conditioners

viii. Renewables (PV, solar thermal or ground source heat pumps)

e. Approximate percentage of living units that are:

i. Less than 10 years old

ii. Between 10 and 30 years old

iii. More than 30 years old

f. Approximate percentage of living units that are individually (sub)metered for utilities (whether or not paid for by the resident).

6. Building America

a. Thank you for participating in this survey. Would you be interested in discussing Building America research opportunities such as field evaluations of the energy efficiency protocols at your PHA? 


\section{Appendix C: Islip Housing Authority Implementation Guidelines \\ Islip Housing Authority: Unit Turnover Protocol Checklist}

Address and apartment number:

\begin{tabular}{|c|c|c|c|}
\hline & ITEM & COMPLETE & N/A \\
\hline \multirow{12}{*}{ 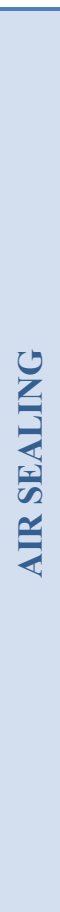 } & $\begin{array}{l}\text { Sample units to check that air flow is not near lower allowable limit according } \\
\text { to ASHRAE } 62-89 \text { unless mechanical ventilation is planned. If planning to } \\
\text { tighten units housing combustion equipment, consult with qualified personnel } \\
\text { to confirm that NFPA-54 standards are met and that combustion appliances are } \\
\text { supplied with adequate combustion and dilution air and are vented properly }\end{array}$ & & \\
\hline & Seal bottom of walls to floor if carpet removed and/or where accessible & & \\
\hline & Seal plumbing penetrations (all walls): shower heads, under sinks, water heater & & \\
\hline & $\begin{array}{l}\text { Seal electrical penetrations (all walls, ceilings): outlets, switches, behind } \\
\text { oven/fridge, telephone box, intercom, in closet ceilings/floors }\end{array}$ & & \\
\hline & Re-grout tile floors and walls & & \\
\hline & Seal at base of bathtubs, toilets & & \\
\hline & Seal ceiling penetrations at lighting fixtures & & \\
\hline & Seal exhaust fan housing and ducts boots to ceiling & & \\
\hline & Replace entry door weather stripping if necessary & & \\
\hline & Caulk around entry door frame and windows & & \\
\hline & Foam inside door latches (all doors) & & \\
\hline & Seal at stair treads and risers & & \\
\hline \multirow{3}{*}{$\stackrel{u}{u}$} & Clean AC filter if necessary & & \\
\hline & Seal around $\mathrm{AC}$ unit & & \\
\hline & Clean/replace air handler filter if present & & \\
\hline \multirow{5}{*}{ 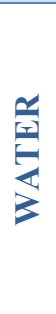 } & Check and adjust hot water temperature & & \\
\hline & Insulate hot water tank & & \\
\hline & Insulate exposed DHW pipes & & \\
\hline & Correct faucet/shower drips & & \\
\hline & Check shower flow and install low-flow showerhead if necessary & & \\
\hline \multirow{4}{*}{$\stackrel{U}{\underline{E}}$} & Check and fix attic insulation & & \\
\hline & Seal wall top plates in attic if accessible & & \\
\hline & Add attic hatch insulation & & \\
\hline & Add attic hatch gasket & & \\
\hline \multirow{2}{*}{ 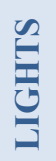 } & Check and replace light bulbs & & \\
\hline & Install LED surface mount light fixtures & & \\
\hline
\end{tabular}




\begin{tabular}{|c|c|c|c|}
\hline & ITEM & COMPLETE & N/A \\
\hline \multirow{3}{*}{ 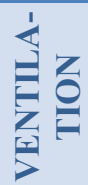 } & Check bath and kitchen exhaust fan flow using the simple credit card method ${ }^{4}$ & & \\
\hline & Clean bath and kitchen exhaust fans & & \\
\hline & Check bath and kitchen exhaust fan condition & & \\
\hline
\end{tabular}

Date completed:

Signature of responsible staff:

Name:

${ }^{4}$ See NYSERDA's “Homeowner's Guide to Ventilation" (NYSERDA 2013). 1.5" credit-card deflection corresponds with about 25 CFM, 2" corresponds with 35 CFM, and 2.5" corresponds with around 48 CFM (Holladay 2015). 


\section{Islip Housing Authority: Unit Turnover Protocol and Guidelines}

The following guidelines are intended for use when apartments are prepared for new residents. All activities are intended to be low-cost, achievable by IHA staff with readily available tools and materials, and fit within the time available during unit turnover. The guidelines are organized by topic and include information on location, how to accomplish the task, materials required, and photos illustrating typical conditions

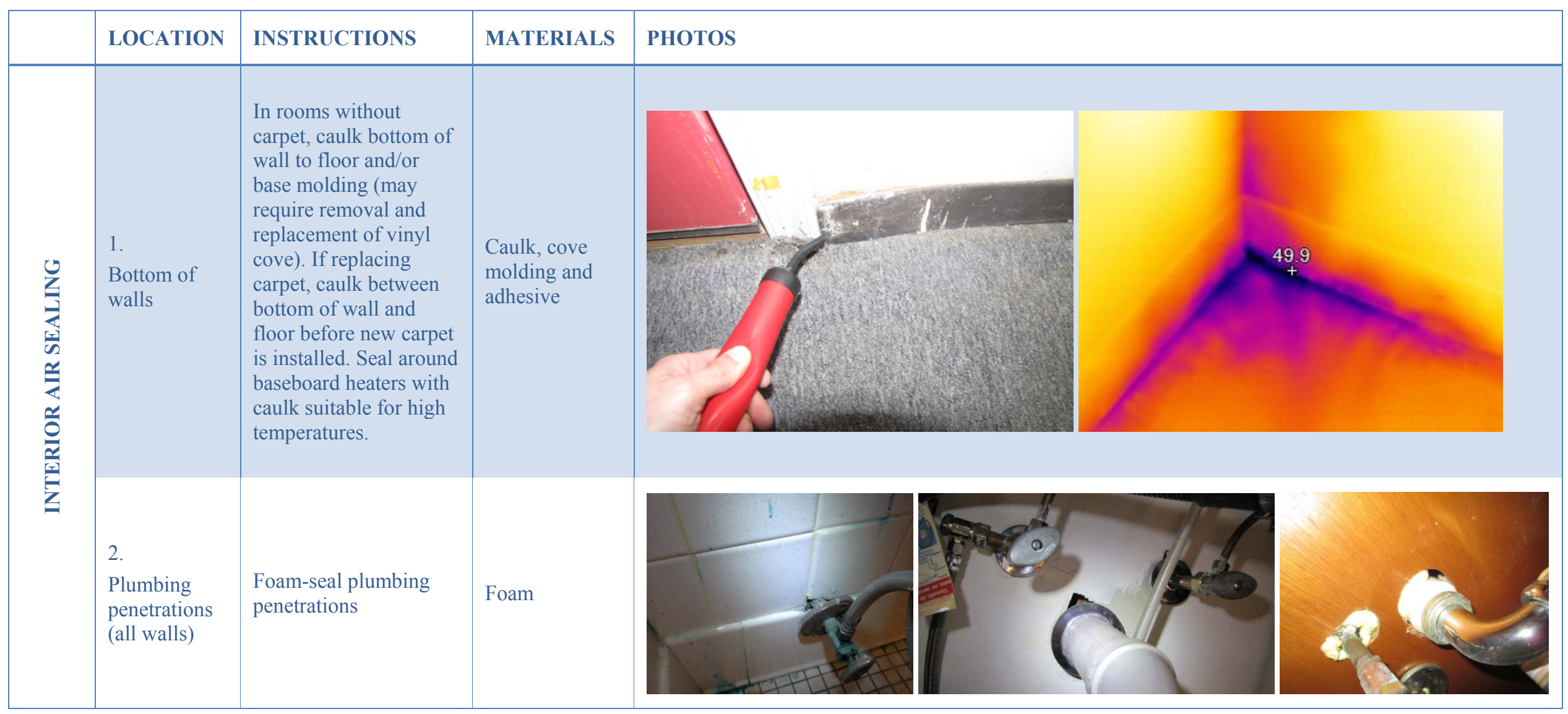




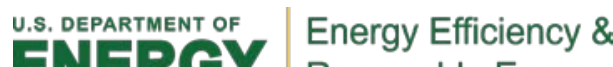

ENERGY Renewable Energy

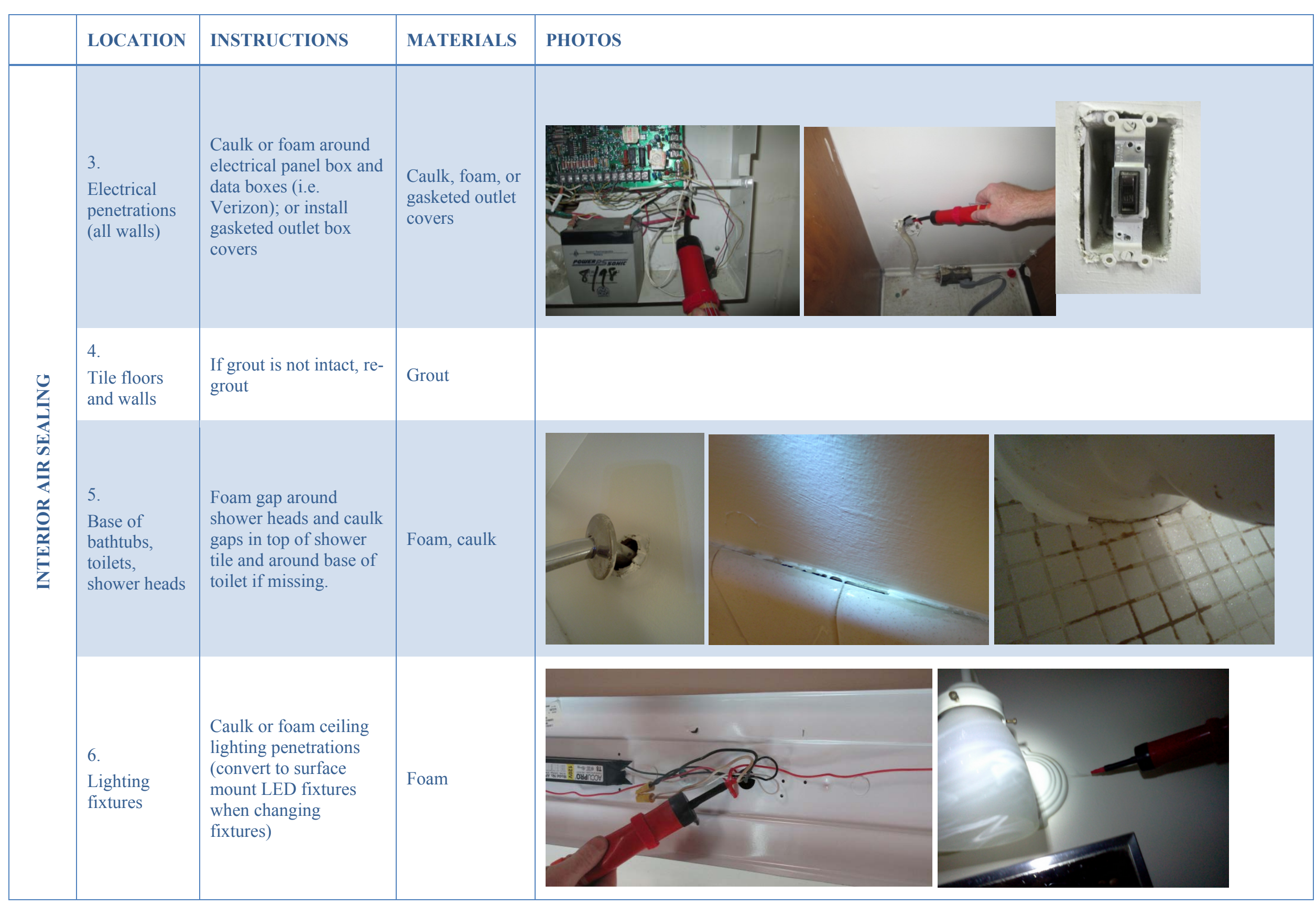




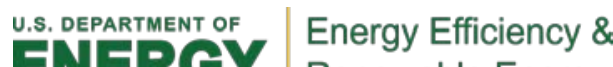

ENERCY Renewable Energy

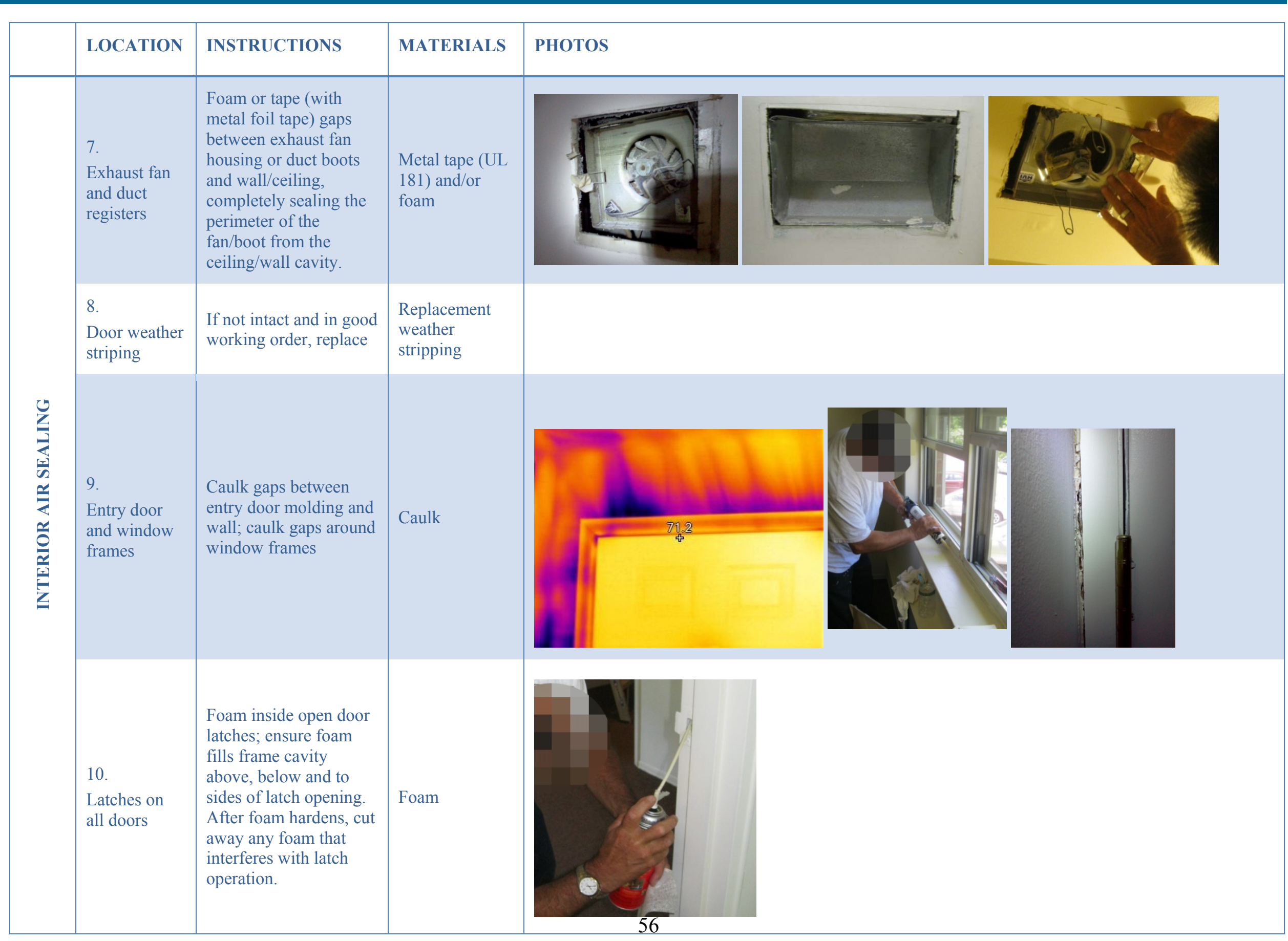


U.S. DEPARTMENT OF | Energy Efficiency \&

ENERCY Renewable Energy

\begin{tabular}{|l|l|l|l|l|}
\hline & LOCATION & INSTRUCTIONS & MATERIALS & PHOTOS \\
\hline $\begin{array}{l}11 . \\
\text { Stair treads } \\
\text { and risers }\end{array}$ & $\begin{array}{l}\text { Caulk gaps around } \\
\text { risers, treads and } \\
\text { stringers and between } \\
\text { stringers and wall. }\end{array}$ & Caulk \\
\hline $\begin{array}{l}12 . \\
\text { AC filter }\end{array}$ & $\begin{array}{l}\text { Check and clean if } \\
\text { necessary }\end{array}$ & N/A \\
\hline $\begin{array}{l}\text { 13. } \\
\text { AC unit }\end{array}$ & $\begin{array}{l}\text { Tape/gasket gaps } \\
\text { between AC and sleeve }\end{array}$ & $\begin{array}{l}\text { Tape or gasket } \\
\text { if ACsent }\end{array}$ & $\begin{array}{l}\text { Clean or replace filter if } \\
\text { dirty }\end{array}$ & $\begin{array}{l}\text { Vacuum or } \\
\text { compressed air; } \\
\text { feplacement } \\
\text { filter }\end{array}$ \\
\hline $\begin{array}{l}14 . \\
\text { Air handler } \\
\text { filter }\end{array}$ & & \\
\hline
\end{tabular}


U.s. DEPARTMENT OF | Energy Efficiency \&

ENERCY Renewable Energy

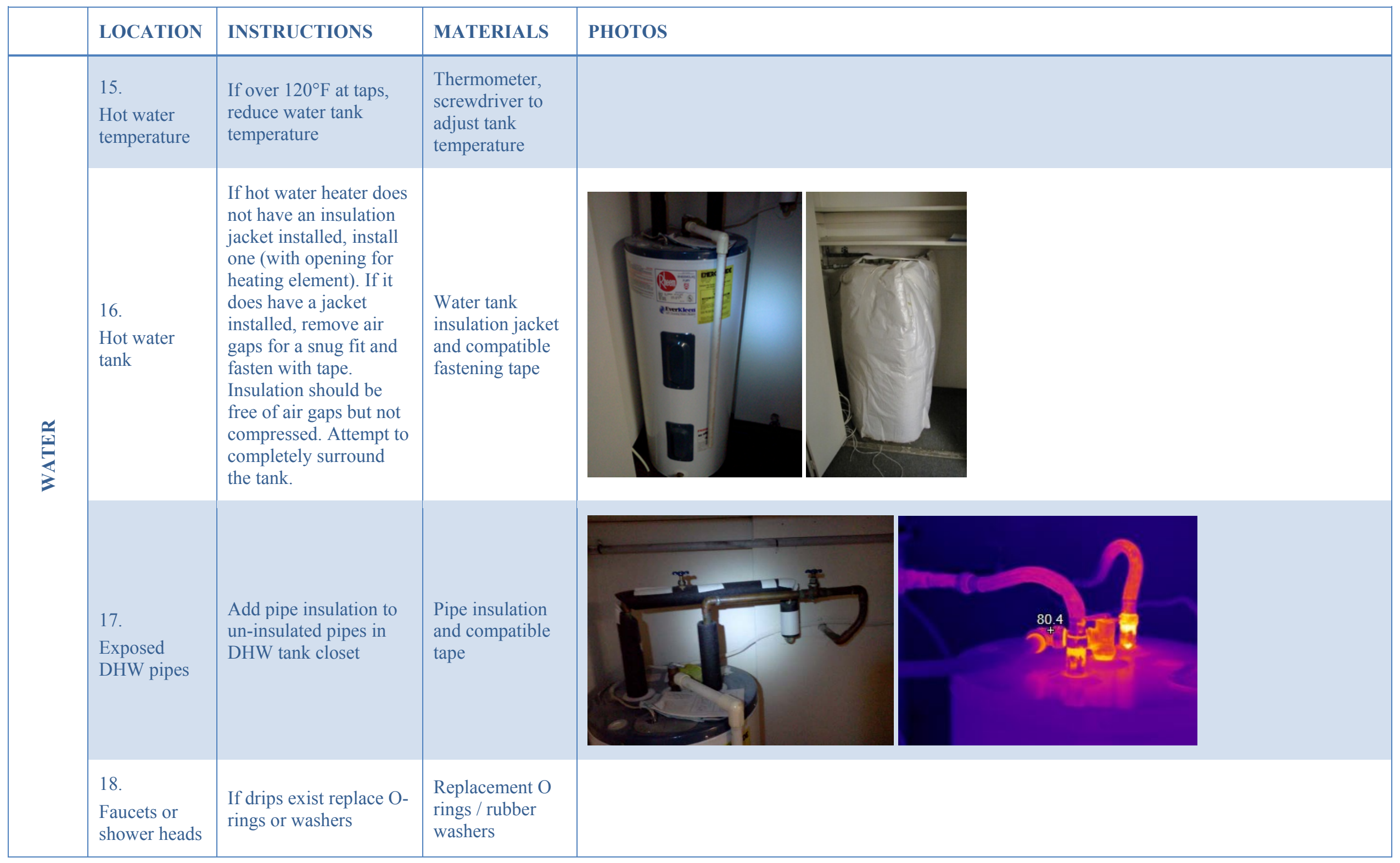


U.s. DEPARTMENT OF Energy Efficiency \&

ENERCY Renewable Energy

\begin{tabular}{|c|c|c|c|c|}
\hline & LOCATION & INSTRUCTIONS & MATERIALS & PHOTOS \\
\hline$\frac{x}{2}$ & $\begin{array}{l}19 . \\
\text { Shower head }\end{array}$ & $\begin{array}{l}\text { Ensure low-flow } \\
\text { showerhead installed - } \\
\text { if it takes less than } 20 \\
\text { seconds to fill a one } \\
\text { gallon container, } \\
\text { replace with low-flow } \\
\text { showerhead }\end{array}$ & $\begin{array}{l}\text { Low-flow } \\
\text { shower head, } \\
\text { thread sealant / } \\
\text { compound }\end{array}$ & \\
\hline \multirow{2}{*}{ 崔 } & $\begin{array}{l}20 . \\
\text { Attic } \\
\text { insulation } \\
\text { depth and } \\
\text { distribution }\end{array}$ & $\begin{array}{l}\text { Check that ceiling } \\
\text { insulation is dispersed } \\
\text { evenly without gaps, is } \\
\text { free of water damage, } \\
\text { and covers rafters and } \\
\text { other framing members } \\
\text { fully to the exterior } \\
\text { walls. Re-arrange } \\
\text { insulation or } \\
\text { supplement if } \\
\text { necessary. }\end{array}$ & $\begin{array}{l}\text { Flashlight, attic } \\
\text { insulation }\end{array}$ & \\
\hline & $\begin{array}{l}21 . \\
\text { Wall top } \\
\text { plates } \\
\text { intersection } \\
\text { with attic }\end{array}$ & $\begin{array}{l}\text { When/if replacing attic } \\
\text { insulation over framed } \\
\text { walls, foam } \\
\text { penetrations where } \\
\text { accessible }\end{array}$ & Foam, flashlight & \\
\hline
\end{tabular}


U.S. DEPARTMENT OF | Energy Efficiency \&

ENERCY Renewable Energy

\begin{tabular}{|c|c|c|c|c|}
\hline & LOCATION & INSTRUCTIONS & MATERIALS & PHOTOS \\
\hline \multirow{2}{*}{ 导 } & $\begin{array}{l}22 . \\
\text { Attic hatch } \\
\text { insulation }\end{array}$ & $\begin{array}{l}\text { Glue } 2 \text { " rigid foam to } \\
\text { back of hatch }\end{array}$ & $\begin{array}{l}\text { Rigid foam } \\
\text { board and } \\
\text { construction } \\
\text { adhesive }\end{array}$ & \\
\hline & $\begin{array}{l}23 . \\
\text { Attic hatch air } \\
\text { leakage }\end{array}$ & $\begin{array}{l}\text { Add gasket/weather } \\
\text { stripping to seal hatch } \\
\text { to opening }\end{array}$ & $\begin{array}{l}\text { Gasket or } \\
\text { weather } \\
\text { stripping }\end{array}$ & \\
\hline \multirow{2}{*}{ 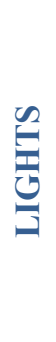 } & $\begin{array}{l}24 . \\
\text { Light bulbs }\end{array}$ & $\begin{array}{l}\text { Replace incandescent } \\
\text { bulbs with standard or } \\
\text { warm tone CFLs }\end{array}$ & CFLs & \\
\hline & $\begin{array}{l}25 . \\
\text { Pin-based } \\
\text { fluorescent } \\
\text { lamps }\end{array}$ & $\begin{array}{l}\text { Consider replacing } \\
\text { with LED when } \\
\text { replacing fixtures }\end{array}$ & LED fixtures & \\
\hline
\end{tabular}




\begin{tabular}{|c|c|c|c|c|}
\hline & LOCATION & INSTRUCTIONS & MATERIALS & PHOTOS \\
\hline 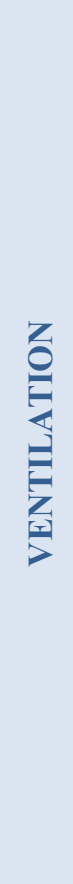 & $\begin{array}{l}\begin{array}{l}26 . \\
\text { Bath and kitchen } \\
\text { exhaust fans } \\
\text { (check flow) }\end{array} \\
\\
27 . \\
\begin{array}{l}\text { Bath and kitchen } \\
\text { exhaust fans } \\
\text { (check grime } \\
\text { build-up) }\end{array} \\
28 \\
\begin{array}{l}\text { Bath and kitchen } \\
\text { exhaust fans } \\
\text { (check condition) }\end{array}\end{array}$ & $\begin{array}{l}\text { Check fan flow. See } \\
\text { NYSERDA's } \\
\text { "Homeowner's } \\
\text { Guide to } \\
\text { Ventilation" } \\
\text { (http://www.nyserda. } \\
\text { ny.gov/ /media/Files/ } \\
\text { EERP/Residential/ho } \\
\text { me_vent_guide.pdf?s } \\
\text { c_database=web) } \\
\\
\text { If excessively dirty, } \\
\text { vacuum fan blades, } \\
\text { motor, and housing } \\
\text { (wipe with rag before } \\
\text { air sealing) } \\
\\
\text { If fan makes } \\
\text { irregular mechanical } \\
\text { noises, then replace }\end{array}$ & $\begin{array}{l}\text { See } \\
\text { NYSERDA } \\
\text { guide } \\
\text { (attached) } \\
\text { Vacuum, rags }\end{array}$ & \\
\hline
\end{tabular}




\section{Appendix D: Raleigh Housing Authority Implementation Guidelines}

\section{Raleigh Housing Authority: Unit Turnover Protocol Checklist}

\begin{tabular}{|c|c|c|c|}
\hline & ITEM & COMPLETE & N/A \\
\hline \multirow{12}{*}{ 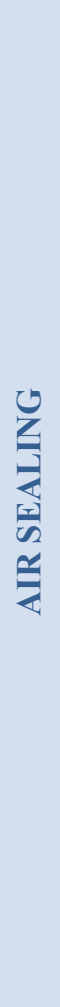 } & $\begin{array}{l}\text { Sample units to check that air flow is not near lower allowable limit } \\
\text { according to ASHRAE } 62-89 \text { unless mechanical ventilation is planned If } \\
\text { planning to tighten units housing combustion equipment, consult with } \\
\text { qualified personnel to confirm that NFPA- } 54 \text { standards are met and that } \\
\text { combustion appliances are supplied with adequate combustion and } \\
\text { dilution air and are vented properly }\end{array}$ & & \\
\hline & Seal bottom of walls to floor if carpet removed and/or where accessible & & \\
\hline & $\begin{array}{l}\text { Seal plumbing penetrations (all walls): shower heads, under sinks, water } \\
\text { heater; inspect and seal plumbing access as necessary. }\end{array}$ & & \\
\hline & $\begin{array}{l}\text { Seal electrical penetrations (all walls, ceilings): outlets, switches, behind } \\
\text { oven/fridge, telephone box, intercom, in closet ceilings/floors }\end{array}$ & & \\
\hline & Re-caulk tile floors and walls using bath and tile caulk. & & \\
\hline & Seal at base of bathtubs, toilets & & \\
\hline & Seal ceiling penetrations at lighting fixtures & & \\
\hline & Seal exhaust fan housing and ducts boots to ceiling & & \\
\hline & Replace entry door weather stripping if necessary & & \\
\hline & Caulk around entry door frame and windows; be sure to get the tops. & & \\
\hline & Foam inside door latches (all doors) & & \\
\hline & Seal at stair treads and risers & & \\
\hline \multirow{3}{*}{$\stackrel{u}{\gtrless}$} & Replace louvered mechanical room door with solid, weather stripped door & & \\
\hline & Seal air handler cabinet and return ductwork and filter slot. & & \\
\hline & Clean/replace air handler filter; clean return air grille & & \\
\hline \multirow{5}{*}{ 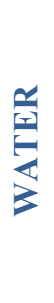 } & Check and adjust hot water temperature & & \\
\hline & Insulate hot water tank & & \\
\hline & Insulate exposed DHW pipes & & \\
\hline & Correct faucet/shower drips & & \\
\hline & Check shower flow and install low-flow showerhead if necessary & & \\
\hline \multirow{4}{*}{$\stackrel{U}{\underline{E}}$} & Check and fix attic insulation & & \\
\hline & $\begin{array}{l}\text { Seal wall top plates and wire penetrations within reach in attic if } \\
\text { accessible }\end{array}$ & & \\
\hline & Add attic hatch insulation & & \\
\hline & Add attic hatch gasket & & \\
\hline \multirow{2}{*}{ 岂 } & Check and replace light bulbs & & \\
\hline & Install LED surface mount light fixtures & & \\
\hline
\end{tabular}




\begin{tabular}{|l|l|l|}
\hline & $\begin{array}{l}\text { Check bath and kitchen exhaust fan flow using the simple credit card } \\
\text { method }^{5}\end{array}$ & \\
\hline & Clean bath and kitchen exhaust fans & \\
\hline Check bath and kitchen exhaust fan condition & \\
\hline
\end{tabular}

Address and apartment number:

Date completed:

Signature of responsible staff:

Name:

\footnotetext{
${ }^{5}$ See NYSERDA's “Homeowner's Guide to Ventilation" (NYSERDA 2013). 1.5" credit-card deflection corresponds with about 25 CFM, 2" corresponds with 35 CFM, and 2.5" corresponds with around 48 CFM (Holladay, 2015).
} 


\section{Raleigh Housing Authority: Unit Turnover Protocol and Guidelines}

The following guidelines are intended for use when apartments are prepared for new residents. All activities are intended to be low-cost, achievable by RHA staff with readily available tools and materials, and fit within the time available during unit turnover. The guidelines are organized by topic and include information on location, how to accomplish the task, materials required and photos illustrating typical conditions

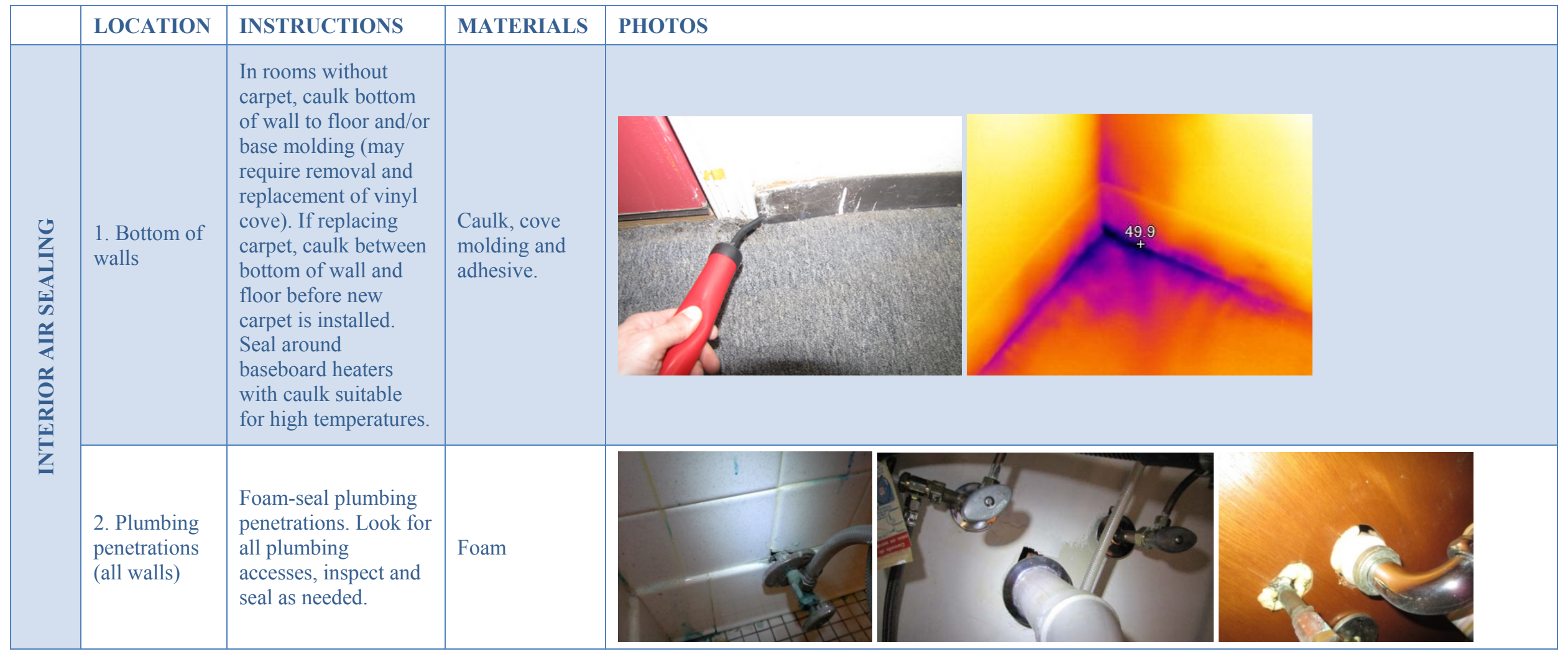


U.s. DEPARTMENT OF | Energy Efficiency \&

ENERCY Renewable Energy

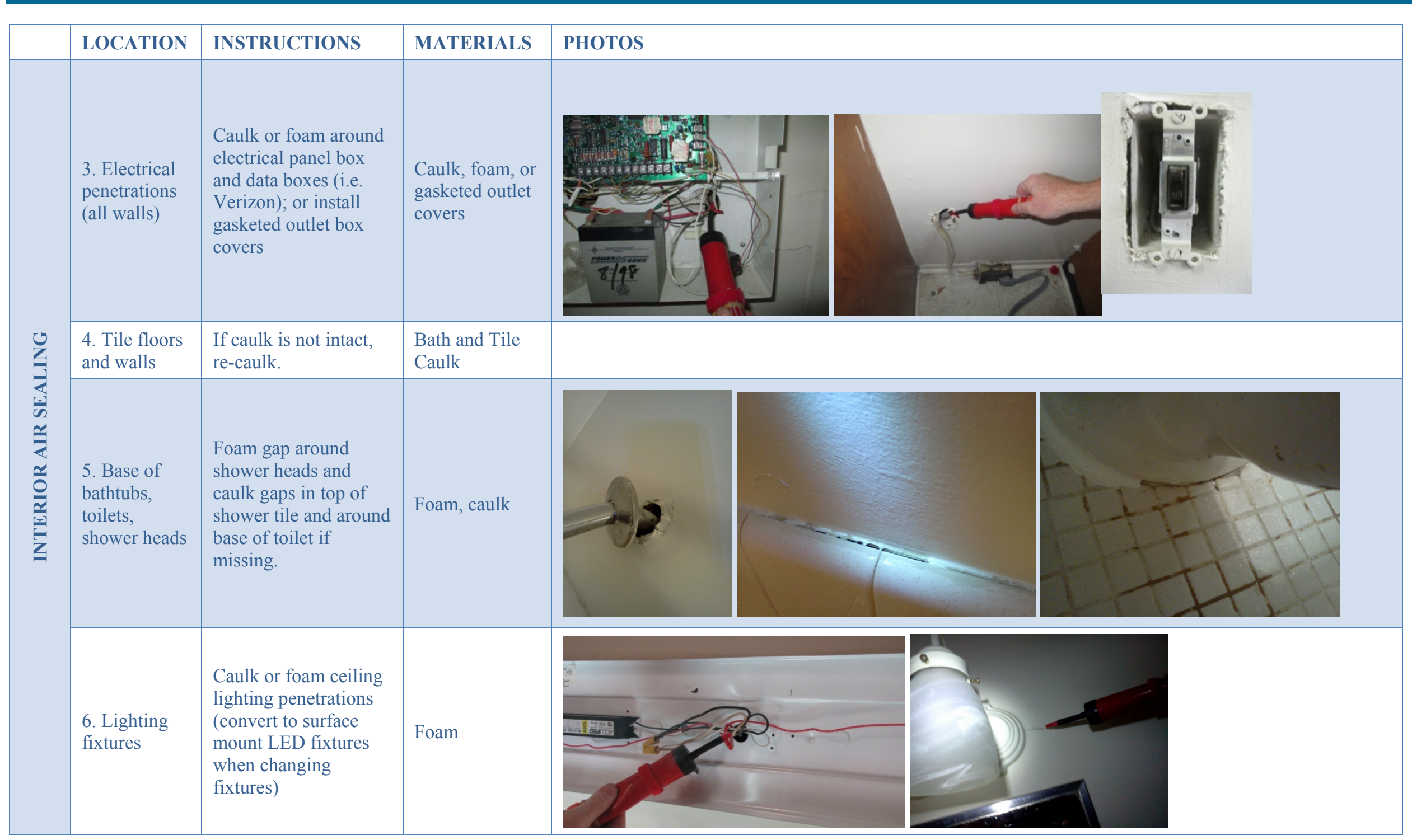


U.s. DEPARTMENT OF Energy Efficiency \&

ENERCY Renewable Energy

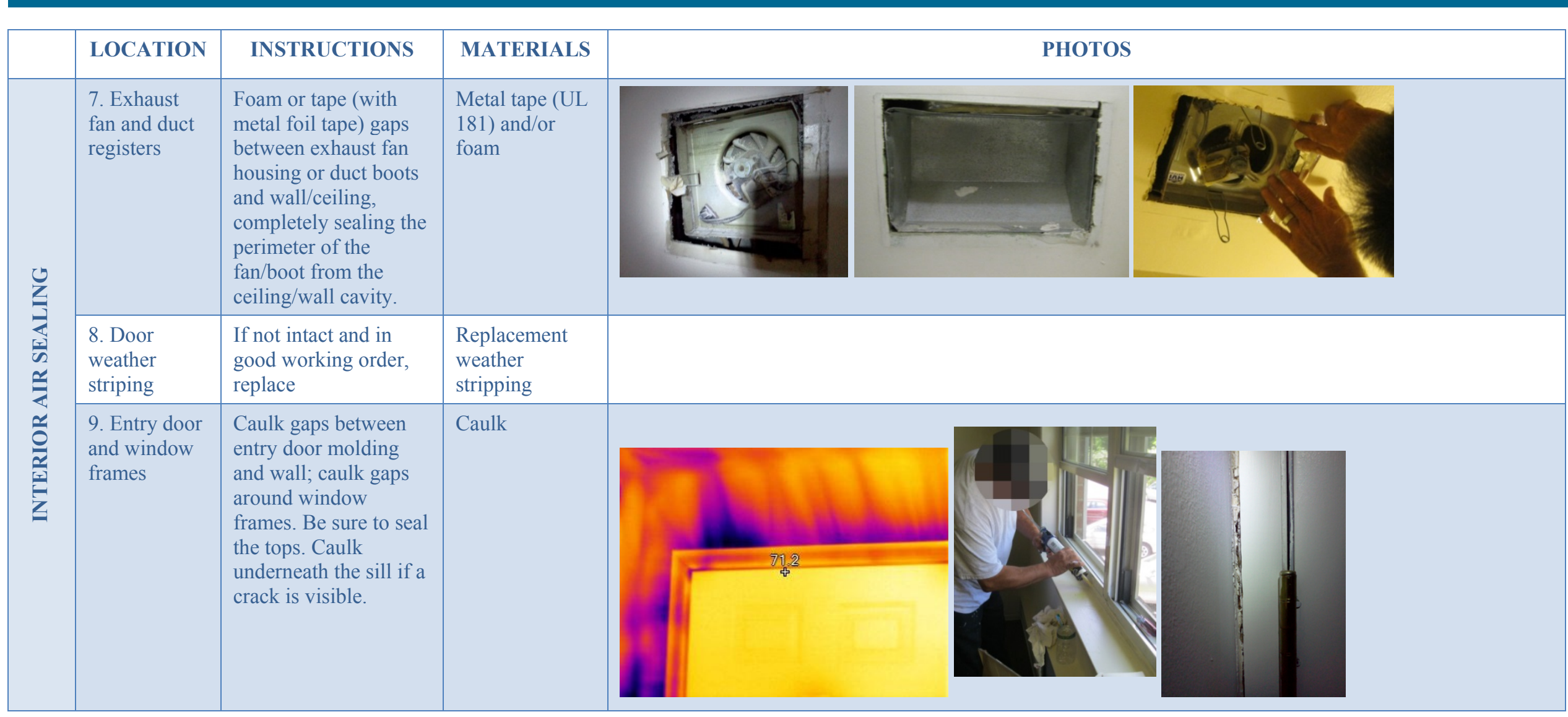


U.S. DEPARTMENT OF | Energy Efficiency \&

ENERCY Renewable Energy

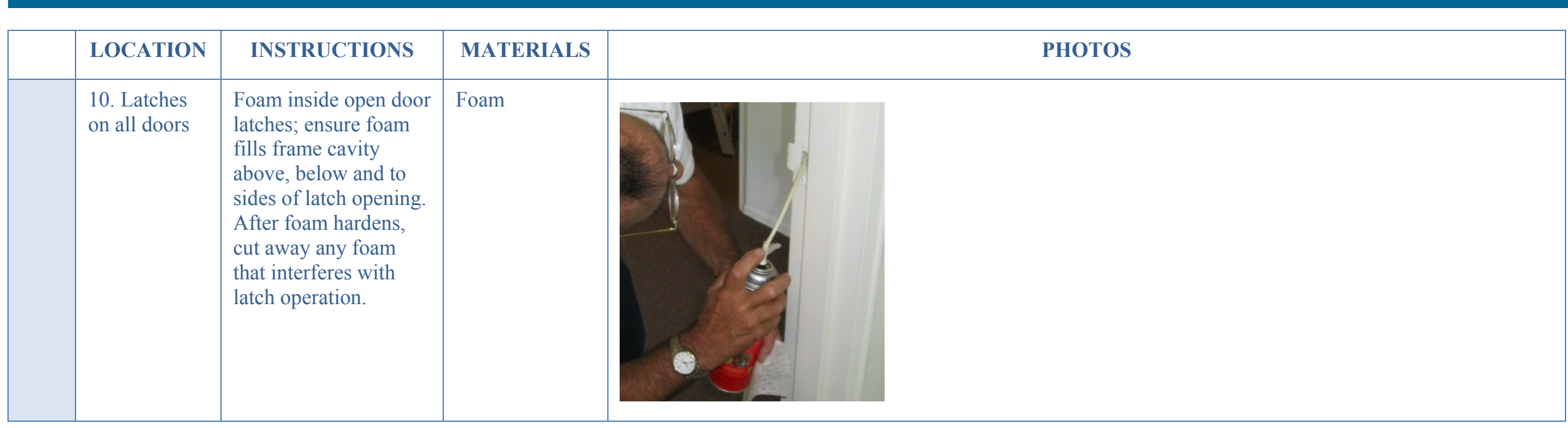


U.s. DEPARTMENT OF Energy Efficiency \&

ENERCY Renewable Energy

\begin{tabular}{|c|c|c|c|c|}
\hline & LOCATION & INSTRUCTIONS & MATERIALS & PHOTOS \\
\hline 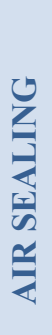 & $\begin{array}{l}\text { 11. Stair treads } \\
\text { and risers }\end{array}$ & $\begin{array}{l}\text { Caulk gaps around } \\
\text { risers, treads and } \\
\text { stringers and } \\
\text { between stringers } \\
\text { and wall when wall } \\
\text { is connected to } \\
\text { outside or } \\
\text { crawlspace. }\end{array}$ & Caulk & 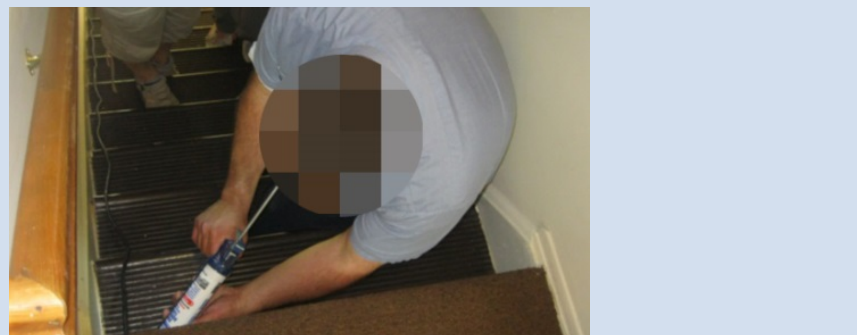 \\
\hline \multirow[b]{2}{*}{ U } & $\begin{array}{l}\text { 12. Mechanical } \\
\text { room door }\end{array}$ & $\begin{array}{l}\text { Replace louvered } \\
\text { door with solid } \\
\text { door with weather } \\
\text { stripping to seal } \\
\text { mechanical } \\
\text { equipment room } \\
\text { from conditioned } \\
\text { space. }\end{array}$ & $\begin{array}{l}\text { Solid door, } \\
\text { weather } \\
\text { stripping }\end{array}$ & Before: 1 \\
\hline & 13. Air handler & $\begin{array}{l}\text { Ensure that leaks } \\
\text { in air handler and } \\
\text { return ductwork } \\
\text { inside mechanical } \\
\text { room are well } \\
\text { sealed (including } \\
\text { around filter slot). }\end{array}$ & $\begin{array}{l}\text { Mastic and/or } \\
\text { foil tape }\end{array}$ & Well sealed: \\
\hline
\end{tabular}


U.s. DEPARTMENT OF $\mid$ Energy Efficiency \&

ENEY Renewable Energy

\begin{tabular}{|c|c|c|c|}
\hline $\begin{array}{l}\text { 14. Air handler } \\
\text { filter and grille }\end{array}$ & $\begin{array}{l}\text { Clean or replace } \\
\text { filter if dirty; clean } \\
\text { return air grille }\end{array}$ & $\begin{array}{l}\text { Vacuum or } \\
\text { compressed air; } \\
\text { replacement } \\
\text { filter; rags }\end{array}$ & \\
\hline
\end{tabular}


U.s. DEPARTMENT OF | Energy Efficiency \&

ENERCY Renewable Energy

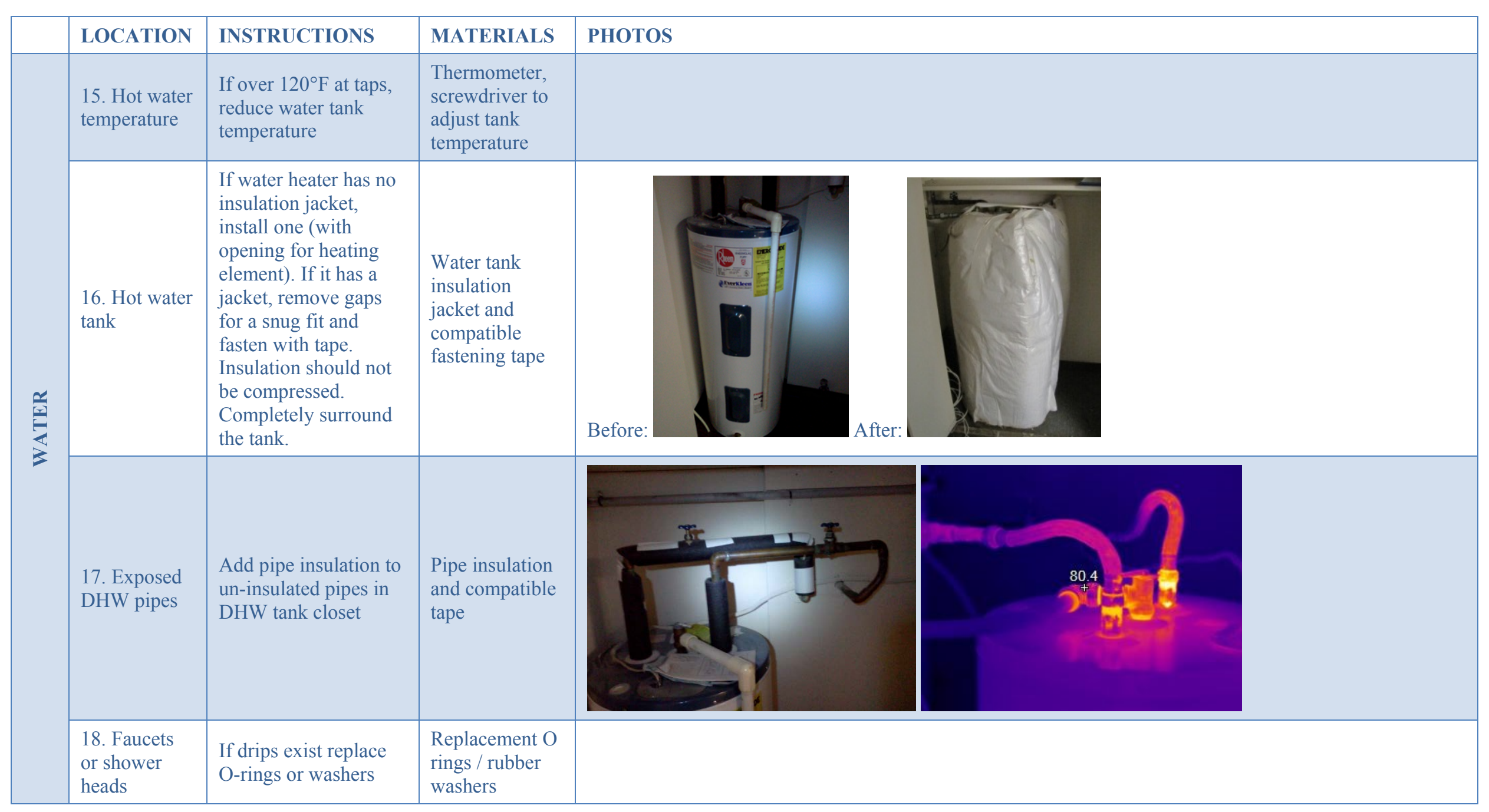


U.s. Department of | Energy Efficiency \&

ENERCY Renewable Energy

\begin{tabular}{|c|c|c|c|c|}
\hline & LOCATION & INSTRUCTIONS & MATERIALS & PHOTOS \\
\hline$\frac{1}{3}$ & $\begin{array}{l}\text { 19. Shower } \\
\text { head }\end{array}$ & $\begin{array}{l}\text { Ensure low-flow } \\
\text { showerhead installed - } \\
\text { if it takes less than } 20 \\
\text { seconds to fill a one } \\
\text { gallon container, } \\
\text { replace with low-flow } \\
\text { showerhead. }\end{array}$ & $\begin{array}{l}\text { Low-flow } \\
\text { shower head, } \\
\text { thread sealant / } \\
\text { compound }\end{array}$ & \\
\hline \multirow{2}{*}{ 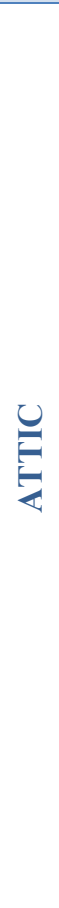 } & $\begin{array}{l}\text { 20. Attic } \\
\text { insulation } \\
\text { depth and } \\
\text { distribution }\end{array}$ & $\begin{array}{l}\text { Check that ceiling } \\
\text { insulation is dispersed } \\
\text { evenly without gaps, is } \\
\text { free of water damage, } \\
\text { and covers rafters and } \\
\text { other framing } \\
\text { members fully to the } \\
\text { exterior walls. Re- } \\
\text { arrange insulation or } \\
\text { supplement if } \\
\text { necessary. }\end{array}$ & $\begin{array}{l}\text { Flashlight, attic } \\
\text { insulation }\end{array}$ & Poor insulation condition: \\
\hline & $\begin{array}{l}\text { 21. Wall top } \\
\text { plates } \\
\text { intersection } \\
\text { with attic }\end{array}$ & $\begin{array}{l}\text { When/if replacing attic } \\
\text { insulation over framed } \\
\text { walls, foam } \\
\text { penetrations where } \\
\text { accessible. Also foam } \\
\text { wire penetrations in } \\
\text { top plates that are } \\
\text { within reach. }\end{array}$ & $\begin{array}{l}\text { Foam, } \\
\text { flashlight }\end{array}$ & Electrical penetration at top plate: \\
\hline
\end{tabular}


U.S. DEPARTMENT OF | Energy Efficiency \&

ENERCY Renewable Energy

\begin{tabular}{|c|c|c|c|c|}
\hline & LOCATION & INSTRUCTIONS & MATERIALS & PHOTOS \\
\hline \multirow{2}{*}{ 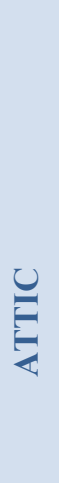 } & $\begin{array}{l}\text { 22. Attic } \\
\text { hatch } \\
\text { insulation }\end{array}$ & $\begin{array}{l}\text { Glue } 2 \text { " rigid foam to } \\
\text { back of hatch }\end{array}$ & $\begin{array}{l}\text { Rigid foam } \\
\text { board and } \\
\text { construction } \\
\text { adhesive }\end{array}$ & \\
\hline & $\begin{array}{l}\text { 23. Attic } \\
\text { hatch air } \\
\text { leakage }\end{array}$ & $\begin{array}{l}\text { Add gasket/weather } \\
\text { stripping to seal hatch } \\
\text { to opening }\end{array}$ & $\begin{array}{l}\text { Gasket or } \\
\text { weather } \\
\text { stripping }\end{array}$ & \\
\hline \multirow{2}{*}{$\stackrel{\mathscr{E}}{\underline{G}}$} & $\begin{array}{l}\text { 24. Light } \\
\text { bulbs }\end{array}$ & $\begin{array}{l}\text { Replace incandescent } \\
\text { bulbs with standard or } \\
\text { warm tone CFLs. }\end{array}$ & CFLs & \\
\hline & $\begin{array}{l}\text { 25. Pin-based } \\
\text { fluorescent } \\
\text { lamps }\end{array}$ & $\begin{array}{l}\text { Consider replacing with } \\
\text { LED when replacing } \\
\text { fixtures. }\end{array}$ & LED fixtures & \\
\hline
\end{tabular}


U.S. DEPARTMENT OF | Energy Efficiency \&

ENERCY Renewable Energy

\begin{tabular}{|c|c|c|c|c|}
\hline & LOCATION & INSTRUCTIONS & MATERIALS & РHOTOS \\
\hline \multirow{3}{*}{ 宸 } & $\begin{array}{l}\text { 26. Bath and } \\
\text { kitchen exhaust } \\
\text { fans (check } \\
\text { flow) }\end{array}$ & $\begin{array}{l}\text { Check fan flow. See } \\
\text { NYSERDA's } \\
\text { "Homeowner's Guide } \\
\text { to Ventilation" } \\
\text { (http://www.nyserda.n } \\
\text { y.gov/ / media/Files/E } \\
\text { ERPPResidential/hom } \\
\text { e vent guide.pdf?sc } \\
\text { database=web) }\end{array}$ & $\begin{array}{l}\text { See NYSERDA } \\
\text { guide (attached) }\end{array}$ & \\
\hline & $\begin{array}{l}\text { 27. Bath and } \\
\text { kitchen exhaust } \\
\text { fans (check } \\
\text { grime build-up) }\end{array}$ & $\begin{array}{l}\text { If excessively dirty, } \\
\text { vacuum fan blades, } \\
\text { motor, and housing } \\
\text { (wipe with rag before } \\
\text { air sealing) }\end{array}$ & Vacuum, rags & \\
\hline & $\begin{array}{l}\text { 28. Bath and } \\
\text { kitchen exhaust } \\
\text { fans (check } \\
\text { condition) }\end{array}$ & $\begin{array}{l}\text { If fan makes irregular } \\
\text { mechanical noises, } \\
\text { then replace }\end{array}$ & $\begin{array}{l}\text { Replacement } \\
\text { exhaust fan }\end{array}$ & \\
\hline
\end{tabular}




\section{Appendix E: Philadelphia Housing Authority Implementation Guidelines}

\section{Philadelphia Housing Authority: Energy Efficiency Turnover Checklist}

Address and apartment number:

\begin{tabular}{|c|c|c|c|c|}
\hline & ITEM & APPLICABLE SITES & COMPLETE & $\mathbf{N} / \mathbf{A}$ \\
\hline \multirow{6}{*}{ 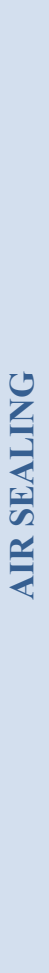 } & $\begin{array}{l}\text { Sample units to check that air flow is not near } \\
\text { lower allowable limit according to ASHRAE 62- } \\
89 \text { unless mechanical ventilation is planned. If } \\
\text { planning to tighten units housing combustion } \\
\text { equipment, consult with qualified personnel to } \\
\text { confirm that NFPA-54 standards are met and that } \\
\text { combustion appliances are supplied with } \\
\text { adequate combustion and dilution air and are } \\
\text { vented properly }\end{array}$ & \multirow{6}{*}{$\begin{array}{l}\text { RICHARD ALLEN I \& } \\
\text { II } \\
\text { GRAYS FERRY } \\
\text { BARTRAM HOMES } \\
\text { MORTON HOMES }\end{array}$} & & \\
\hline & $\begin{array}{l}\text { Seal bottom of walls to floor if carpet removed } \\
\text { and/or where accessible }\end{array}$ & & & \\
\hline & $\begin{array}{l}\text { Seal plumbing penetrations (all walls): shower } \\
\text { heads, under sinks, water heater }\end{array}$ & & & \\
\hline & $\begin{array}{l}\text { Seal electrical penetrations (all walls, ceilings): } \\
\text { outlets, switches, behind oven/fridge, telephone } \\
\text { box, intercom, in closet ceilings/floors }\end{array}$ & & & \\
\hline & Seal ceiling penetrations at lighting fixtures & & & \\
\hline & $\begin{array}{l}\text { Replace entry door weather stripping if } \\
\text { necessary. Caulk around entry door frame and } \\
\text { windows }\end{array}$ & & & \\
\hline \multirow{4}{*}{ 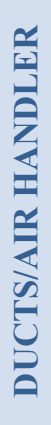 } & $\begin{array}{l}\text { Seal exhaust fan housing and duct boots to } \\
\text { ceiling }\end{array}$ & $\begin{array}{l}\text { RICHARD ALLEN I \& } \\
\text { II } \\
\text { GRAYS FERRY } \\
\text { MORTON HOMES }\end{array}$ & & \\
\hline & Seal all air handler cabinets and return ductwork & $\begin{array}{l}\text { ALL WITH AIR } \\
\text { HANDLERS }\end{array}$ & & \\
\hline & Change or clean filter & ALL WITH DUCTS & & \\
\hline & Clean ductwork & ALL WITH DUCTS & & \\
\hline \multirow{2}{*}{$\frac{1}{3}$} & $\begin{array}{l}\text { Check and adjust hot water temperature (120 } \\
\text { degrees Fahrenheit) }\end{array}$ & ALL & & \\
\hline & Insulate exposed DHW pipes & ALL & & \\
\hline \multirow{2}{*}{$\stackrel{U}{E}$} & Check and fix attic insulation & RICHARD ALLEN II & & \\
\hline & Add attic hatch insulation and gasket & RICHARD ALLEN II & & \\
\hline
\end{tabular}




\begin{tabular}{|c|l|l|l|l|}
\hline & ITEM & APPLICABLE SITES & COMPLETE & N/A \\
\hline \multirow{2}{*}{$\begin{array}{l}\text { Clean bath and kitchen exhaust fans } \\
\text { RICHARD ALLEN I } \\
\text { AND II } \\
\text { MORTON HOMES }\end{array}$} & & \\
\cline { 2 - 5 } & $\begin{array}{l}\text { Replace incandescent and/or fluorescent lighting } \\
\text { with CFLs }\end{array}$ & ALL & & \\
\cline { 2 - 5 } & $\begin{array}{l}\text { Equipment inspection completed - see page 2. If } \\
\text { any items are checked YES, refer for } \\
\text { maintenance. }\end{array}$ & ALL & & \\
\hline
\end{tabular}

Signature of responsible staff:

Name:

Date completed: 


\section{Philadelphia Housing Authority: Energy Efficiency Turnover Guidelines}

The following guidelines are intended for use when apartments are prepared for new residents. All activities are intended to be lowcost, achievable by PHA staff with readily available tools and materials, and fit within the time available during unit turnover. The guidelines are organized by topic and include information on location, how to accomplish the task, materials required and photos illustrating typical conditions

\begin{tabular}{|c|c|c|c|c|}
\hline & LOCATION & INSTRUCTIONS & MATERIALS & PHOTOS \\
\hline \multirow[t]{2}{*}{ 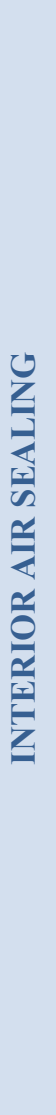 } & $\begin{array}{l}\text { 1. Bottom of } \\
\text { walls }\end{array}$ & $\begin{array}{l}\text { In rooms without } \\
\text { carpet, caulk } \\
\text { bottom of wall to } \\
\text { floor and/or base } \\
\text { molding (may } \\
\text { require removal } \\
\text { and replacement of } \\
\text { vinyl cove). If } \\
\text { replacing carpet, } \\
\text { caulk between } \\
\text { bottom of wall and } \\
\text { floor before new } \\
\text { carpet is installed. } \\
\text { Seal around } \\
\text { baseboard heaters } \\
\text { with caulk suitable } \\
\text { for high } \\
\text { temperatures. }\end{array}$ & $\begin{array}{l}\text { Caulk, cove } \\
\text { molding and } \\
\text { adhesive }\end{array}$ & \\
\hline & $\begin{array}{l}\text { 2. Plumbing } \\
\text { penetrations } \\
\text { at walls and } \\
\text { floor }\end{array}$ & $\begin{array}{l}\text { Foam-seal } \\
\text { plumbing } \\
\text { penetrations where } \\
\text { accessible; open } \\
\text { plumbing access } \\
\text { panels and seal } \\
\text { where pipes } \\
\text { penetrate through } \\
\text { floor }\end{array}$ & Foam & \\
\hline
\end{tabular}




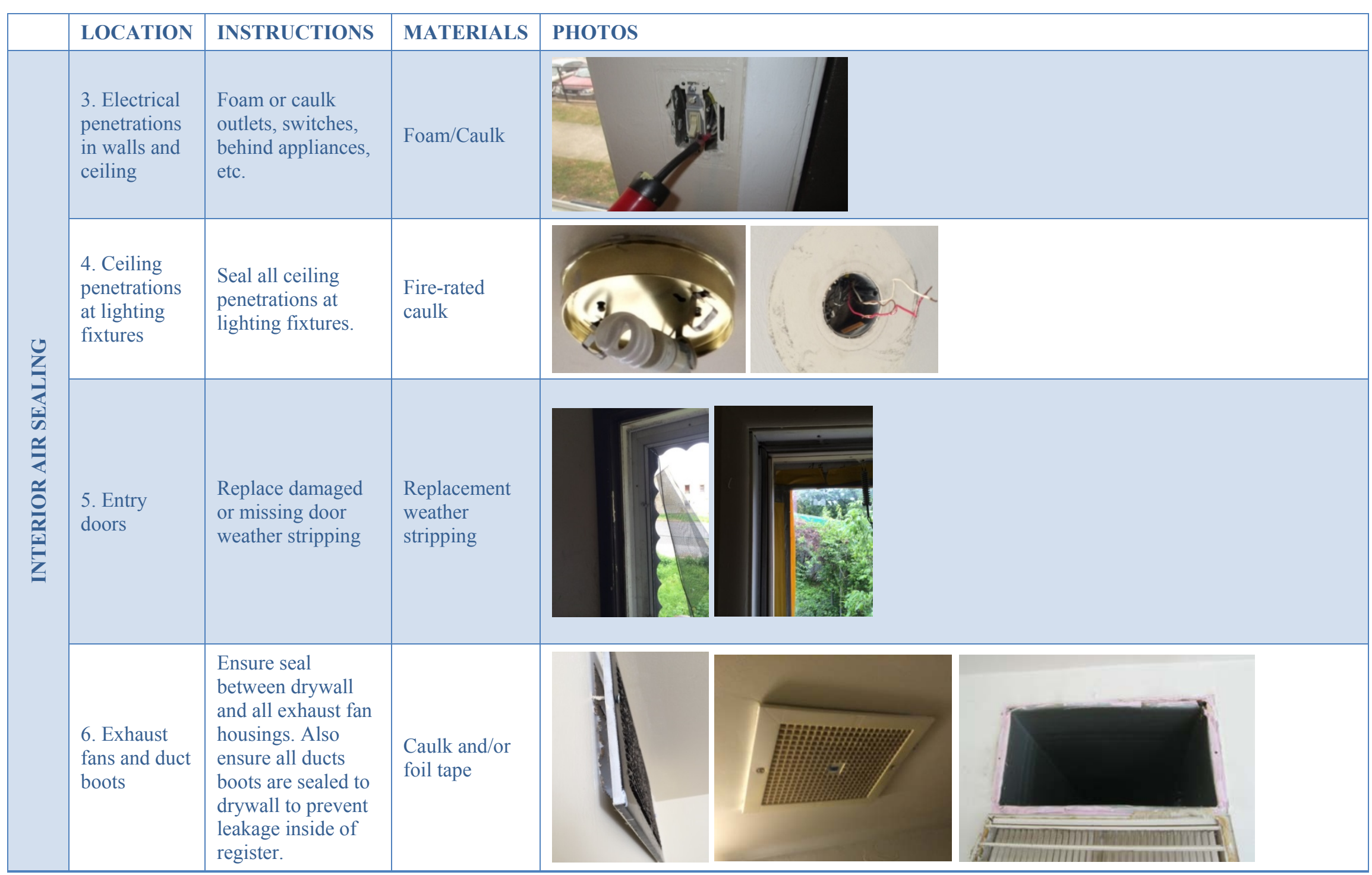




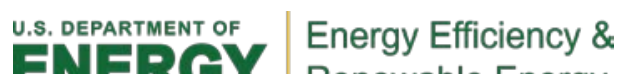

ENERCY Renewable Energy

\begin{tabular}{|l|l|l|l|}
\hline LOCATION & INSTRUCTIONS & MATERIALS & PHOTOS \\
\hline 7. Air \\
handler & $\begin{array}{l}\text { Ensure that leaks in } \\
\text { air handler and } \\
\text { return ductwork } \\
\text { inside mechanical } \\
\text { room are well } \\
\text { sealed (including } \\
\text { around filter slot). }\end{array}$ & $\begin{array}{l}\text { Fire-rated foil } \\
\text { tape or caulk } \\
\text { or low- } \\
\text { expansion } \\
\text { foam }\end{array}$ \\
\hline 8. Air & $\begin{array}{l}\text { Change or clean } \\
\text { hilter as appropriate }\end{array}$ & $\begin{array}{l}\text { New } \\
\text { compatible air } \\
\text { handler filter }\end{array}$ \\
\hline 9. Ducts & $\begin{array}{l}\text { Remover register } \\
\text { covers and inspect } \\
\text { inside ductwork. If } \\
\text { large amounts of } \\
\text { dust or debris exist } \\
\text { or signs of vermin, } \\
\text { clear debris and } \\
\text { clean ducts If } \\
\text { suspected mold is } \\
\text { present, have } \\
\text { inspected by } \\
\text { qualified individual } \\
\text { and remediated if } \\
\text { necessary. }\end{array}$ & $\begin{array}{l}\text { Vacuum } \\
\text { cleaner with } \\
\text { HEPA filter. } \\
\text { Do not use } \\
\text { water or } \\
\text { chemical } \\
\text { biocides in } \\
\text { ductwork. }\end{array}$ \\
\hline
\end{tabular}




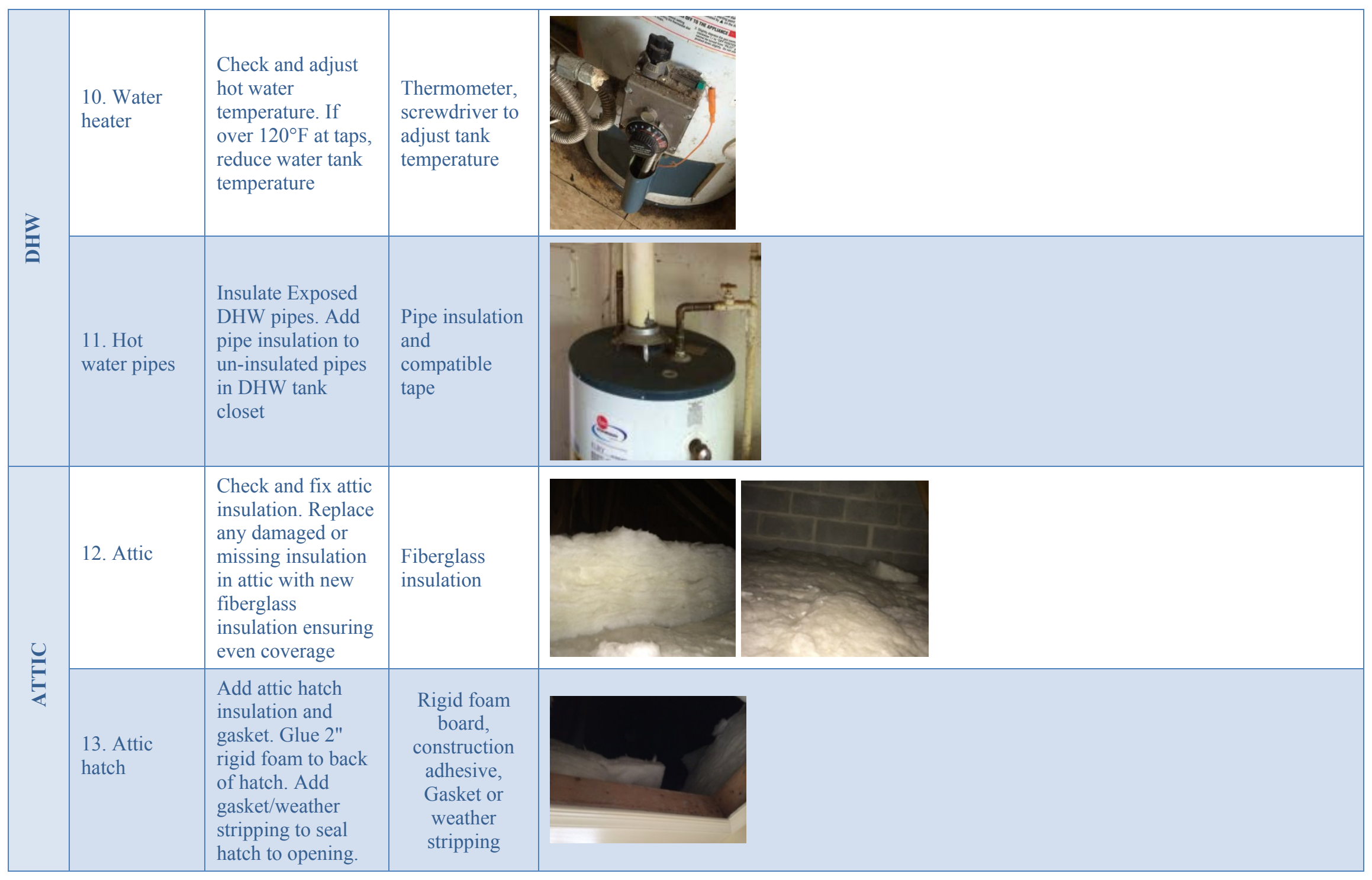




\section{U.S. DEFARTMENT OF Energy Efficiency \&}

ENERCY Renewable Energy

\begin{tabular}{|l|l|l|l|l|}
\hline $\begin{array}{l}\text { 14. Exhaust } \\
\text { fan }\end{array}$ & $\begin{array}{l}\text { Clean bath and } \\
\text { kitchen exhaust } \\
\text { fans. If dirty, } \\
\text { vacuum fan } \\
\text { blades, motor, } \\
\text { and housing } \\
\text { (wipe with rag } \\
\text { before air } \\
\text { sealing). }\end{array}$ \\
\hline $\begin{array}{l}\text { Replace } \\
\text { incandescent } \\
\text { bulbs with new } \\
\text { CFL bulbs. }\end{array}$ & CFL bulbs \\
\hline
\end{tabular}




\section{Philadelphia Housing Authority: Equipment Assessment}

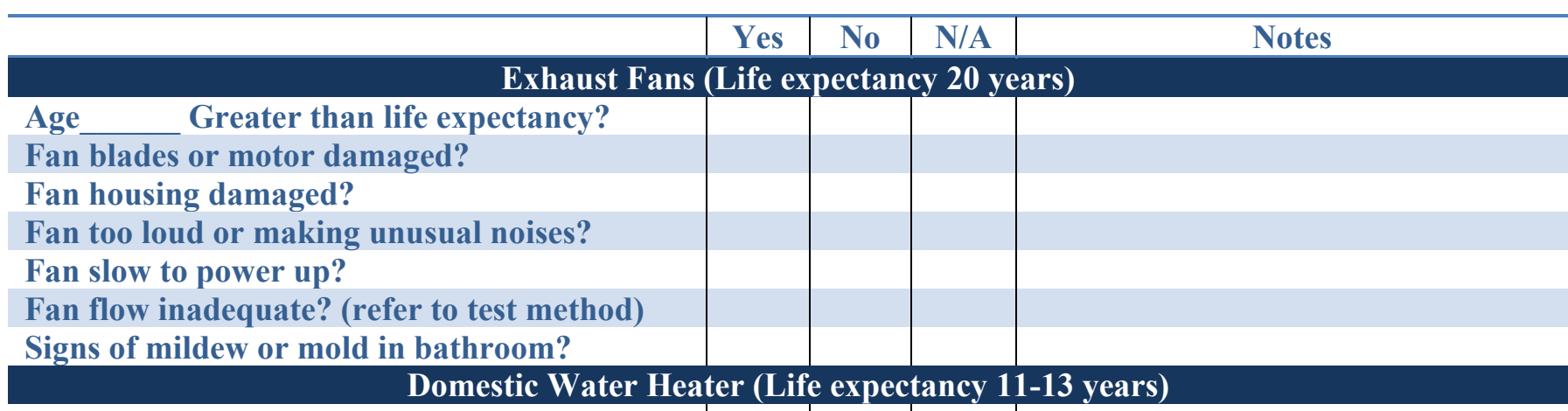

Age Greater than life expectancy?

Signs of leakage (rust, pooling stains, etc.)?

Water and gas piping corrosion?

Flue shows signs of soot or flashback (black streaks)?

Ignition components show signs of flashback?

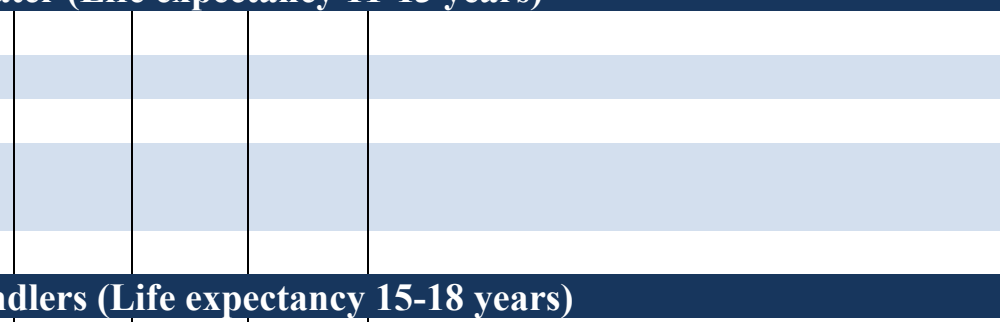

Age

Furnaces and Air Handlers (Life expectancy 15-18 years)

Heat exchanger has visible cracks, soot at duct registers, burners, etc.)

Vent connection and chimney shows damage?

Fan blower has cracked rusted or bent blades?

\section{Duct systems (Life expectancy 27-40 years)}

Age__ Greater than life expectancy?

Ducts show signs of leakage (holes, cracks, etc.)

Duct registers show signs of damage and/or signs of soot and mildew

With system running, some registers lack flow?

Hydronic Heating systems (Life expectancy 20-25 years)

Age__ Greater than life expectancy?

Distribution pipes and fittings show signs of corrosion/damage?

Baseboards radiators have bent fins or other signs of damage?

Radiators lack controls?

\section{Central Air Conditioning (Life expectancy 15 years)}

Age Greater than life expectancy?

Compressor blades cracked, bent or rusted?

Refrigerant lines lack insulation?

Evaporator coil in air handler shows physical damage, corrosion or frost?

Condensate line shows signs of leakage or damage?

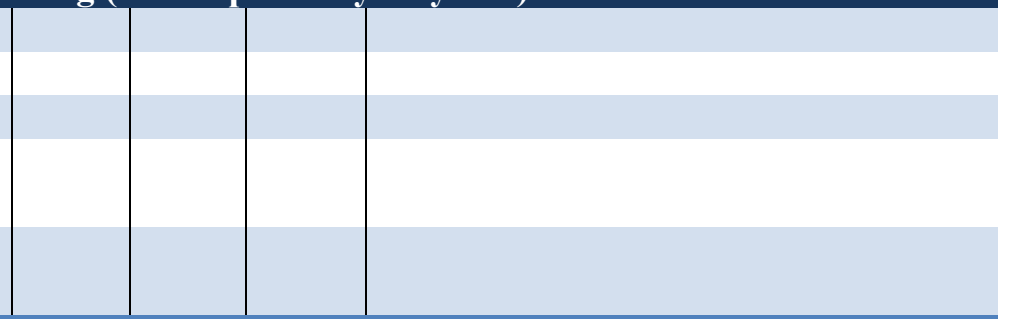

\section{If Any Items are Checked YES, Refer for Maintenance}




\section{Appendix F: Norwalk Housing Authority Implementation Guidelines}

Norwalk Housing Authority: Energy Efficiency Turnover Checklist

Address and unit number:

\begin{tabular}{|c|c|c|c|}
\hline & ITEM & COMPLETE & N/A \\
\hline \multirow{7}{*}{ 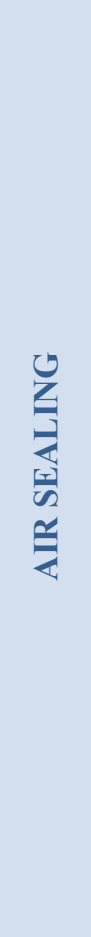 } & $\begin{array}{l}\text { Sample units to check that air flow is not near lower } \\
\text { allowable limit according to ASHRAE } 62-89 \text { unless } \\
\text { mechanical ventilation is planned. If planning to tighten units } \\
\text { housing combustion equipment, consult with qualified } \\
\text { personnel to confirm that NFPA- } 54 \text { standards are met and } \\
\text { that combustion appliances are supplied with adequate } \\
\text { combustion and dilution air and are vented properly }\end{array}$ & & \\
\hline & $\begin{array}{l}\text { Seal bottom of walls to floor if carpet/cove molding removed } \\
\text { and/or where accessible }\end{array}$ & & \\
\hline & $\begin{array}{l}\text { Seal plumbing penetrations (all walls): shower heads, under } \\
\text { sinks, water heater, etc. }\end{array}$ & & \\
\hline & $\begin{array}{l}\text { Seal electrical penetrations (all walls, ceilings): outlets, } \\
\text { switches, behind oven/fridge, telephone box, intercom, in } \\
\text { closet ceilings/floors }\end{array}$ & & \\
\hline & $\begin{array}{l}\text { If entering attic, seal wall top plates and wire penetrations } \\
\text { within reach in attic, if accessible }\end{array}$ & & \\
\hline & Foam inside door latches (hollow metal door frames only) & & \\
\hline & $\begin{array}{l}\text { Replace door weather stripping if worn or missing (including } \\
\text { unconditioned basements) }\end{array}$ & & \\
\hline \multirow{2}{*}{ 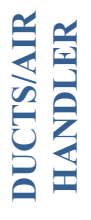 } & Seal duct boots to ceiling/floor & & \\
\hline & $\begin{array}{l}\text { Seal all air handler cabinet and exposed ductwork seams } \\
\text { (where ducts exist), especially in basements and attics, } \\
\text { preferably with mastic }\end{array}$ & & \\
\hline \multirow{4}{*}{$\frac{n}{2}$} & $\begin{array}{l}\text { Check and adjust hot water temperature (120 degrees } \\
\text { Fahrenheit) }\end{array}$ & & \\
\hline & Insulate electric hot water tank & & \\
\hline & Insulate exposed DHW pipes & & \\
\hline & $\begin{array}{l}\text { Check shower flow and install low-flow showerhead, if } \\
\text { necessary }\end{array}$ & & \\
\hline \multirow{2}{*}{$\underset{Z}{E}$} & Check and fix attic insulation & & \\
\hline & Add attic hatch insulation and gasket & & \\
\hline
\end{tabular}




\begin{tabular}{|l|l|l|l|}
\hline & ITEM & COMPLETE & N/A \\
\hline & $\begin{array}{l}\text { Clean bath and kitchen exhaust fans and seal exhaust fan } \\
\text { housing to ceiling }\end{array}$ & & \\
\hline & $\begin{array}{l}\text { Equipment inspection completed - see page 2. If any items } \\
\text { are checked YES, refer for maintenance. }\end{array}$ & & \\
\hline
\end{tabular}

A note about air sealing: If the dwelling unit has natural or induced draft combustion appliances, precautions need to be taken to ensure that air sealing the dwelling does not create an unsafe situation such as backdrafting. It is best to seek the advice of an energy professional that can perform a combustion safety test before proceeding with air sealing.

Date completed:

Signature of responsible staff:

Name: 


\section{Norwalk Housing Authority: Energy Efficiency Turnover Guidelines}

The following guidelines are intended for use when apartments are prepared for new residents. All activities are intended to be low-cost, achievable by PHA staff with readily available tools and materials, and fit within the time available during unit turnover. The guidelines are organized by topic and include information on location, how to accomplish the task, materials required and photos illustrating typical conditions

\begin{tabular}{|c|c|c|c|c|}
\hline & LOCATION & INSTRUCTIONS & MATERIALS & PHOTOS \\
\hline & $\begin{array}{l}\text { 1. Bottom of } \\
\text { walls }\end{array}$ & $\begin{array}{l}\text { In rooms without carpet, } \\
\text { caulk bottom of wall to } \\
\text { floor and/or base } \\
\text { molding (may require } \\
\text { removal and } \\
\text { replacement of vinyl } \\
\text { cove). If replacing } \\
\text { carpet, caulk between } \\
\text { bottom of wall and floor } \\
\text { before new carpet is } \\
\text { installed. Seal around } \\
\text { baseboard heaters with } \\
\text { caulk suitable for high } \\
\text { temperatures. }\end{array}$ & $\begin{array}{l}\text { Caulk, cove } \\
\text { molding and } \\
\text { adhesive }\end{array}$ & \\
\hline 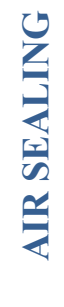 & $\begin{array}{l}\text { 2. Plumbing } \\
\text { penetrations at } \\
\text { walls and floor }\end{array}$ & $\begin{array}{l}\text { Foam-seal plumbing } \\
\text { penetrations in walls and } \\
\text { floors where accessible; }\end{array}$ & Foam & \\
\hline & $\begin{array}{l}\text { 3. Electrical } \\
\text { penetrations in } \\
\text { walls and } \\
\text { ceiling }\end{array}$ & $\begin{array}{l}\text { Foam large penetrations } \\
\text { at lights and behind } \\
\text { appliances; caulk outlets, } \\
\text { switches between box } \\
\text { and wall opening }\end{array}$ & Foam/caulk & \\
\hline
\end{tabular}




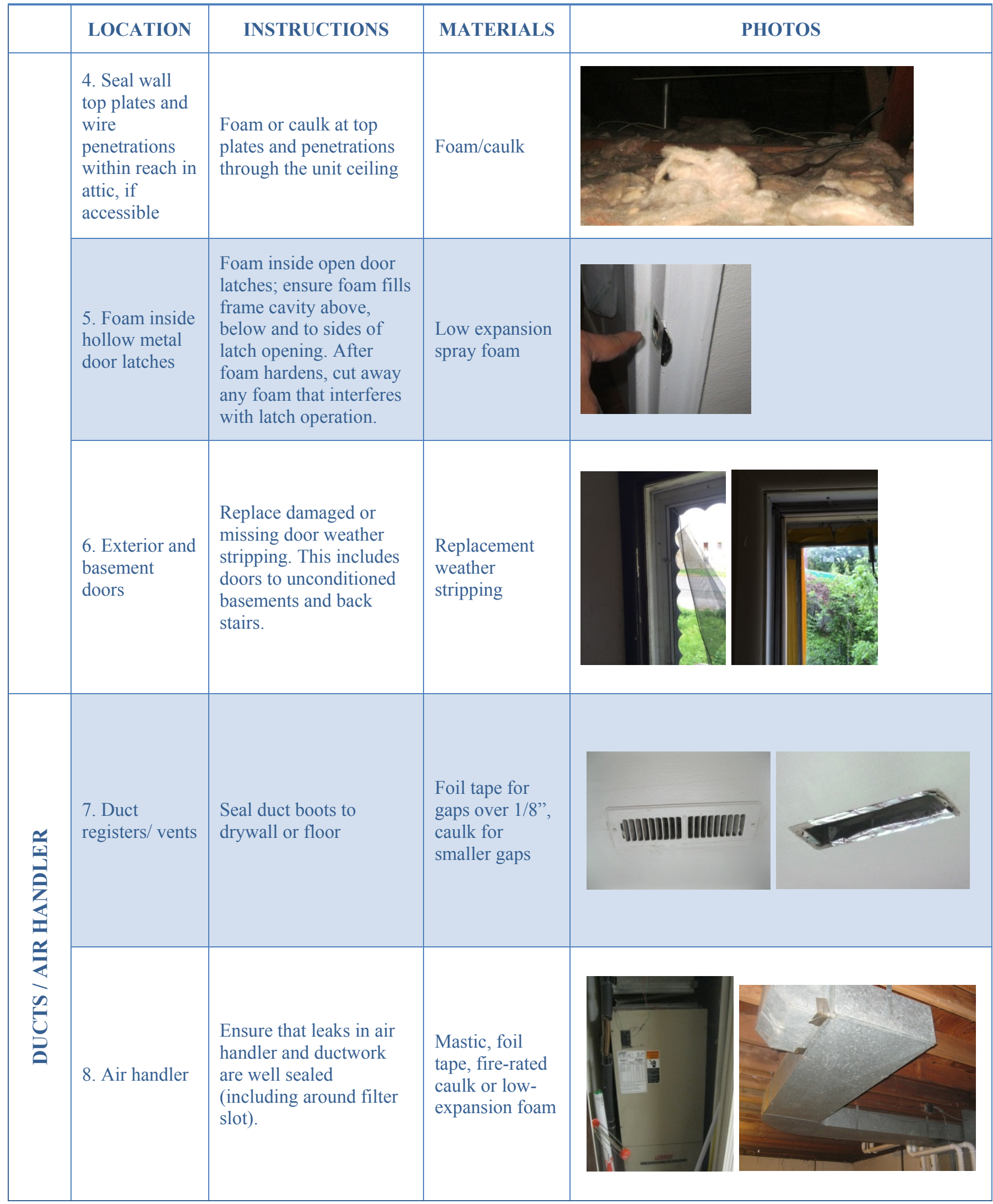




\begin{tabular}{|c|c|c|c|c|}
\hline & LOCATION & INSTRUCTIONS & MATERIALS & PHOTOS \\
\hline \multirow{4}{*}{$\begin{array}{l}0 \\
2 \\
2 \\
2 \\
2\end{array}$} & $\begin{array}{l}\text { 9. Water } \\
\text { heater }\end{array}$ & $\begin{array}{l}\text { Check and adjust hot } \\
\text { water temperature. If } \\
\text { over } 120^{\circ} \mathrm{F} \text { at taps, } \\
\text { reduce water tank } \\
\text { temperature. }\end{array}$ & $\begin{array}{l}\text { Thermometer, } \\
\text { screwdriver to } \\
\text { adjust tank } \\
\text { temperature }\end{array}$ & \\
\hline & $\begin{array}{l}\text { 10. Insulate } \\
\text { electric hot } \\
\text { water tank }\end{array}$ & $\begin{array}{l}\text { If hot water heater does } \\
\text { not have an insulation } \\
\text { jacket installed, install } \\
\text { one. If it does have a } \\
\text { jacket installed, remove } \\
\text { air gaps for a snug fit } \\
\text { and fasten with tape. } \\
\text { Insulation should be free } \\
\text { of air gaps but not } \\
\text { compressed. Attempt to } \\
\text { completely surround the } \\
\text { tank. }\end{array}$ & $\begin{array}{l}\text { Insulation } \\
\text { blanket, tape }\end{array}$ & \\
\hline & $\begin{array}{l}\text { 11. Hot water } \\
\text { pipes }\end{array}$ & $\begin{array}{l}\text { Insulate exposed DHW } \\
\text { pipes. Standard size at } \\
\text { NHA appears to be } 3 / 4^{“ "} \\
\text { copper pipes. }\end{array}$ & $\begin{array}{l}\text { Pipe insulation } \\
\text { and compatible } \\
\text { tape }\end{array}$ & \\
\hline & $\begin{array}{l}\text { 12. Low-flow } \\
\text { showerheads }\end{array}$ & $\begin{array}{l}\text { Test flow of } \\
\text { showerheads, and } \\
\text { replace high-flow } \\
\text { fixtures with low } \\
\text { fixtures. If it takes less } \\
\text { than } 20 \text { seconds to fill a } \\
\text { one gallon container, } \\
\text { replace with low-flow } \\
\text { showerhead. }\end{array}$ & $\begin{array}{l}\text { Low-flow } \\
\text { showerheads, } \\
\text { flow bag or } \\
\text { marked bucket } \\
\text { and timer }\end{array}$ & \\
\hline
\end{tabular}




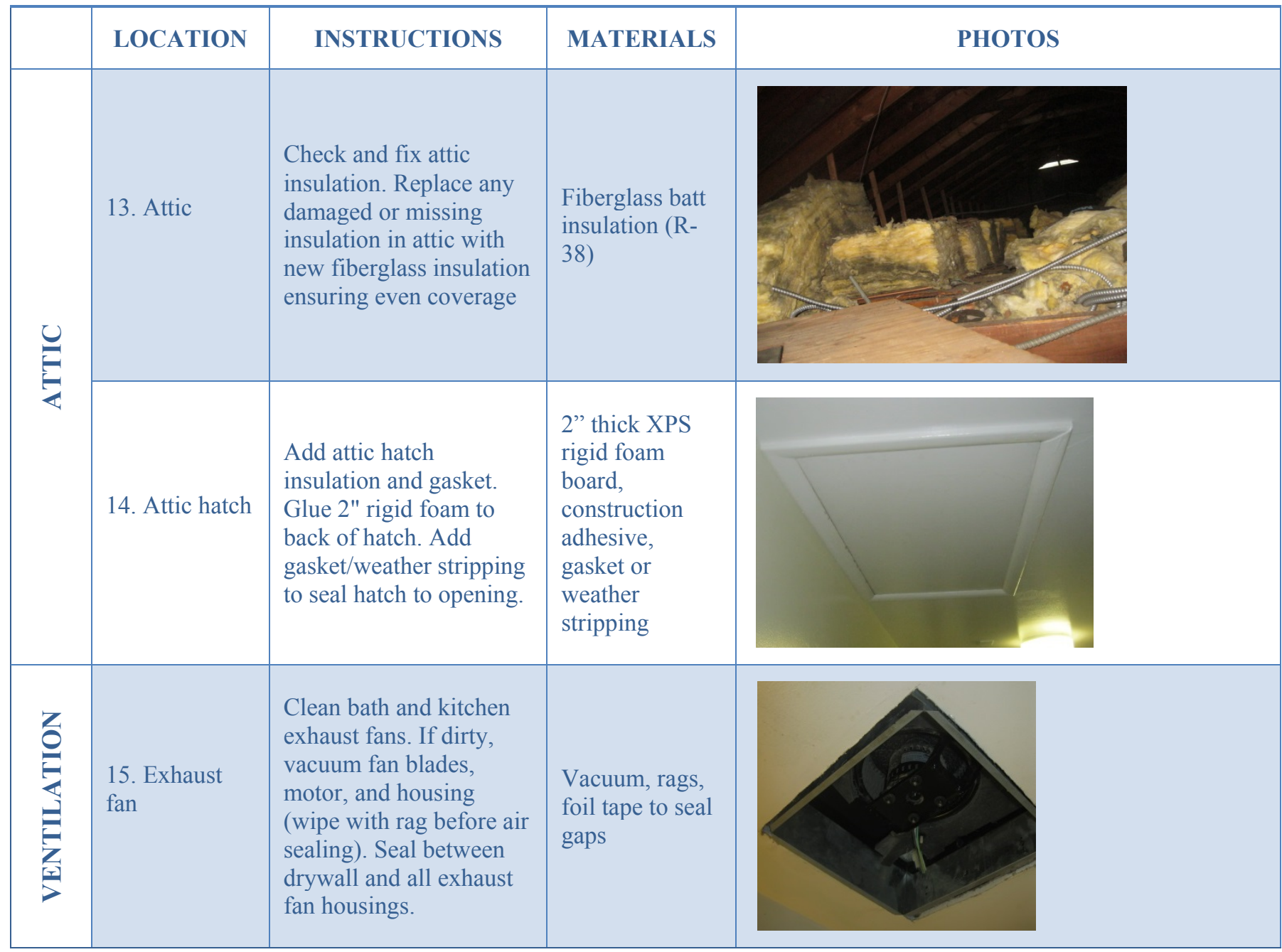


